NBER WORKING PAPER SERIES

\title{
GOING THE EXTRA MILE: DISTANT LENDING AND CREDIT CYCLES
}

\author{
João Granja \\ Christian Leuz \\ Raghuram Rajan \\ Working Paper 25196 \\ http://www.nber.org/papers/w25196 \\ NATIONAL BUREAU OF ECONOMIC RESEARCH \\ 1050 Massachusetts Avenue \\ Cambridge, MA 02138 \\ October 2018, Revised May 2021
}

\begin{abstract}
We thank Ray Ball, Jan Bouwens, Giovanni Dell'Ariccia (discussant), Florian Heider (discussant), Anil Kashyap, Randall Kroszner, Stefan Nagel, Steven Ongena (discussant), Amit Seru, Doug Skinner, Philipp Schnabl (discussant), Eric So, Wei Xiong (editor), Anastasia Zakolyukina, Luigi Zingales, two anonymous reviewers and an associate editor, as well as the workshop participants at the 2020 AFA meetings, Chicago Booth, CUHK, European Finance Association Annual Meeting, Harvard Business School, Erasmus University, University of Hong Kong, Labex ReFi, Paris, 8th MoFir Banking Workshop, NBER Corporate Finance, New York University, University of Amsterdam, University of British Columbia, Universidade do Minho, the University of Pennsylvania, and the University of Toronto for their helpful comments and suggestions. We thank Fabian Nagel and Igor Kuznetsov for excellent research assistance. The views expressed herein are those of the authors and do not necessarily reflect the views of the National Bureau of Economic Research.
\end{abstract}

NBER working papers are circulated for discussion and comment purposes. They have not been peer-reviewed or been subject to the review by the NBER Board of Directors that accompanies official NBER publications.

(C) 2018 by João Granja, Christian Leuz, and Raghuram Rajan. All rights reserved. Short sections of text, not to exceed two paragraphs, may be quoted without explicit permission provided that full credit, including $\odot$ notice, is given to the source. 
Going the Extra Mile: Distant Lending and Credit Cycles

João Granja, Christian Leuz, and Raghuram Rajan

NBER Working Paper No. 25196

October 2018, Revised May 2021

JEL No. E32,E44,G01,G18,G21,G32,L14

\begin{abstract}
$\underline{\text { ABSTRACT }}$
The average distance of U.S. banks from their small corporate borrowers increased before the global financial crisis, especially for banks in competitive counties. Small distant loans are harder to make, so loan quality deteriorated. Surprisingly, such lending intensified as the Fed raised interest rates from 2004. Why? We show banks' responses to higher rates led to bank deposits shifting into competitive counties. Short-horizon bank management recycled these inflows into risky loans to distant uncompetitive counties. Thus, rate hikes, competition, and managerial shorttermism explain why inflows 'burned a hole' in banks' pockets and, more generally, increased risky lending.

João Granja

Booth School of Business

University of Chicago

5807 S. Woodlawn Avenue

Chicago, IL 60637-1610

joaogranja@chicagobooth.edu

Christian Leuz

Booth School of Business

University of Chicago

5807 S. Woodlawn Avenue

Chicago, IL 60637-1610

and NBER

cleuz@chicagobooth.edu

Raghuram Rajan

Booth School of Business

University of Chicago

5807 South Woodlawn Avenue

Chicago, IL 60637

and NBER

raghuram.rajan@ChicagoBooth.edu
\end{abstract}


Descriptions of financial frenzies suggest lenders abandon caution in the midst of a boom and become more aggressive (or careless) in their lending (see, e.g., Aliber and Kindleberger, 2017; Minsky and Kaufman, 2008). A number of studies (e.g., Giannetti and Laeven, 2012; Maddaloni and Peydró, 2010; Mian and Sufi, 2009; Lisowsky, Minnis, and Sutherland, 2017; Rajan and Ramcharan, 2015) show that lenders' credit standards are procyclical. However, not all expansions turn into frenzies, lenders do not become uniformly exuberant in a frenzy across all regions or sectors in a country, and not all lenders within each region behave in the same way. This paper examines the bank lending boom and bust in the financial crisis of 2007-2009, trying to understand why lending took off when it did, where it was most pronounced, and what characterized the banks that were most prone to it.

We examine these issues using a simple and accessible proxy for risk taking - the extent to which lenders are willing to expand their loan portfolio by lending to small borrowers at a greater physical distance from their branches. A large theoretical and empirical literature suggests that banks add value through their special ability to screen and monitor loans based on the private information they collect about current and prospective clients (e.g., Diamond, 1984, 1991; James, 1987). This ability to produce information about hard to evaluate credits has historically been based on close interactions between bankers and potential borrowers (e.g., Berger and Udell, 1995; Liberti and Petersen, 2019: Petersen and Rajan, 1994). As Stein (2002) suggests, "soft" information such as the firmness of a borrower's handshake, the cleanliness of her premises, or her punctuality in meetings might all reveal valuable information about the likelihood of repayment. Petersen and Rajan (2002) show, however, that the adoption of information and credit scoring technologies in the 1980s and 1990s brought fundamental changes to banks' business models. Slowly but steadily, information and communication technologies allowed lenders to substitute somewhat for local interactions in lending to small businesses. Hence, the average distance between banks and their borrowers grew steadily as these technologies improved.

Yet, at any point in time, available technologies determine the limits of the area within which a bank can lend safely. If a bank stretches to lend beyond these limits, it will screen and monitor the borrower less effectively and, thus, take on more credit risk. Therefore, a faster-than-trend expansion of the average lending distance is either evidence of a rapid improvement of technology or suggestive of increased bank risk taking. If it reflects risk taking and not simply more rapid innovation, we should see that the more distant loans, especially those made during a boom, are associated with higher default rates. A rapid drop in average distance in the bust should also follow such risk taking as banks become more conservative in lending.

One key contribution of this paper is to establish that in the episode we examine, an abovetrend increase in lending distance is indeed a manifestation of, and a valid proxy for, risk taking. Thereafter, we examine the circumstances in which such risk taking is exacerbated. Finally, we suggest an explanation of when, where, and by which banks risk is taken, and offer evidence supporting this explanation.

Our analysis uses data on small business loans originated in the United States over the last two 
decades. Specifically, we use the Community Reinvestment Act (CRA) dataset, which stratifies the annual volume of loans originated by banks with total assets above $\$ 1$ billion by the county of the loan recipient. We combine the CRA dataset with the Summary of Deposits (SOD) dataset, which provides information on the branch networks of all commercial banks operating in the U.S. This combination allows us to compute measures of the physical distance between the county of loan recipients and the closest branch of their bank lender 1

We find that the long-run trend toward greater average distances between banks and their borrowers, initially documented by Petersen and Rajan (2002), persists in the past 20 years. Importantly, however, we uncover a significant cyclical component in the evolution of lending distances. Distances widen considerably in boom periods and then shorten again during the ensuing downturns. Between 2004 and 2007, banks increased their average distances from 175 miles to 350 miles. These distances, however, quickly slipped back to approximately 200 miles following the 2008 financial crisis.

This cyclical pattern in lending distances is observed after the inclusion of (borrower) countyyear fixed effects and bank fixed effects. As the former accounts for loan demand in a county at a point in time, the results imply that, in booms, distant banks increase their lending to borrowers in a county relative to nearby banks, and do so more than in down years. Put differently, the results cannot be explained by differences in loan demand growth across counties. Since we also correct for bank-specific effects, it cannot be explained by changes in the composition of lenders in the economy over the cycle. Distance cyclicality also exists when we examine other points of the lending-distance distribution, such as the median. We further confirm that the effect can be seen in banks of different size classes. To address the concern that changes in the nature of borrowers or loans over the cycle may drive the results, we show the effect also exists within a specific borrower sector.

The next step is to establish that distant lending in the boom is, on average, riskier and hence amounts to additional risk taking by the banks. Towards this end, we use the Small Business Administration (SBA) loan-level dataset of government-guaranteed loans, which contains information on ex-post defaults or charge-offs (as we unfortunately do not have default data for small business loans in the CRA dataset). We find that distant loans are significantly more likely to be charged-off relative to other loans issued by banks closer to their borrowers in the same county during the same years. This sensitivity of charge-offs to distance is more pronounced for loans originated in the pre-crisis boom years. Specifically, a one-percent increase in lending distance in 2006 and 2007 is associated with an increase in the charge-off probability that is between two and three times larger than that of a similar increase in lending distances in 2003. Furthermore, we find little evidence that banks obtain compensation through higher interest rates for the additional risks of lending at a greater distance. Our results suggest that, if anything, the sensitivity of loan interest rates to distance declines in the pre-crisis boom period.

\footnotetext{
${ }^{1}$ Recent papers on lending distance use either cross-sectional surveys (e.g., Brevoort and Wolken, 2008, Petersen and Rajan, 2002) or proprietary datasets obtained from a single financial institution (e.g., Agarwal and Ben-David, 2014 Agarwal and Hauswald 2010).
} 
Before turning to explanations, we establish one more set of facts. We proxy for the degree of local lending competition with the Herfindahl index for bank loans made in the county at the beginning of our sample period. We find banks whose branches are primarily in competitive banking markets see a more pronounced cyclical pattern in average lending distance. If competition is the driver of distance lending, then banks in such counties are likely to look for borrowers in less competitive areas. Indeed, we find a similar cyclical pattern in average borrowing distance for borrowers located in less competitive areas. Finally, tying these two patterns together, we show that distant loans made from a competitive area to a less competitive area are also procyclical.

What might explain these patterns? We draw on the seminal work of Drechsler, Savov, and Schnabl (2017, henceforth DSS (2017)) to explain why distant lending took off when it did in 2004-2007.DSS (2017) argue that, when the Federal Reserve starts raising interest rates (typically in response to an economy starting to overheat), banks in concentrated (less competitive) banking areas do not pass on the entire rate increase to their depositors as they try to squeeze rents out of passive, sticky depositors. Deposit growth slows in such areas, which also slows lending growth resulting in what DSS (2017) term the deposits channel of monetary policy. Of course, the more flighty depositors in such banks as well as first-time depositors would look for better rates elsewhere in the traditional banking system or outside of it. We conjecture that within the banking system, they would find higher rates in competitive banking areas. So a rise in policy interest rates should result in deposits flowing to competitive banking areas, and away from concentrated areas. Since banks in competitive areas retain their existing deposits as well as attract new ones, they are likely to have an abundance of loanable funds relative to lending opportunities - a positive funding shock.

What would banks do with the deposits surge? They could store it, for instance, by investing it in Treasury bills. It may be difficult, however, for bank management to hold loanable funds passively if competitors seem to have no difficulty booking fees by making loans. This is especially so if shareholders and analysts can easily track banks' loan volumes. Thus, instead of making more sub-par local loans to borrowers in competitive areas that are typically well funded, short-horizon bank managers might keep up appearances by making more distant loans (see Agarwal and BenDavid, 2014, Rajan, 1994; Stein, 1989). Indeed, the contraction in lending by banks situated in more concentrated areas as their deposits shrink, would create precisely such a distant lending opportunity.

Yet, this "opportunity" may be a poisoned chalice. Once banks go beyond the limits afforded by technology, they do not have the same ability to undertake the ex-ante due diligence and expost monitoring of borrowers that more proximate banks would have. Moreover, some of the loan demand in concentrated areas that distant banks pick up comes from borrowers that proximate banks stopped lending to. Thus, banks face an adversely selected sample amongst their distant borrowers. This argument can explain why distant loans made at such times underperform, as we show.

In sum, the monetary-policy-tightening-induced rearrangement of liquidity between concentrated and competitive areas creates a shift of deposits to the latter areas, which in turn "burn 
a hole" in the pockets of short-horizon banks located there, and cause them to expand distant lending. This combination could explain the unprofitable distant lending we have documented. We find evidence consistent with this explanation (and each of its elements).

First, as DSS (2017) suggest and we show, deposit growth in 2004-2007 is higher in the more competitive banking areas than in the more concentrated banking areas (as measured by deposit concentration). Next, we compute interest expense betas following DSS (2017). These interest expense betas measure the sensitivity of interest rates paid by banks to changes in the Fed Funds rate. A low interest expense beta implies that a bank exercises its market power to keep its deposit rates low when nation-wide interest rates go up. We find that when the loan-origin county has a greater interest expense beta (i.e., the market for deposits is more competitive), the average distance of loans made from that county tends to be more procyclical. Conversely, when a destination county has a lower interest expense beta, the average distance of loans made into that county also tends to be procyclical. So loans are made from counties that are likely to not just retain their deposits but also experience inflows, to counties that are likely to see deposits shrink.

Second, we have argued that managerial short-termism can explain why some bank CEOs see deposit inflows as "burning a hole in their pocket" and want to redeploy it in distant loans, even if they are not very good at making them. We use four different proxies for managerial short termism: (i) whether the bank is publicly listed (e.g., Falato and Scharfstein, 2016), (ii) whether it puts low weight on risk management (Ellul and Yerramilli, 2013), (iii) whether it does not have a Big-4 auditor (DeFond and Zhang, 2014), and (iv) whether the fraction of managerial pay based on bonuses and options in 2006 is high (Fahlenbrach and Stulz, 2011). We find that all four measures (individually and collectively) are associated with significantly greater procyclicality in lending distances. In addition, we examine banks whose branch networks span concentrated and competitive areas. As the Fed raises rates, such banks can simply transfer excess funds obtained from branches in competitive areas to funds-deficient branches in concentrated areas, where there are likely to be proximate lending opportunities. Such banks are unlikely to engage in procyclical distance lending. We find this is indeed the case, which further indicates that the agency problem resides at the level of top management.

Our evidence thus far leads to a broader question, though. Could the liquidity-flush banks be recycling deposits into lending in other risky ways? That is, risk taking in small business lending could indeed be part of a broader pattern of risk taking by specific banks. We explore this possibility. Specifically, we know the overall loan losses for each bank and hence can determine the average non-performing loan ratio for each bank over the 2007-2009 period. We find that the higher the average non-performing loan ratio of a bank, the more procyclical is its distance lending, suggesting that heightened small business loan distances are associated with more general bank risk taking in lending. Some of these risks might be idiosyncratic, of course. So next, we use a returnsbased measure of risk to gauge whether greater procyclicality in lending distances are indicative of banks' systematic risk exposures. Following Acharya, Pedersen, Philippon, and Richardson (2017) and Meiselman, Nagel, and Purnanandam (2020), we capture a bank's exposure to aggregate tail 
shocks through its average return during the $5 \%$ worst days for the market. We find that, in the cross-section of banks, this return-based measure of systematic risk is strongly correlated with the procyclicality of a bank's distance lending (as measured by the correlation coefficient between a bank's average lending distance and each of our business cycle indicators).

How generalizable are our findings? Do sudden deposit inflows into a segment of banks always generate poor lending outcomes? Our findings are certainly reminiscent of the recycling of petrodollar deposits after the oil price hikes in the 1970s (e.g., Ocampo, 2014). Oil producers, flush with dollar inflows, deposited their funds with multinational banks that then lent them to fundsdeficient Latin American economies. Their over-borrowing culminated in the Latin American debt crisis in the 1980s. There too, a surge in deposit inflows "burnt a hole" in bank pockets and were recycled to eager borrowers by short-horizon bank management. Yet, there are also circumstances when central banks pump liquidity into banks in a vain effort to get them to lend. Our paper suggests possible differences in scenarios when liquidity "burns a hole" in bank pockets and causes them to expand lending and when liquidity flows are analogous to pushing on a string. We do not, of course, rule out the possibility that neglected risks, over-optimism or irrational exuberance contribute to lending frenzies as well (e.g., Gennaioli, Shleifer, and Vishny, 2015, Pflueger, Siriwardane, and Sunderam, 2020). Our focus on liquidity and agency problems, however, suggests important contributing factors to frenzies that can be addressed by policymakers.

We are obviously not the first to examine distance lending. A number of papers have also shown the cyclicality of cross-border lending (see, e.g., Cerutti, Hale, and Minoiu, 2015; Giannetti and Laeven, 2012; De Haas and Van Horen, 2013; Kleimeier, Sander, and Heuchemer, 2013). In domestic markets, Degryse, Matthews, and Zhao (2018) and Presbitero, Udell, and Zazzaro (2014) show that banks cut back on distant loans during the crisis. Our contribution is to connect the increasing lending distance pre-crisis with bank risk taking more closely, and to provide an explanation based on monetary-policy-induced funding flows, competition, and agency.

Our explanation is most closely related to Drechsler, Savov, and Schnabl (2019). They show that, as the Fed raised interest rates starting in 2004, non-banks and private label securitizers rushed into areas where banking was concentrated, and because they were less adept at lending, made low quality loans. Our focus, in contrast, is solely on banks. The flow of deposits between banks (from concentrated to competitive areas) created liquidity inflows that worsened loan quality even in bank loans to small businesses. More broadly, our paper highlights that deposit growth, in combination with inter-bank competition and managerial short-termism, literally burned a hole in bank pockets.

The rest of the paper is as follows. We start by describing the data, provide evidence for the procyclical nature of distance lending, show how such lending leads to larger loan losses without a commensurate rise in ex-ante interest rates charged, and finally show that distance lending typically goes from counties where banking is competitive to counties where banking is not. We then turn to possible explanations, providing evidence that deposit surges "burned a hole in the pocket" of shorthorizon banks We discuss the aspects of our findings that are generalizable, and offer suggestive 
evidence that distance lending is a proxy more generally for systemic risk taking. We conclude by setting the findings in the literature and discussing possible further research.

\section{Data Description}

We obtain lending data from the Community and Reinvestment Act (CRA) small business loans database provided by the Federal Financial Institutions Examination Council (FFIEC). This dataset contains information on the total number and volume of small business loans originated by each reporting financial institution in each county of the United States during a calendar year. Between 1996 and 2004, all commercial and savings banks with total assets exceeding $\$ 250$ million were required to report. Since 2005, the FFIEC raised the mandatory reporting asset size threshold from $\$ 250$ million to $\$ 1$ billion. Following this increase in the asset-size threshold, the number of banks reporting to the CRA small business lending dataset declined from approximately 2,000 to 1,000. For our analysis, we use the entire sample of banks available at any time. The empirical results are similar when we use a constant sample of banks with more than $\$ 1$ billion in assets.

We use the FDIC's Summary of Deposits (SOD) database to obtain information about the geographic characteristics of all branches of depository institutions operating in the United States between 1996 and 2016. This dataset contains information on the geographical coordinates, location, and deposits of each branch in the United States. We complement the SOD dataset by assigning latitudes and longitudes to each branch address whenever geographic coordinate data are missing. We use information on the address, zip code, and county of the branch to retrieve the missing branch latitudes and longitudes via the Google Geocoding Application Programming Interface (API). We also obtain financial characteristics of the commercial and savings banks from the quarterly Reports of Condition and Income (Call Reports) that banks file with the FDIC. Financial information on savings banks prior to 2012 comes from Thrift Financial Reports available from the SNL Financial dataset.

We know from the CRA dataset the quantity of small business loans $l_{b c t}$ that a specific bank $b$ has made to a specific county $c$ in year $t$. We combine the SOD dataset on bank branch locations with information on the latitudes and longitudes of the geographic centroids of all U.S. counties. For the CRA dataset $2^{2}$ we assume that the closest geodetic distance $d_{b c}$, i.e., the length of the shortest curve between the centroid of borrower county $c$ and the closest branch of bank $b$, represents the average distance between the bank's borrowers in county $c$ and the bank (branch) itself. We believe that this is a sensible measure of distance based on existing survey evidence suggesting that $59 \%$ of all US small banks receive small business loan applications at any branch, while $30 \%$ accept small business loan application at branches with loan offices, and only $11 \%$ accept applications online (FDIC, 2017). Thus, the value-weighted average loan distance for bank $b$ in year $t$ is $\frac{\sum_{c=1, N} l_{b c t} d_{b c}}{\sum_{c=1, N} l_{b c t}}$, where $N$ is the total number of counties it has made loans to. For the entire economy, distance is $\frac{\sum_{b} \sum_{c=1, N} l_{b c t} d_{b c}}{\sum_{b} \sum_{c=1, N} l_{b c t}}$.

\footnotetext{
${ }^{2}$ As described below, we use a slightly different approach for the SBA dataset because of differences in data.
} 
We compute other measures of geographic distance such as the distance between the populationweighted centroid of each county (rather than the geographical centroid) and the closest branch of the bank, the distance between each borrower county centroid and the headquarters of each bank, and an indicator variable that takes the value of one if a bank has no branch in the county where it originated small business loans, essentially coding out-of- versus in-county lending. We show in the Online Appendix that the main results are not sensitive to these alternative measures of distance between lenders and borrowers.

Since the CRA dataset does not contain loan-by-loan default or interest data, we also use the Small Business Administration (SBA) dataset, which contains a list of all SBA-guaranteed loans under the 7(a) program from 2000 to $20163^{3}$ It contains loan-level information about the identity, address, city, and zip code of the borrowers and lenders as well as loan characteristics such as the total amount, the amount of the SBA's loan guarantee, the initial interest rate, the approval date, the industry of the borrower, and the loan status (performing/default). The dataset also includes information on the charge-off date and on the amount charged-off by the SBA on its loan guarantee when the loan is charged-off by the bank. Following Brown and Earle (2017), we exclude cancelled loans from the analysis because the cancellation may be at the initiative of the borrower.

For the SBA dataset, using the University of Chicago Geographic Information Service (GIS), we geocode the geographic coordinates of approximately 1 million borrowers and their lenders 4 We are unable to locate the geographic coordinates of approximately $0.6 \%$ of the SBA borrowers in the dataset and we discard those observations. We compute the distance between borrowers and lenders in the dataset as the geodetic distance between the reported addresses of borrowers and respective lenders in the SBA dataset. This might seem more precise than our earlier method for the CRA dataset, but there is an important caveat: the lender address is usually the bank's headquarters and not necessarily the closest branch. We could follow our earlier strategy and determine the closest bank branch. Unfortunately, the loan-level SBA dataset does not include the regulatory identifiers of the lenders that originated the SBA loans, and there is the potential for error in using the reported bank name (since they can be partial or truncated) 5 Therefore, the SBA dataset is more precise about borrower location, while the CRA dataset arguably is more precise about lender location. Nevertheless, the cyclical properties of the distance proxies in both datasets are similar, allaying concerns about comparability or measurement error.

\footnotetext{
${ }^{3}$ The 7 (a) program is SBA's primary and most popular general-purpose, government-guaranteed lending program.

${ }^{4}$ We are grateful to Todd Schuble at the Research Computing Center of the University of Chicago for assistance in geocoding the geographic coordinates of the SBA borrowers' addresses.

${ }^{5}$ For a limited set of lenders, we hand-matched the information in the SBA to the SOD and computed the geographic distance between the address of the borrower and that of the closest branch of the respective lender. In the Online Appendix, we use this alternative measure and we show that the cyclicality in the evolution of lending distances in the SBA data is not sensitive to this alternative definition.
} 


\section{Lending Distances, Bank Lending, and Business Cycles}

In this section, we document the main empirical patterns in banks' lending distances over the business cycle using the CRA dataset. We use regressions to more formally evaluate the role of the business cycle in shaping the relation between lending distances and changes in bank lending.

\section{A. Summary Statistics}

We begin our analysis by presenting basic information about the market for small business loans over the 1996 to 2016 sample period. Panel A of Table 1 shows that small business lending increased substantially over this period: the total volume of small business loans originated by CRA-reporting banks approximately doubled in current dollar terms from $\$ 115$ billion in 1996 to $\$ 227$ billion in 2016. The growth in the aggregate amount of small business loans was, however, not always steady over this period. During the 2001-2007 period, small business lending increased substantially to a peak of $\$ 324$ billion in 2007 and subsequently saw a sharp decline to half of that amount during the Great Recession.

Small business lending is still mostly a local activity. Figure 1 and Panel A of Table 1 show that approximately $80 \%$ of all small business loans originated in the U.S. over the sample period went to borrowers that are less than 50 miles away from the closest branch of their bank lender, whereas only $7.5 \%$ of all small business loans went to borrowers that are located more than 1,000 miles away from the closest branch of their lender. The share of small business loans made to distant borrowers has nevertheless fluctuated substantially over time. Figure 1 shows that, between 2001 and 2007, distant lending increased at a faster pace than nearby lending and that the share of distant loans in the small business lending market increased substantially. The ensuing contraction in the 2007-2010 period was, however, more pronounced for distant loans and the share of the small business lending market accounted for by distant loans returned to pre-2003 levels in the years that followed the Great Recession.

Panel A of Table 2 reports summary statistics of the main variables used in the empirical analysis. The unit of observation is the (borrower) county-bank-year combination. The sample includes a bank-county combination from the start of the sample until the moment in which the bank disappears from the sample, if the bank originated at least one small business loan to that county over the entire sample period. The sample includes approximately 5 million observations but only 2 million observations see non-zero growth in lending across two consecutive years. The large number of zeros occurs because it is not uncommon for a bank to lend nothing to borrowers in a specific county for two consecutive years ${ }^{6}$ The average growth in bank lending to a county is $13.5 \%$. Consistent with the intuition that banks from more competitive areas seek lending opportunities in less competitive areas, we also see the destination (borrower) markets are, on average, more concentrated (as measured by the Herfindahl-Hirschman Index (HHI) of lending in each county at

\footnotetext{
${ }^{6}$ To check that the results are not sensitive to this characteristic of our dependent variable, we use alternative dependent variables (Table IA.1) and limit the sample to (borrower) county-bank combinations for which we see more than 100 loans originated over time (Table IA.6).
} 
the beginning of our sample) than the origin (lender) markets where the bank's closest branch is located.

In Figure 2, we present key statistics about the evolution of lending distances over time. In Panel A, we plot the average distance of all small business loans weighted by their respective dollar amount from 1996 onward. The figure shows that average distances between borrower and lender trended positively over the sample period. From 1996 to 2016, average distance increased from approximately 100 miles to 250 miles. But the evolution of average lending distance did not always follow trend. Between 1996 and 2003, average distances rose steadily except for a decline in 2001. From 2004 until 2007, average-lending distances increased sharply above trend from approximately 175 miles to 350 miles and the Great Recession saw a significant pullback in average distances to pre-2004 levels. This boom and bust in distance is the focus of our analysis.

The cyclical pattern holds when we compute alternative measures of lending distance between lenders and borrowers. Figure 2, Panel B shows the evolution of an equal-weighted average distance, which is determined as the simple average of lending distance computed bank by bank. On average, banks expanded their lending distances over the sample period and such expansion was strongly procyclical. In particular, average bank lending distances increased sharply between 2003 and 2007 and subsequently contracted in the ensuing years. This finding already suggests that the previous results are not simply driven by an increase in the sample representation of larger banks that specialize in distant lending. In Panel $\mathrm{C}$ of Figure 2, we compute the proportion of all small business loans made to borrowers located outside counties where the lending bank has a local branch. Similar to the previous results, this fraction exhibits a trend increase between 1996 and 2016 with an abrupt deviation from trend between 2004 and 2010.7

We also examine the evolution of distance across several points of its distribution. Figure 3 presents the median lending distance (Panel A), the lower decile of lending distance (Panel B), and the upper decile of lending distance (Panel C) over the sample period. Consistent with the notion that small business lending is very local, the median distance in the sample varies from approximately 4 miles in 1996 to a peak of 8 miles in 2007. The evolution of lending distance is, nevertheless, similar across the different points of the distribution: lending distances exhibit an upward trend over the sample period and strong procyclicality, with rapid above-trend growth in lending distances between 2004 and 2007 and a subsequent sharp decline until 2010. These patterns suggest that a shift in the entire distribution of lending distances, rather than a few outliers, drive the observed changes in average lending distance over time.

\section{B. Regression Results}

In this section, we formally examine how economic conditions mediate the relation between lending distance and changes in bank lending. We estimate an ordinary-least-squares (OLS) model of the change in the volume of small business loans originated by each bank in each county as a

\footnotetext{
${ }^{7}$ In the online appendix, we show that the shape of these figures is not sensitive to the effects of mergers and acquisitions or to using a population weighted county-centroid to compute distance between borrower and lender.
} 
function of the distance of the bank to the county and the interaction between this distance and a measure of the state of the cycle (business/financial). Specifically, we estimate the following specification:

$$
\Delta \ln (S B L)_{b c t}=\alpha_{c t}+\gamma_{b}+\beta_{1} \ln (D i s t)_{b c t}+\beta_{2} \ln (D i s t)_{b c t} \times Z_{t}+\theta X_{b t}+\epsilon_{b c t}
$$

where $b$ indexes a bank lending to borrowers located in county $c$ during year $t$. The dependent variable, $\Delta \ln (S B L)_{b c t}$, is the change in the natural logarithm of one plus the volume of small business loans originated by bank $b$ in county $c$ during year $t$. Our main variable of interest, $\ln (D i s t)_{b c t} \times Z_{t}$, is the interaction between lending distance and a cycle indicator, $Z_{t}$, defined alternatively as (i) the detrended change in real gross domestic product (GDP), (ii) the log difference in the US annual unemployment rate, or (iii) the standardized net percentage of banks increasing spreads (of loan rates over their cost of funds) to small firms 8 We control for time-varying banklevel characteristics such as size and the shares of residential loans and commercial real estate loans in $X_{b t}$. The main coefficient of interest, $\beta_{2}$, captures whether the relation between lending distance and changes in bank lending is more or less pronounced depending on the state of the cycle. It is essentially a semi-elasticity of lending growth with respect to geographic distance and the state of the economy.

We include (borrower) county-by-year fixed effects $\alpha_{c t}$ and bank fixed effects $\gamma_{b}$. It is important to understand what they do. For instance, some counties may be neglected by banks (i.e., have few local banks) and hence may receive a larger share of their small business credit from distant lenders. We need to control for the possibility that loan demand in these counties grows relatively more in expansions (and relatively less in recessions). Therefore, we include (borrower) countyby-year fixed effects that absorb any time-varying unobserved county characteristics as well as local demand shocks. The bank fixed effects ensure that the relevant coefficients are estimated off variation in lending distance within a bank and not off variation in the composition of lenders in the economy. Otherwise, it could be that banks specializing in distant lending become a larger share of the sample during expansions and subsequently lose share during recessions. In sum then, the coefficient of interest, $\beta_{2}$, is positive if in business cycle upswings, loan growth within a county comes disproportionately from faraway banks (and these banks typically lend closer to their branches in more normal times). We cluster standard errors at the county-level.

Table 3 presents results that are largely consistent with the descriptive statistics of Figures 2 and 3. The coefficient on distance, $\beta_{1}$, is negative and significant across all three specifications, suggesting that when the economy is in a neutral state and credit conditions are normal, greater distance to borrowers is associated with lower lending growth. More importantly, as the interaction term indicates, when the economy is booming, the negative relation between lending distances and changes in bank lending is significantly attenuated and can even become positive. Put dif-

\footnotetext{
${ }^{8}$ The net percentage of banks increasing spreads of loan rates over their cost of funds was negative and decreasing between 2004 and 2007 as the Fed raised interest rates, then rose and turned positive through the financial crisis, turning negative again around 2010 (see https://fred.stlouisfed.org/series/DRISCFS)
} 
ferently, banks make relatively greater volumes of distant loans in good times. Putting the direct and interaction effects together, column (1) suggests that when the detrended real GDP series is one standard deviation above the mean, changes in bank lending are not significantly related to differences in physical distance between borrower and lender. Similarly, the results of Columns (2) and (3) suggest that a one-standard deviation decrease in the unemployment rate or the fraction of banks increasing loan spreads approximately halves the estimated negative relation between lending distance and bank loan growth.

Consider an alternative approach in which we allow the relationship between lending distance and loan growth to vary non-parametrically over time. Specifically, we estimate:

$$
\Delta \ln (S B L)_{b c t}=\alpha_{c t}+\gamma_{b}+\sum_{t} \beta_{t} \ln (D i s t)_{b c t} \times Y e a r_{t}+\theta X_{b t}+\epsilon_{b c t}
$$

where $Y_{\text {ear }}$ is a set of dummy variables that equal to one at time $t$ and zero otherwise and all other variables are defined as above.

In Figure 4, we plot the series of estimated coefficients, $\left\{\beta_{t}\right\}$, and corresponding standard errors overlaid on the dashed line representing the detrended GDP growth series. The figure further suggests that recession years coincide with lower estimated coefficients between lending distances and changes in bank lending and boom periods coincide with higher coefficients and even positive associations between lending distances and changes in bank lending. The univariate correlation between the series of year-specific effects of lending distance with the detrended real GDP series is 0.56. We interpret the results of this plot as supplementary evidence that the relation between lending distances and loan growth at those distances is strongly procyclical.

Next, we perform a battery of robustness checks to confirm this procyclical relation between lending distances and changes in bank lending. First, we examine whether this cyclical pattern is common across banks of different sizes, rather than limited to a few very large banks. In Table 4, we stratify the sample based on whether banks have less than $\$ 10$ billion in total assets, between $\$ 10$ and $\$ 50$ billion in total assets, and more than $\$ 50$ billion in total assets at the end of 2005 . The results indicate that the cyclical relation between lending distances and changes in bank lending is common to all bank sizes. Furthermore, in the Online Appendix, we report that our results are not sensitive to using alternative dependent variables (Figure IA.1 and Table IA.1), other measures of distance (Figure IA.3, Tables IA.2 and IA.3), other business cycle indicators defined at the state or local-level (Table IA.4), winsorization of the main dependent variables (Table IA.5), limiting our sample to bank-county combinations whose number of total loan originations over the sample period exceed a minimum threshold (Table IA.6), and to re-estimating the main specification of the paper excluding one state at a time (Figure IA.4).

Another potential concern is that the composition of borrowers or loans changes over the business cycle - for example, during economic expansions loans may flow to industries that allow for more distance in lending because of collateral type and quality. To examine whether the cyclical variation in distance is likely driven by changes in the pool of borrowers over the cycle, rather than 
by changes in the willingness of lenders to make distant loans, we exploit a separate CRA dataset that covers only small agricultural loans. Agriculture is a monitoring-intensive industry, in which lenders must at least deploy some resources to check if the farmer is putting the loan to good use. Figure 5 shows that small farm loan data also exhibit cyclicality in lending distance. While the average lending distance in the agricultural sector is less than for the rest of the economy, consistent with farm loans being more monitoring intensive, the plot shows within-sector, above-trend growth in lending distances during economic expansions and subsequent declines in lending distance following recessions. In the Online Appendix (Table IA.7), we further show that the cyclical relation between lending distances and changes in farm loans holds in an empirical specification similar to that of equation (1). These results suggest that cyclicality is not simply driven by time-varying industry or loan composition. Furthermore, to the extent that farm loans are less subject to demand side cyclical changes associated with the business cycle, this does suggest the observed cyclicality has something to do with the supply side of bank loans - the banks themselves.

Overall, the results in this section strongly support the idea that lenders are more willing to extend credit to distant borrowers during economic expansions and subsequently pull back in the ensuing downturn.

\section{Lending Distances and Loan Losses}

Small business lending is best done at close quarters - the median loan in 2002 in the CRA sample was at a distance of about 5 miles (see Figure 3, Panel A). Are distant loans originated during booms therefore of lower quality, and more likely to default?

\section{A. Lending Distances and Loan-Level Loan Losses: Evidence from the SBA Loans}

As indicated earlier, the CRA dataset does not contain data on the performance of small business loans. Therefore, we use the Small Business Administration (SBA) dataset of government guaranteed loans, which does have loan-level information on ex-post defaults (also termed chargeoffs), and also data on the identities and addresses of borrowers and lenders, loan amounts, interest rates, and maturities of all government guaranteed loans approved since 2000 9

We first establish that the basic patterns of distance lending apply also in the governmentguaranteed SBA lending market, which then allows us to exploit the SBA loan performance data. Toward this end, we provide analogous figures and regressions for the SBA 7(a) dataset. Figures IA.5, IA.6, IA.7, and Table IA.8 in the Online Appendix show that the evolution of distance in the SBA dataset exhibits cyclical patterns that are similar to those in the broader small business loan market. Based on this evidence, we proceed to examine how the relation between ex-post loan defaults (charge-offs) and lending distances moves over time using loan-level SBA data.

\footnotetext{
${ }^{9}$ In this dataset we use distance between the bank HQ and the borrower addresses. Unlike the measure of distance used in the previous analyses, this measure of distance can vary over time within a county-bank pair because different borrowers may be at different places within the same county over time.
} 
Average default rates on SBA loans are not low. Figure 6 shows that the fraction of loans that were charged off (because they defaulted at least in part) hovered just above 10 percent across distance bins for loans originated in 2001; they were around 5 percent across distance bins for loans originated in 2011. However, for loans originated in 2005, they were just over 20 percent for the 0-100 mile bin, climbing to over $30 \%$ for loans made at a distance of greater than 500 miles. The peak charge-offs seems to be for loans originated in 2007, when charge-offs were around 30 percent for the closest bin and over 40 percent for the most distant bin. So the probability of default rose substantially for loans that were originated during the years that just preceded the crisis 10 More relevant for us, the probability of default increased with distance for loans from the years that preceded the crisis. We analyze more formally whether distance is associated with higher default rates, especially for vintages originated during the boom 11

We estimate the following specification:

$$
P R\left(C O_{i b c t}=1\right)=\alpha_{c t}+\gamma_{b}+\sum_{t} \delta_{t} \ln (\text { Dist })_{i b t} \times Y_{e a r_{t}}+\theta X_{i}+\epsilon_{i b c t}
$$

where $i$ indexes government-guaranteed SBA loans originated by lender $b$ to small business borrowers located in county $c$ during year $t$. The main variables of interest, $\ln (\text { Dist })_{i b t} \times Y e a r_{t}$, are interaction terms of the log-distance between the addresses of the lender and the borrower and a series of year dummies. We further include county-by-year and bank fixed effects as well as additional controls for loan-level characteristics in the vector $X_{i}$, such as the loan interest rate, loan maturity, and a full set of borrower-industry fixed effects. As before, standard errors are clustered at the county-level.

The inclusion of county-by-year and bank fixed effects ensures that the results are not driven by changes in local economic conditions or unobservable bank characteristics that affect the likelihood of default of small business loans originated in a county. We are, therefore, comparing the average outcomes of loans to borrowers in a country originated by nearby lenders relative to the average outcomes of loans to borrowers located in the same county that receive loans from distant lenders.

We present the results of this analysis in Figure 7. The evolution of the coefficient of interest exhibits a very clear pattern: over the initial years of the sample period, lending distances are not significantly related to the likelihood of charge-off. However, beginning in 2003, the relation between distance and the likelihood of charge-off becomes positive and statistically significant. The magnitude of the estimated coefficient increases over time and peaks for loan vintages originated in 2006. At the peak, the results suggest that a one-percent increase in our distance measure is associated with a $2 \%$ increase in the charge-off probability. This magnitude is economically significant, even when we benchmark it against the unconditional charge-off probability of approximately $15 \%$

\footnotetext{
${ }^{10}$ There is, however, a mechanical aspect to this relation in that many loans that were originated well before the crisis would have been fully paid off before the crisis years. The crisis constituted an ex-post change in real conditions that would have stressed any loan, no matter how careful the ex-ante diligence was.

${ }^{11}$ We confirm that our results are not sensitive to using a sample of SBA loans whose maturity is less than or equal to five years and that were originated prior to 2013 (in order to allow for enough time for all loans to be worked-out by the end of the sample period).
} 
reported in Panel B of Table 2. After 2006, the relation between lending distances and likelihood of charge-off becomes less pronounced and turns statistically insignificant after 2010.

An important caveat about this analysis is that the government guarantee for SBA loans could have exacerbated incentives to throw caution to the wind relative to other small business loans without a guarantee. Lenders in a SBA-guaranteed loan only absorb a predetermined fraction of potential loan losses (typically 15-25 percent of all losses) but earn full interest and fees accruing from the loan. This feature raises concerns about whether the results generalize to the broader lending market. To assess this concern, we partition the sample based on whether a loan was originated under the regular 7(a) program or under the SBA Express program. The SBA Express program ensures an expedited review of documentation by the SBA (usually less than 24 hours) in exchange for a lower government guarantee, $50 \%$ rather than the usual $75 \%$ or $85 \%$ guarantee of a regular 7(a) loan. In the Online Appendix (Figure IA.8), we repeat the analysis of Figure 7 for the subsets of regular 7(a) and SBA Express loans. We find that the relationship between distance and charge-offs, if anything, is somewhat stronger in the immediate pre-crisis years for the SBA Express loans that feature a lower government guarantee, though typically the estimates are not statistically different.

\section{B. Cyclical Lending Distance and Loan Characteristics}

Before concluding this sub-section on defaults, we ask whether distant loans are in some way different from proximate loans ex ante - for instance, do they have greater priority in repayment because of seniority or collateral (so that the loss given default is lower) or does the bank charge higher interest rates on them. The latter sheds light on the question whether banks demand compensation and charge more for riskier distance loans.

We do not have data on the effective priority of the SBA loans. But we know the loss given default on these loans. We plot the average loss given default of charged-off loans in different distance bins for different years of origination in Figure IA.9 in the Online Appendix. In general, the average loss given default rises before the crisis (around $66 \%$ in 2003, $73 \%$ in 2005, and $81 \%$ in 2007) but is generally flat across distance segments - in 2007, a year with a steep increase in default rates across distance bins, the loans in the 0-100 miles segment have an average loss given default of $82 \%$, while the loans in the over 500 mile bin have a loss given default of $78 \%$. Thus, it does not appear that distant loans have significantly higher priority or better collateral terms that offsets the higher default rate.

Next, we investigate whether lenders require additional compensation for distant loans originated in the run-up to the financial crisis. One drawback is that interest rates on SBA loans are highly regulated. The SBA sets a maximum rate of the Prime rate $+2.25 \%$ for loans with principal amount of more than $\$ 50,000$ and maturity of less than 7 years, and Prime $+2.75 \%$ for loans with

principal amount of more than $\$ 50,000$ and maturity of 7 years or more. In spite of these rate ceilings, there is some variation in the interest rate on loans, even for those approved by the SBA on the same day. This suggests that not all loans are set at the maximum allowed interest rate. 
We assess if lenders require additional compensation for distant loans originated in the run-up to the financial crisis, using an empirical specification similar to that of equation (3), in which we use the initial interest rate on the SBA loan rather than the charge-off probability as the main dependent variable. We report the results in Figure 8. We do not observe any clear cyclical pattern in the sensitivity of interest rates to distance - if anything, the sensitivity of interest rates to distance declines in the lead up to the crisis, relative to earlier years. It increases only after the crisis (after 2010). Clearly, lenders do not obtain additional compensation for the higher losses they later incur with distant loans.

Overall, the results in this section are consistent with the idea that during expansionary periods, banks lower credit standards and extend credit to distant small business borrowers, who are relatively harder to evaluate and monitor. If we multiply the fraction of charge-offs in the most distant bin (over 500 miles) in 2007 by the loss given default, we obtain the realized loss. Compared to the realized loss in the most proximate bin (less than 100 miles), the additional realized loss is 8 percent of loan value for loans originated in 2007 for the most distant loan bin. It is possible that banks would have wanted to charge higher interest rates, if they had anticipated these outcomes. But our evidence suggests they did not. Perhaps they did not realize they were taking significantly more risk when they were extending distance, given their lack of knowledge of local circumstances. Perhaps there were economic incentives to make such loans, despite the risks. This leads to the central question: Which banks engaged in distance lending and the associated risk-taking and why?

\section{Lending Distances and the Role of Competition}

Having established that distant loans made during the cyclical expansion are riskier and less profitable than proximate loans, we turn to the conditions under which such bank behavior emerges. Banks whose branches are primarily in competitive banking markets could have relatively scarce lending opportunities and hence may seek distant borrowers in less competitive areas rather than sitting on un-lent cash. We first explore the role of competition and then come back to why bank managers in competitive areas might want to lend 12

\section{A. The Role of Competition in Home and Destination Markets}

To test whether local competitive pressures amplify the cyclical relation between lending distances and changes in bank lending, we use variation in the intensity of competition at the countylevel in the small business lending market. Our measure of competition is the Herfindahl-Hirschman Index (HHI) for the small business loan market in each county at the beginning of our sample 13

We first group banks based on the average HHI of their home markets, i.e., the HHI of origin

\footnotetext{
${ }^{12}$ See, for example, Degryse and Ongena (2005) on the role of proximate bank competition on interest rates banks can charge, and also Zentefis (2020).

${ }^{13}$ We also compute a measure of competition based on the HHI in the deposit market. The results for this alternative measure of market concentration, reported in the Online Appendix, are qualitatively and quantitatively similar. See Drechsler et al. (2017) for the use of deposit HHI as a proxy for bank competition.
} 
counties, where the borrowers' closest branch is located. We plot the time-series of banks' average lending distances separately for home markets that are below and above the median HHI. The lending distances of banks with below-median concentration in their home markets (the red line in Figure 9, Panel A) are more cyclical than those of banks with above-median concentration in their home market (the green line). For example, banks facing stiffer competition at their local branches, i.e., those with below-median HHI in their home markets, expanded bank-level average lending distances from 80 miles in 2003 to approximately 130 miles in 2006, and subsequently saw their lending distances contract to less than 100 miles by 2010. Banks with branches in counties with above-median HHI, i.e., those facing lower competition in their home (or local) markets, saw no such cyclical pattern and their bank-level average lending distances hovered around 40 miles throughout the entire sample period. Thus, the figure suggests that banks exposed to greater competition not only lend at a greater distance, but importantly, also see a more pronounced boom-bust cycle in lending distances.

One potential problem with the competition analysis is that banks operating branches in aboveand below-median HHI markets could be systematically different in ways that affect the relation between lending distance and changes in bank lending but do not necessarily reflect local competitive pressures. To formally examine whether exposure to greater competition amplifies the cyclical relation between distance and changes in bank lending, we expand the specification of equation (1) by including a triple interaction between the level of market concentration, lending distance, and the business cycle indicators. Specifically, we estimate the following model:

$$
\Delta \ln (S B L)_{b c t}=\alpha_{c t}+\gamma_{b}+\beta_{1} \ln (D i s t)_{b c t}+\beta_{2} \ln (D i s t)_{b c t} \times Z_{t} \times H H I_{b c}+I N T+\theta X_{b t}+\epsilon_{b c t}
$$

where $H H I_{b c}$ measures the county-level HHI of the small business lending market at the beginning of the sample period. We compute $H H I_{b c}$ in the home market, destination market, and as the difference in HHI between the destination and home market. We include all two-way interaction terms (INT) between the HHI terms, lending distance, and business cycle. We cluster standard errors at the county-level.

Table 5 reports the results. We find that local bank competition is associated with greater cyclicality in the relation between lending distance and changes in bank lending. The interaction term between lending distances and business cycle indicators suggest that distance is more positively associated with changes in bank lending in expansionary periods. But more importantly, the estimated coefficient of the triple interaction between the HHI measures, lending distances, and business cycle indicators supports the notion that competitive pressures amplify the business cycle effects. For example, the results of Column (3) of Table 5 suggest that a one-standard deviation increase in the difference between the HHI of the destination and home markets raises the marginal effect of the interaction between lending distance and the detrended GDP by approximately $25 \%$ $(=0.008 / 0.035)$. Thus, when the difference in HHI between destination and home markets is large, lending distances and changes in bank lending are even more positively associated in expansionary 
periods and more negatively associated in recessionary periods. We obtain similar results with slight differences in economic magnitudes in the other columns of Table 5.

We also investigate the role of market concentration using a non-parametric approach similar to that of specification (2). Specifically, we estimate the following model:

$$
\begin{aligned}
\Delta \ln (S B L)_{b c t} & =\alpha_{c t}+\gamma_{b}+\sum_{t} \delta_{t} \ln (\text { Dist })_{b c t} \times Y e a r_{t} \\
& +\sum_{t} \lambda_{t} \ln (\text { Dist })_{b c t} \times Y_{e a r_{t}} \times H H I_{b c}+I N T+\theta X_{b t}+\epsilon_{b c t}
\end{aligned}
$$

where our independent variable of interest is the triple interaction between the lending distance, year dummies, and the level of market concentration at home and destination markets. As in other specifications, we also include main effects and interactions (INT) between these variables as well as county-by-year and bank fixed-effect. As in previous specifications standard errors are clustered at the county level.

We compute and plot the marginal effects of lending distance on changes in bank lending using estimates obtained from an OLS regression of specification (4) and setting the levels of market concentration at two standard deviations above- and below-average. The results, presented in Panel B of Figure 9, reinforce the idea that the boom-bust cycle in the marginal effects of lending distance is more pronounced when local branch markets are more competitive and when destination markets are less competitive. For instance, the plot on the left indicates that the marginal effects of lending distances on bank loan growth (red line) are larger in 2006 and 2007 for banks that are exposed to greater competitive pressures in their home markets.

A likely reason why banks in competitive markets stretch into distant lending, as the evidence above shows, is that heightened competition makes additional local lending riskier and less profitable in the boom. To explore this idea, we use the SBA data and estimate the sensitivity of chargeoffs in the market where the borrower is located to the local lending market concentration, and plot the results in Figure 10. We find that loans made between 2005 and 2008 in more competitive banking markets experienced relatively greater charge-offs, but not before or after this period. This evidence suggests that local lending opportunities were riskier and thus less profitable during the boom, which in turn could explain why lenders instead venture into more distant markets (where they also experience higher charge-offs, as we show in Section 3). In sum, the results suggest

that when lenders face more competition and diminishing profitable opportunities in their home markets, they tend to extend credit to distant borrowers.

\section{B. Outflows, Inflows or Both}

We have shown that in booms, lending flows from counties that have high bank competition and into counties that have high bank concentration. But are flows largely unidirectional? One could imagine flows in both directions, if all banks thought expansionary periods are an opportune 
moment to diversify lending.

To check this, we create a measure for the relative competitiveness between two counties that have any small business lending flows between them. Specifically, we compute, HHIShare = $\frac{H H I_{c 1}}{H H I_{c 1}+H H I_{c 2}}$ where $H H I_{c i}$ is the HHI of county $i=\{1,2\}$. If HHIShare is close to one, it indicates that county $c 1$ is relatively more concentrated (or less competitive) than county $c 2$ and, conversely, if HHIShare is close to zero, it indicates that $c 1$ is relatively less concentrated and more competitive than county $c 2$. Next, we categorize counties into those that have only lending inflows, only lending outflows, and have both in- and outflows, during the calendar year 2005, and plot the associated histogram in Figure 11. 14 As the figure shows, most county pairs have only inflows (grey distribution) or only outflows (yellow distribution), consistent with the notion that flows are largely unidirectional. Furthermore, the number of counties that have only inflows rises steadily with HHIShare (as $c 1$ becomes relatively less competitive), while the number with only outflows falls steadily with HHIShare. As might be expected, the relatively small number with two-way flows peaks when the HHIShare is 0.5. In sum, lending flows are largely unidirectional, and go from more competitive banking areas to more concentrated banking areas.

\section{Robustness: Alternative Indicators of Competition in Home and Destination Markets}

High concentration in an industry or region need not imply low competition - it could just mean that a more efficient producer has grabbed more market share. We therefore consider two alternative and more exogenous indicators of bank competition. First, we follow a broad literature that exploits the timing of adoption of interstate banking deregulation as a shock to competition in the banking industry (Bushman, Hendricks, and Williams, 2016, Cetorelli and Strahan, 2006; Jayaratne and Strahan, 1996; Kroszner and Strahan, 1996; Stiroh and Strahan, 2003) (e.g. Bushman, Hendricks, and Williams, 2016; Cetorelli and Strahan, 2006; Jayaratne and Strahan, 1996; Kroszner and Strahan, 1999; Stiroh and Strahan, 2003). Following these papers, we use the natural log of the years between 1996 and the year when the loan origination state's banking market was deregulated as a measure of competition. The idea is that, in states where deregulation occurred earlier, outof-state banks had more time to enter and ramp up competition. Second, we explore a large bank's entry into a local market (typically through M\&A). For a large bank, the competitive situation in any specific local market (i.e., a branch's county) is unlikely to drive the M\&A decision. But at the county-level, the entry of a large bank with a different business model and deep pockets is likely to disrupt local bank competition 15 Thus, we create an indicator that takes the value of one in the two years following the year in which a county sees a 5-percentage points increase in the deposit market share of a large bank (defined as a bank holding company whose total assets exceed $\$ 50$ billion). Such an increase suggests that a large bank either acquired another bank with local operations or significantly grew their operations in that county, both suggesting a more aggressive

\footnotetext{
${ }^{14}$ The histogram is very similar when we use other years in the sample.

${ }^{15}$ In the Online Appendix, we further gauge robustness of the results by using the HHI based on market shares in the deposit market (Table IA.9) and the penetration of shadow banks in the local mortgage market (Table IA.10) as alternative measures of competition.
} 
competitive environment in the two years that followed the large bank entry.

We report the results for the first alternative competition proxy in Table 6. In Columns (1), (3) and (5), we find that a longer time period since deregulation in the destination market (more competition) is associated with a less amplified cyclical pattern in lending distance. The results in Columns (2) and (4) suggest the opposite is true for the home market; here a longer time period since deregulation (more competition) is associated with a more amplified boom bust cycle in lending distance, consistent with the results in Table 5. Note that in Column (6), where the credit cycle measure is spreads, the relevant coefficient is significant, albeit with the opposite sign to that predicted.

We report the results for the second alternative competition proxy in Table 7 . The results of Columns (2), (4), and (6) show that when a large bank enters the home markets of other banks, the cyclical pattern in lending distance is substantially amplified as local banks react to the increased competitive pressures in their home markets by going the extra mile and increasing their distant lending during expansionary periods. Similarly, the results in Columns (1) and (3) suggest that distant lending increases less during expansionary periods in borrowers (or destination) counties when a large bank enters or increases its presence, consistent with the idea that banks avoid distant lending to counties with high or increased competitive pressures. We do not, however, find a significant effect in Column (5) when cyclicality is measured by spreads. Overall, our findings suggest that interbank competition is a catalyst for banks' cyclical distance lending. When banks face fierce competition in their local branch markets and economic conditions are expansionary, they are more likely to step outside their local areas and make distant loans. The flip side of such behavior is that when economic and credit conditions take a turn for the worse, these lenders become more conservative and focus on their core markets by disproportionately cutting lending to distant borrowers.

\section{Possible Explanations}

Let us now discuss possible explanations. Since distance lending took off between 2004 and 2007 , it is fair to ask whether changes in the overall economic environment over this period caused the surge in distance lending. We first explore such changes and then consider the role of moral hazard.

\section{A. Changes in Environment}

Perhaps banks had a lower cost of financing loans in more competitive areas, and therefore could make lower return loans (that is, riskier ones for the same interest rate) and still turn a profit? We compute two measures of banks' funding cost. First, DSS (2017) show retail (core) deposits comprise more than $70 \%$ of bank liabilities and that average equity ratios hover around $10 \%$, suggesting that a large portion of a bank's cost of capital is its retail deposit interest rate. To gauge whether banks' cost of capital was declining at the same time that lending distances were 
expanding, we compute banks' average interest expense, which is total interest expense (including interest expense on deposits, wholesale funding, and other liabilities) divided by total assets. We also obtain from RateWatch the average advertised rate of one-year certificates of deposit with a minimum deposit of $\$ 10,000$. Both measures (see Figure IA.10) suggest that banks' average cost of funding increased between 2004 and 2007 and declined thereafter. Recall that the Federal Reserve started raising rates in mid-2004 and continued doing so by 25 basis points every quarter until mid-2006, so the period of rising distance lending was also a period of rising interest rates, which the plots corroborate. The Fed started cutting rates with the onset of the financial crisis, but this decline coincides with a retrenchment in distance lending (not an increase).

It may be that the banks that extended lending distances were the ones with a particularly low cost of funding. To test this formally, we re-estimate specification (1) including the interaction between our measures of the banks' cost of funding, the lending distance, and the business cycle indicators in the baseline specification. We present the results in Table 8. They suggest instead that banks with greater overall costs of funding were more likely to increase distant lending during expansionary periods and retrench during subsequent recessions. We will suggest an explanation for this finding shortly, but distance lending is clearly not driven by a lower cost of capital, indeed quite the opposite.

Dell'Ariccia and Marquez (2006) show that when there are many competing banks, the nature of the equilibrium (careful bank screening and lending only to high quality borrowers versus little screening and "pooled" lending to borrowers of varying credit quality) depends on the entry rates of new borrowers, the degree of competition, and the cost of bank funding. It may well be that there were many more new borrowers entering as the economy strengthened from 2004 to 2007, causing banks to move to the "pooling" equilibrium with little screening. However, Dell'Ariccia and Marquez (2006) also argue that in more competitive markets and as banks' cost of funding goes up, which is what we see for counties in which banks reach for distance, the screening equilibrium is likely to persist 16 Thus, the theoretical argument suggesting the pooled equilibrium with little screening might prevail in good times is unlikely to explain our findings of differences between competitive and concentrated banking areas.

\section{B. Forms of Moral Hazard}

Moral hazard is another potential explanation for our findings, but it comes in different forms. Given banks are highly levered, the classic form of bank moral hazard is their incentive to shift risk to depositors, or if depositors are insured by the government, to the taxpayer. As Keeley (1990) argues, this incentive is particularly pronounced when the degree of bank competition increases, thus eroding the bank's franchise value or market capital. Similarly, Hellmann, Murdock, and Stiglitz (2000) argue that bank competition can undermine prudent bank behavior and induce banks to

\footnotetext{
${ }^{16}$ Intuitively, when there are many banks, each bank knows less about the overall market, and so faces a greater possibility of adverse selection. Its preference for the screened equilibrium increases. Similarly, pooled lending required disproportionately more funds from a bank than screened lending. So when the bank's cost of funding goes up, its preference for screened lending increases.
} 
take excessive risks 17 It may be that bank franchise values are lower in the more competitive counties, but US bank market-to-book ratios, a proxy for franchise (or market) value, rose from 2002 to 2003 and then stayed high until the financial crisis (Bogdanova, Fender, and Takáts, 2018). Moral hazard between shareholders and the taxpayer is therefore unlikely to explain the timing of the documented surge in distant lending. Moreover, if risk-shifting moral hazard were the key influence, banks could have made risky loans locally - why search for risk far away? Finally, if indeed banks were actively looking to shift risk, they would have demanded higher rates on the risky distant loans they made, which we do not find.

Nevertheless, we examine whether banks with lower Tier 1 capital ratios in 2005 are associated with more distant lending over the cycle. The results presented in Table IA.11 do not produce a clear pattern: Depending on the measure of the cycle, the coefficient is either insignificant, suggests lower capital reduces distant lending over the cycle, or indicates it increases it. Of course, these estimates should be interpreted with caution because bank capitalization is a highly endogenous variable. Thus, it is hard to draw clear inferences but based on the evidence in Table IA.11 it is unlikely that risk-shifting moral hazard explains our results on distance.

Another form of moral hazard arises between loan officers and management, especially when loan officers are physically far from top management oversight. Perhaps loan officers in competitive areas are worried about the lower returns to local lending induced by competition (a phenomenon we have documented in the pre-crisis years) and in response make distant loans in less competitive areas. Ideally, they would admit to having few reasonable nearby lending opportunities and transfer excess funds to headquarters, but that might mean they lose their jobs. According to this explanation then, it is loan officer or branch manager career concerns that cause them to lend at a distance.

The problem with this story is that distance lending is relatively easy for top management to monitor. It is implausible to think that top management cannot see that a loan officer is making loans outside her bailiwick - after all, if researchers can see distance (after the public release of bank data), so can bank management with real time access. To nevertheless explore the role of this form of moral hazard, we restrict the sample to small banks that have all their branches in the same county. For these banks, top management is not physically distant from loan officers and hence it should be better able to monitor distance lending and also have a better sense for local lending opportunities. Yet, as Table IA.12 in the Online Appendix shows, we still find the effect of local competition on the tendency to make more distant loans during the expansion in this sample, which makes it unlikely that loan officer/branch manager moral hazard drives the results.

A final form of moral hazard is the agency problem between top management and long-term shareholders. Relative performance evaluation is more feasible and thus more likely in competitive banking areas. It strongly incentivizes bank CEOs but also promotes short-termism in bank management (e.g., Agarwal and Ben-David, 2014, Rajan, 1994, Stein, 1989). With relative performance evaluation, it may be difficult for a CEO to sit on un-lent cash if competitors seem to have

\footnotetext{
${ }^{17}$ On the other hand, Boyd and De Nicolo 2005 ) argue that concentration in banking markets could encourage higher interest rates, which, in turn, could heighten moral hazard concerns with bank borrowers.
} 
no difficulty booking fees by making loans. The incentives for top management to generate loan growth are especially pronounced when the bank is publicly owned (Falato and Scharfstein, 2016); shareholders can track overall loan growth, fees, and short-term profitability reported in quarterly numbers, yet have little data on the characteristics or quality of loans being made. In such situations, top bank management has an incentive to increase loan volume and book origination fees to boost profits. It does not, however, have a direct incentive to take on more risk - which it could do locally - though this may be a collateral consequence of boosting loan growth at a distance.

Thus, a potential reason why CEOs of banks situated in more competitive areas look to make more distant loans is that the profitability of nearby loans is low, and distant loans in less competitive areas may, at least ex ante, seem more profitable. Management, driven by the need to look good over the short term, should have no difficulty ordering loan officers to stretch for distance, especially if the bank's internal controls are weak. This explanation still leaves an important question: Why were these incentives particularly pronounced in the period from 2004 to 2007 when the Fed was raising interest rates? For that, we have to turn to the important work of DSS (2017).

\section{Changes in the Environment that Augment Moral Hazard}

DSS (2017) show that when the Fed raises interest rates, banks with market power over depositors do not pass on the rate increases. Although they lose some deposits as a result, and therefore have lower loan growth, this decision maximizes profits. We conjecture that while many depositors stay with their banks, perhaps because they enjoy other benefits such as proximity to the branch or because they do not want to incur the search costs, some will look for higher rates elsewhere. In contrast, banks in competitive areas are forced to raise rates. For them, the elasticity of deposit flows to interest rates is much higher, which makes holding the deposit rate in the face of Fed rate increases unappealing from a profit-maximization standpoint: the additional deposit spread that they make on deposits they keep likely does not compensate for the deposit spread they lose on the deposits that flee to neighboring banks. Moreover, by raising rates in such times, they attract footloose deposits from banks in concentrated areas, where banks have not raised rates. We conjecture that these differential deposit flows exacerbate the moral hazard problem that gives rise to distance lending.

The idea is that, even though rising policy interest rates reduce loan demand similarly across concentrated and competitive areas, deposit growth is relatively higher in competitive areas, partly because of the direct effect of raising savings when banks in such areas pass through higher policy rates to depositors and partly because these banks attract deposits from elsewhere. Indeed, this is what Figure 12 shows, for the period 2004-2007, when we plot deposit growth rates across areas in different concentration bins ${ }^{18}$ Thus, as the Fed raises interest rates, the excess supply of funds (deposits minus local loan demand) is relatively higher in competitive banking areas than in areas where banking is concentrated. But the competitive areas are also the ones where short-horizon

\footnotetext{
${ }^{18} \mathrm{We}$ also find that deposit growth across areas is flatter in the three years before this period (before policy interest rates were increased) and in the three years post crisis (2009-2012) when policy rates were cut to zero.
} 
bank management feels the need to redeploy the excess "hot" supply of deposits into loans, and hence it may look to make loans in distant, less competitive areas where there is potentially an unmet loan demand. Thus, as policy rates go up, banks in competitive areas where deposit rates go up the most tend to lend at a greater distance, which is precisely what we see in Table 5. Ironically, this hypothesis suggests that, even as the Fed raises interest rates, lending is reallocated to the detriment of overall credit quality, as banks in concentrated areas pull back from proximate loans whereas banks in competitive areas make more distant loans to these places where they have less of a comparative advantage.

In sum, our hypothesis is that managerial short-termism, heightened by a surge in deposit inflows in competitive areas "burning a hole" in bank manager pockets, exacerbated the search for distant lending opportunities in the period before the financial crisis. As rates came down with the onset of the crisis, the surge reversed, and banks cut back on distant lending. 19 We now turn to evidence consistent with this hypothesis.

\section{Evidence for "burning a hole in your pocket" short termism}

In this section, we first provide evidence that banks' deposit side actions are associated with distance lending. Then, we show that banks, for which managerial short-termism is likely more prevalent, are precisely the ones that stretch for distance in the pre-crisis years. We offer these two pieces of evidence in support of the hypothesis we just articulated.

\section{A. Deposit Side Behavior and Distance Lending}

We compute interest expense betas following DSS (2017), These interest expense betas measure the sensitivity of deposit interest rates paid by banks to changes in the Fed Funds rate. A low interest expense beta is a measure of a bank's market power to keep its deposit rates low when rates elsewhere go up. We compute the average interest expense beta of a destination county and the average interest expense beta of a bank in the origin county. As they reflect deposit competition or market power in destination and origin counties, we repeat the Table 6 analysis replacing the market concentration proxies by the respective average interest expense betas. The results, reported in Table 9, are consistent with our main results. We find that when the origin county has a greater interest expense beta (is more competitive for deposits), distant loans made from that county tends to be more procyclical. Conversely, distant loans made to a destination

\footnotetext{
${ }^{19}$ Our argument of increased short-termism in competitive areas could emanate from other channels than deposit shifts. For instance, the fall in bank profitability in competitive areas relative to concentrated areas as a result of higher deposit costs could, by itself, have prompted pro-cyclical distance lending from the competitive areas as banks there strove to increase profitability. Yet, as we have shown, even banks that were entirely located in a competitive county increased their distant lending. Shareholders would compare these banks with other similar banks located entirely in the county - deposit costs would have gone up for all, reducing profitability uniformly across banks. Relative performance evaluation and short termism could not explain the increased pressure to lend for such banks unless banks also had other ways of distinguishing themselves - such as additional deposit inflows that they could invest safely in cash (lower short-term profits) or lend (higher short-term profits).
} 
county tend to be more procyclical when it has a lower interest expense beta (is less competitive for deposits). This evidence suggests that counties, where banks raised interest paid to depositors faster as the Fed raised its policy rates, lent the excess funds they attracted, in part, to counties where banks did not raise deposit rates similarly.

Before going further, some comments are in order. First, our hypothesis does not imply or require that myopic bank management willfully makes bad loans or reduces profitability. They may in fact want to make the best and most profitable loans they can. The way moral hazard manifests is that, when they have exhausted local lending opportunities and still have plenty of unused funds, they do not allow the inflows to accumulate as cash or investments on their balance sheets. Instead, they venture beyond their traditional expertise and make loans in locations where they cannot assess risk well. Moral hazard suggests that bank managers in competitive areas do not cut deposit rates when they see money flooding in because they fear that their bank will be significantly less profitable than the competition (and thus be viewed as a relative underperformer) if they turn away deposits. Cutting deposit rates in competitive areas could also imply losing the spread on many existing deposits. Moreover, bank managers might genuinely believe that they have adequate lending opportunities.

Second, such an environment may not prevail every time the central bank normalizes rates. If the Fed raises policy rates rapidly so that loan demand plummets everywhere, there may be excess funds relative to loan demand in both competitive and concentrated areas. In this situation, it may be less attractive to make distant loans. The measured pace at which the Fed raised interest rates from 2004 to 2006 led a number of commentators to argue that the Fed had fallen behind the curve in moderating demand 20 So it may well be that the search for distance is less pronounced in other periods of monetary tightening.

Finally, DSS (2017) argue that aggregate deposit growth is typically lower when the Fed raises rates, which leads to the question why deposit growth does not burn a hole in bank pockets when the Fed is cutting rates. There are three related explanations. First, the Fed typically raises rates when the economy shows signs of overheating, and credit opportunities are getting saturated. This is precisely when a bank in a competitive area would have limited local lending opportunities and the possibility for new deposits "to burn a hole" would increase. In contrast, when the Fed cuts rates, credit is likely to be scarce, local borrowers likely seek credit, and hence there are likely more opportunities to make local loans. Second, as Rajan (1994) argues, in downturns, which is when the Fed cuts rates, there is far less competitive pressure on bank managers to show profitable lending. So bankers can be much more careful about credit volumes and credit quality. Finally, in the specific episode from 2004 to 2007, overall economic activity, and average deposit growth, continued to be quite strong even as the Fed raised rates. The "burning a hole" phenomenon due to the tilt in deposit flows would be even stronger under such circumstances.

\footnotetext{
${ }^{20}$ See, for example, Taylor (2007) and, in response, Bernanke 2010.
} 


\section{B. Evidence for Managerial Short-termism}

Falato and Scharfstein (2016) argue that managerial short-termism is likely to be more pronounced in publicly owned banks than in privately owned banks. Quarterly numbers such as loan growth and quarterly profits assume greater importance in publicly held banks, especially because shareholders do not see more detailed assessments of loan characteristics. In Table 10, Column (1), we estimate the baseline regression model in (1) after including a triple interaction term between the $\log$ of distance, the business cycle indicator (HP filtered real GDP), and an indicator that is equal to one if the bank is publicly listed (as well as all the double interactions, of course). To ensure that the results are not driven by the inclusion of large public banks whose size is not matched by that of any private bank or by small private banks that are smaller than any publicly-listed bank, we exclude large public banks whose total assets exceed those of the largest private bank and small private banks whose total assets are smaller than those of the smallest public banks in the dataset. The estimated coefficient of the triple interaction suggests distance lending is more cyclical for public banks.

Clearly, the more internal and external discretion top management has, the greater its ability to accede to short-term pressures. Ellul and Yerramilli (2013) create a risk management index (RMI) for a sample of bank holding companies based on whether they report having a chief risk officer, the chief risk officer's influence in the hierarchy, and whether there is an experienced board committee actively supervising risk management. The higher the RMI, the more constrained the CEO is in pursuing short term objectives. As before, we estimate a triple interaction term between the log of distance, the business cycle indicator (HP filtered real GDP), and the short-termism proxy. In Table 10, Column (2), the coefficient estimate of the triple interaction term shows that the cyclical increase in distance lending is lower for banks with a higher RMI, suggesting that distance lending is less responsive to the cycle when top management is more constraint.

We consider two more governance proxies. Under the assumption that Big- 4 auditors are more diligent than non-Big-4 auditors and that banks with Big-4 auditors have more stringent internal controls, we expect that top management at banks with Big-4 auditors is more constrained (DeFond and Zhang, 2014). In Column (3), we find banks audited by the Big-4 are less likely to exhibit the cyclical increase in distance lending. Similarly, bonus and option grant targets for CEOs can provide short-term incentives to achieve such targets even when it is at the expense of long-term value creation (e.g. Fahlenbrach and Stulz, 2011). To capture these incentives, we measure the percentage of variable pay in bonuses and options. We use the percentage of the CEO's 2005 pay in bonuses and options and interact it with the log of distance and the cycle. Table 10, Column (4) shows that the greater the CEO's variable compensation, the greater the cyclical increase in distance lending, as the short-termism hypothesis predicts.

In Column (5), we report results after including the triple interactions for all four short-termism proxies together in the same specification (along with all other interaction terms) and we find that the coefficients remain statistically significant and retain their signs, suggesting that each variable adds a dimension that is not entirely subsumed by the other variables. Of course, we cannot prove 
causality here. Managers that desire less discretion may stay private, empower risk managers, appoint Big-4 auditors, and take less variable compensation. Regardless of causality, there is an association between indicators of managerial short-termism and the cyclical increase in distance lending.

So far, we have separately argued for the effects of business cycle conditions, including rate hikes, differences in banking competition, and short-termism in driving the cyclical increase in distance lending. In Table 11, we bring it all together. We repeat the analysis of Table 6, Column (3), which includes the difference in local competition between destination and origin counties, but now we partition the sample based on the four measures of managerial short-termism that we examined above. The results indicate that the impact of local market competition in exacerbating the procyclicality of lending distance is more pronounced in banks whose managerial characteristics are more associated with managerial short-termism.

\section{The Role of Internal Capital Markets}

Our analyses to this point suggest that an important spur to distance lending is the lack of proximate lending opportunities in highly competitive areas, combined with excess liquidity and un-lent funds. Next, we examine whether banks that have the ability to redeploy such funds from branches facing significant competitive pressures to branches that are less exposed to fierce competition are less inclined to lend to distant borrowers. Such evidence would suggest that when there are outlets within the branch network for fresh deposits, they do not "burn a hole" in bank pockets.

A simple measure of dispersion of lending opportunities within a bank's branch network is the coefficient of variation of the lending HHI across the branch network of each bank. A large coefficient of variation of the level of market concentration across a branch network indicates significant dispersion in market concentration relative to the average level of market concentration of the bank. We use this dispersion (relative to the mean) as a proxy for a bank's ability to use its branch network to reallocate funds from areas with significant competitive pressures where lending opportunities are scarce and profit margins small to areas where they face lower competitive pressures.

We examine this conjecture by partitioning banks based on the coefficient of variation of the HHI of their local branch markets at the beginning of the sample period. Figure 13 plots average banklevel lending distances separately for banks with above- and below-median coefficient of variation of HHI. The plot suggests that the boom-bust cycle in lending distances only exists in the subset of banks whose HHI dispersion relative to the mean is low. In this group, average bank lending distances approximately double between 2003 and 2007 and subsequently decline between 2008 and 201221

To further examine the role of internal capital markets in shaping the cyclical relation between

\footnotetext{
${ }^{21}$ In Figure IA.11 of the Online Appendix, we further split the group with a low HHI coefficient of variation into those banks with uniformly low HHI across its branches and those with uniformly high HHI across its branches. Confirming our expectations, we find that the boom-bust cycle in lending distances is more pronounced in the subset of banks with low coefficient of variation exposed to uniformly low market concentration.
} 
lending distance and changes in bank lending, we implement a specification similar to equation (4) in which we use the triple interaction between lending distances, business cycle indicators, and the coefficient of variation of HHI as the main independent variable of interest. We report these results in Table 12. The estimated coefficient on the triple interactions suggest that the effect of the business cycle on the cyclical increase in distance lending is more pronounced when the coefficient of variation of HHI between the bank's accessible markets is small 22

Thus, when a bank has more lending opportunities within its branch network and can redeploy funds, it is not as prone to venturing out of its comfort zone to lend at a distance. This is yet another indicator that the fundamental agency problem is not between bank managers and loan officers - else we should see loan officers in branches located in competitive counties stretch to lend their surplus funds at a distance, rather than hand them to the bank's branch network to deploy elsewhere.

\section{Lending Distance and Systemic Risk}

Does any of this matter? After all, small business lending is a small part of most bank portfolios. If the lending patterns we have documented are not part of a broader pattern of risk taking, they are still interesting, but of more modest importance for regulation and supervision, or economywide policy making. It seems plausible, though, that the "burning a hole" mechanism at work here - greater deposit inflows (or, more generally, access to liquidity) prompting more indiscriminate lending by myopic bank management in competitive banking areas - is more generally applicable than just in the case of small business lending. The stretch to lend at a distance may just be a signal that the bank is more broadly pushing to generate activity and fees, even if it means going beyond its areas of competence. This is what we now examine.

\section{A. Lending Distances and Banks' Systemic Risk}

Our first approach is to see whether lenders that experienced overall worse outcomes during the 2007-2009 period (not just from small business loans) were also those that originated relatively more loans to distant borrowers in the run-up to the 2007-2009 financial crisis and subsequently pulled back. This pattern would suggest that the short-term-oriented, liquidity-flush banks that lend more to distant small business borrowers are also more willing to take other risks that are difficult to evaluate and quantify and which, later, result in large losses. With the onset of the downturn, these losses, as well as the equalization in deposits as policy rates came down, created significant balance-sheet pressures that induced these lenders to de-lever and retreat to the safety of local markets (e.g., consistent with the pattern observed in the cross-border lending in De Haas and Van Horen 2013 and Giannetti and Laeven 2012).

\footnotetext{
${ }^{22}$ This result is related to Cetorelli and Goldberg (2012), Gilje, Loutskina, and Strahan (2016) and especially Cortés and Strahan (2017), showing that commercial banks actively redeploy resources within their areas of operation in response to external shocks but show a preference for their core markets in doing so. Our result is slightly different in that we show that some banks never need to venture outside their core.
} 
We begin by studying banks' loan losses more broadly, not just from small business loans. For this analysis, we stratify banks based on the median of the distribution of nonperforming loan ratios computed over the 2007-2009 period and plot average distances over the sample period for above- and below-median banks as ranked by their nonperforming loan ratio. The results, shown in Figure 14, are striking: above-median NPL banks exhibit a very pronounced boom-bust cycle in the average bank-level lending distances. By contrast, the average bank-level lending distances of below-median banks remain relatively steady from 2002 to 2010 and increase slightly thereafter. These results are consistent with the notion that banks that went the extra mile in small business lending also took other risks that led them to experience larger loan losses overall.

To formally examine this association, we implement a specification similar to equation (4) to examine the interaction between the nonperforming loan (NPL) ratios, lending distance, and the business cycle indicators. We report the results in Table 13. We find that lending distances are more positively (negatively) associated with changes in bank lending during expansionary (recessionary) periods, respectively. More importantly, the triple interaction between the NPL ratios, lending distances, and business cycle indicators reveals that banks with greater loan delinquencies also stretched out more over the business cycle to lend at a distance. For example, the results of Column (1) of Table 13 suggest that a one-standard deviation increase in the NPL ratio is associated with an increase of the interaction between lending distance and the detrended GDP of approximately $7 \%$ (0.002/0.027). These magnitudes indicate that banks experiencing greater loan losses exhibit also a more pronounced boom-bust cycle in distance lending. In the other columns of Table 13, we obtain qualitatively similar results for the other cycle variables (though with larger economic magnitudes). In Figure IA.13 in the Online Appendix, we again map out these estimates over time and show that banks with greater nonperforming loan ratios between 2007 and 2009 show greater annual elasticities of changes in bank lending with respect to lending distances in the immediate years before the financial crisis, so the findings are coming from the years that we would expect.

\section{B. Lending Distance and Returns-Based Measures of Tail Risk}

The nonperforming loan ratio of each bank between 2007 and 2009 likely captures both idiosyncratic and systematic risks that these banks carried in their lending portfolios ${ }^{23}$ From a regulatory perspective, however, the documented cyclicality in lending distances is even more important if it is representative of exposures to systemic risks that were building up in the financial system before the crisis.

To gauge this possibility, we use a measure based on stock returns to capture the exposure of a bank to aggregate tail shocks. We follow Acharya et al. (2017) and Meiselman et al. (2020) and measure exposure to systematic risks as the average stock return of each bank stock during bad

\footnotetext{
${ }^{23}$ In addition, a number of recent studies (Behn, Haselmann, and Vig, 2016, Begley, Purnanandam, and Zheng, 2017, Farinha, Rebelo, and Blattner, 2018, Plosser and Santos, 2018, Granja and Leuz, 2018) suggest that banks strategically understate risk exposures and underreport loan losses in response to capital constraints and regulatory incentives. This evidence suggests that the nonperforming loan ratio measured during the crisis may not accurately reflect differences in banks' underlying portfolio risks.
} 
days throughout the financial crisis. We define bad days as days in which the return on the market and the Fama/French banking industry portfolio are on the bottom 5 percentiles of the empirical distributions generated by daily stock returns during 1926 - 2015. Acharya et al. (2017) find that this measure is related to a financial institution's propensity to be undercapitalized when a system as a whole is undercapitalized, a concept that they refer to as the systemic expected shortfall. We explore whether banks that investors perceive as being exposed, on average, to more systematic risk, also exhibit more pronounced cyclical fluctuations in their lending distances. The goal is not to claim that cyclicality in small business lending distance is a driver of systematic risk, but the circumstances that lead banks to engage in greater procyclical distance lending are also the circumstances that lead them to take greater systematic tail risk.

In Table 14, Panel A we report summary statistics of the main variables used in this analysis. We measure lending distance cyclicality as the coefficient of correlation over the entire sample period between the business cycle indicator and the average lending distance of each bank. Average stock market returns in bad bank (market) days is $-3.3 \%$ (-3.9\%). Importantly, there is significant variation in the stock market performance of banks during these days suggesting considerable crosssectional heterogeneity in bank exposure to systemic risks.

We use a specification similar to that of Meiselman et al. (2020) to examine whether lending distance procyclicality is positively correlated with the return-based measure of systematic risk in the cross-section of banks. We report the results of this analysis in Panel B of Table 14. The results are indicative that a bank's propensity to accept exposures to tail risks is associated with more pronounced boom-bust cycles in lending distances. For instance, the results of Column (1) suggest that when the coefficient of correlation for distance lending increases from zero to one, the average returns on bad bank days decrease approximately one percentage point, which is approximately one standard deviation of the distribution of the dependent variable. The results reported in the other columns of Table 14, Panel B further support this association between procyclicality in lending distances and systemic risks.

In sum, the evidence suggest that greater lending distances are reflective of more generalized risk taking by banks, which in turn relates to surges in deposits, interbank competition, and bank short-termism. Distance lending may well be the proverbial canary in the coal mine.

\section{Discussion of Results and their Relation to the Literature}

The most important contribution of the paper is to show how short-termism in competitive areas of banking is exacerbated when banks receive a substantial inflow of liquidity. The inflow of liquidity may well be an unintended consequence of the Federal Reserve normalizing interest rates, and banks responding differentially to it based on their market power over proximate depositors, as shown in DSS (2017), Indeed, this differential response may open up lending opportunities in regions where banks have substantial market power - their desire to squeeze depositors may cause them to forego additional lending. Unfortunately, it seems that distant banks are poorly positioned 
to take advantage of these opportunities in concentrated areas. More generally, we show distance lending to small businesses occurs in concert with other bank risk taking, possibly taken by myopic bank management in order to boost short-term performance. The sum of these exposures in turn contributes to enhanced bank risk, and since the common driver of these is enhanced liquidity inflows, also to enhanced systemic risk.

Which of these elements are essential? Without managers' short horizons, and without bank competition making local lending opportunities scarce, there would be no incentive to stretch for distance. Without monetary tightening at a measured pace in an overheating economy, there would be no liquidity surges in some areas nor would there be seemingly unsatisfied lending opportunities in others. Interestingly, this suggests a simple rearrangement of deposit liquidity in the midst of a boom can fuel lending excesses - perhaps the Fed might have headed off the excess lending by tightening faster as suggested by Taylor (2007), while, no doubt, incurring the greater risk of a recession. In contrast, substantial aggregate liquidity infusion might do little in the middle of a recession, when no one else is lending, and there is little competitive pressure on short-horizon bank management - hence the "pushing on a string" analogy central bankers are fond of.

By putting the above elements into a cogent explanation, our paper contributes to and is related to findings in a number of areas. First, a series of papers show that geographic distance still plays a major role in lending decisions. For instance, Agarwal and Hauswald (2010) show that shorter physical distance improves the ability of lenders to produce soft information and extend credit to small businesses, Granja, Matvos, and Seru (2017) show that geographic proximity is a significant determinant of who acquires failed banks in the economy, and Nguyen (2019) finds that bank branch closures are associated with declines in small business lending. We uncover a significant cyclical component to such distances, and also find that banks going the extra mile indeed take extra risks. Proximity still seems to matter in controlling risks.

Second, a number of studies examine the cyclicality of risk taking in the economy. Dell'Ariccia and Marquez (2006), Kopytov (2019), Rajan (1994), Ruckes (2004), and Zentefis (2020) show how cyclical lending standards can emerge in equilibrium in the economy 24 A series of papers (e.g. Cerutti et al., 2015, De Haas and Van Horen, 2013, Dell'Ariccia, Igan, and Laeven, 2012, Giannetti and Laeven, 2012; Ioannidou, Ongena, and Peydró, 2015; Jiménez, Ongena, Peydró, and Saurina, 2014; Kleimeier et al., 2013; Lisowsky et al., 2017; Maddaloni and Peydró, 2010; Mian and Sufi, 2009; Rajan and Ramcharan, 2015) provide empirical evidence of the cyclicality of credit standards. In domestic markets, Degryse et al. (2018) and Presbitero et al. (2014), suggest banks are quicker to drop their distant clients in a downturn. Perhaps most relevant to our paper, Falato and Scharfstein (2016) suggest that managerial short-termism is an important driver of bank risk taking. We add to this literature by showing that macro events (Fed tightening) combined with

\footnotetext{
${ }^{24}$ In an interesting recent paper, Kopytov $(2019)$ describes why lending distance might increase as the cycle gets long in the tooth - essentially lending margins erode, therefore loans are riskier, and diversification (and hence distant loans) becomes more important for banks to avoid the expected costs of distress. Presumably margins erode more in competitive areas, hence there should be greater search for distance in those areas. Kopytov's model would suggest an increase in diversification in all areas, but particularly in competitive ones. Our evidence suggests an increase in distance primarily in competitive areas.
} 
microeconomic differences across regions (in competition and bank market power) and across banks (in their management's short horizons) can enhance the cyclicality of lending standards in the small business lending market.

We also show that banks that are diversified across areas with differing degrees of competition do not succumb to such distorted behavior. This may explain the finding in Morgan, Rime, and Strahan (2004) that greater banking integration spurred by interstate banking deregulation in the United States reduced business cycle volatility at the state-level. Our findings also suggest that a focus on interbank competition and the incentives thereof are essential to complement explanations of boom-bust episodes relying on over-optimism or other forms of irrationality. It would otherwise be hard to explain why specific types of banks as well as banks in certain areas seem more immune to the frenzy that overtakes bank lending episodically.

Our finding that a sharp increase in lending to distant small businesses is indicative of a generalized increase in a bank's risk taking could be useful to bank supervisors. Since lending distance is easily measurable, it is a metric that bank supervisors could track as they monitor lending standards in the economy. Of course, we realize that doing so would still be subject to Goodhart's Law, i.e., as soon as supervisors start tracking lending distance, banks will behave in ways that make it less useful. Moreover, to the extent that banks push new lending technologies to their limit, it could give them a better understanding of these technologies, and a greater ability to lend at a distance during normal times. In other words, excess distance lending may expand banks' normal lending potential as well as accelerate the secular trend in lending distance. Until this issue is further explored, any supervisory intervention needs to be measured.

Finally, our paper suggests that monetary policy normalization may, under some circumstances, increase distortions in the banking system. We do not argue that policy rates should not be raised from low prevailing rates, but that supervisors should not become complacent believing banks' credit quality will only improve as policy rates normalize. Indeed, our evidence raises the question whether a measured pace of tightening could create more distortions than either no tightening or a rapid tightening. More research is clearly needed in exploring the interaction between macro-policy and micro-incentives.

\section{REFERENCES}

Acharya, Viral V., Lasse H. Pedersen, Thomas Philippon, and Matthew Richardson, 2017, Measuring Systemic Risk, The Review of Financial Studies 30, 2-47.

Agarwal, Sumit, and Itzhak Ben-David, 2014, Do Loan Officers' Incentives Lead to Lax Lending Standards? (National Bureau of Economic Research). 
Agarwal, Sumit, and Robert Hauswald, 2010, Distance and Private Information in Lending, The Review of Financial Studies 23, 2757-2788.

Aliber, Robert Z., and Charles P. Kindleberger, 2017, Manias, Panics, and Crashes: A History of Financial Crises (Springer).

Begley, Taylor A., Amiyatosh Purnanandam, and Kuncheng Zheng, 2017, The Strategic Underreporting of Bank Risk, The Review of Financial Studies 30, 3376-3415.

Behn, Markus, Rainer F. H. Haselmann, and Vikrant Vig, 2016, The Limits of Model-based Regulation, SSRN Scholarly Paper ID 2804598, Social Science Research Network, Rochester, NY.

Berger, Allen N., and Gregory F. Udell, 1995, Relationship Lending and Lines of Credit in Small Firm Finance, The Journal of Business 68, 351-381.

Bernanke, Ben S., 2010, Monetary policy and the housing bubble: A speech at the Annual Meeting of the American Economic Association, Atlanta, Georgia, January 3, 2010, Technical Report 499, Board of Governors of the Federal Reserve System (U.S.).

Bogdanova, Bilyana, Ingo Fender, and Előd Takáts, 2018, The ABCs of bank PBRs, BIS Quarterly Review, March .

Boyd, John H., and Gianni De Nicolo, 2005, The theory of bank risk taking and competition revisited, The Journal of finance 60, 1329-1343.

Brevoort, Kenneth P., and John D. Wolken, 2008, Does distance matter in banking?, Technical report, Board of Governors of the Federal Reserve System (US).

Brown, J. David, and John S. Earle, 2017, Finance and growth at the firm level: Evidence from SBA loans, The Journal of Finance 72, 1039-1080.

Bushman, Robert M., Bradley E. Hendricks, and Christopher D. Williams, 2016, Bank competition: Measurement, decision-making, and risk-taking, Journal of Accounting Research 54, 777-826.

Cerutti, Eugenio, Galina Hale, and Camelia Minoiu, 2015, Financial crises and the composition of cross-border lending, Journal of International Money and Finance 52, 60-81. 
Cetorelli, Nicola, and Linda S. Goldberg, 2012, Follow the money: Quantifying domestic effects of foreign bank shocks in the great recession, American Economic Review 102, 213-18.

Cetorelli, Nicola, and Philip E. Strahan, 2006, Finance as a barrier to entry: Bank competition and industry structure in local US markets, The Journal of Finance 61, 437-461.

Cortés, Kristle Romero, and Philip E. Strahan, 2017, Tracing out capital flows: How financially integrated banks respond to natural disasters, Journal of Financial Economics 125, 182-199.

De Haas, Ralph, and Neeltje Van Horen, 2013, Running for the exit? International bank lending during a financial crisis, The Review of Financial Studies 26, 244-285.

DeFond, Mark, and Jieying Zhang, 2014, A review of archival auditing research, Journal of accounting and economics 58, 275-326.

Degryse, Hans, Kent Matthews, and Tianshu Zhao, 2018, SMEs and access to bank credit: Evidence on the regional propagation of the financial crisis in the UK, Journal of Financial Stability 38, $53-70$.

Degryse, Hans, and Steven Ongena, 2005, Distance, lending relationships, and competition, The Journal of Finance 60, 231-266.

Dell'Ariccia, Giovanni, Deniz Igan, and Luc UC Laeven, 2012, Credit booms and lending standards: Evidence from the subprime mortgage market, Journal of Money, Credit and Banking 44, 367384.

Dell'Ariccia, Giovanni, and Robert Marquez, 2006, Lending booms and lending standards, The journal of finance 61, 2511-2546.

Diamond, Douglas W., 1984, Financial intermediation and delegated monitoring, The review of economic studies 51, 393-414.

Diamond, Douglas W., 1991, Monitoring and reputation: The choice between bank loans and directly placed debt, Journal of political Economy 99, 689-721.

Drechsler, Itamar, Alexi Savov, and Philipp Schnabl, 2017, The deposits channel of monetary policy, The Quarterly Journal of Economics 132, 1819-1876. 
Drechsler, Itamar, Alexi Savov, and Philipp Schnabl, 2019, How monetary policy shaped the housing boom, Technical report, National Bureau of Economic Research.

Ellul, Andrew, and Vijay Yerramilli, 2013, Stronger risk controls, lower risk: Evidence from US bank holding companies, The Journal of Finance 68, 1757-1803.

Fahlenbrach, Rüdiger, and René M. Stulz, 2011, Bank CEO incentives and the credit crisis, Journal of financial economics 99, 11-26.

Falato, Antonio, and David Scharfstein, 2016, The stock market and bank risk-taking, Technical report, National Bureau of Economic Research.

Farinha, Luísa, Francisca Rebelo, and Laura Blattner, 2018, When losses turn into loans: The cost of undercapitalized banks, Technical report, Banco de Portugal, Economics and Research Department.

Gennaioli, Nicola, Andrei Shleifer, and Robert Vishny, 2015, Neglected risks: The psychology of financial crises, American Economic Review 105, 310-14.

Giannetti, Mariassunta, and Luc Laeven, 2012, The flight home effect: Evidence from the syndicated loan market during financial crises, Journal of Financial Economics 104, 23-43.

Gilje, Erik P., Elena Loutskina, and Philip E. Strahan, 2016, Exporting liquidity: Branch banking and financial integration, The Journal of Finance 71, 1159-1184.

Granja, João, and Christian Leuz, 2018, The death of a regulator: Strict supervision, bank lending and business activity, Technical report, National Bureau of Economic Research.

Granja, Joao, Gregor Matvos, and Amit Seru, 2017, Selling failed banks, The Journal of Finance $72,1723-1784$.

Hellmann, Thomas F., Kevin C. Murdock, and Joseph E. Stiglitz, 2000, Liberalization, moral hazard in banking, and prudential regulation: Are capital requirements enough?, American economic review $90,147-165$.

Ioannidou, Vasso, Steven Ongena, and José-Luis Peydró, 2015, Monetary policy, risk-taking, and pricing: Evidence from a quasi-natural experiment, Review of Finance 19, 95-144. 
James, Christopher, 1987, Some evidence on the uniqueness of bank loans, Journal of financial economics 19, 217-235.

Jayaratne, Jith, and Philip E. Strahan, 1996, The finance-growth nexus: Evidence from bank branch deregulation, The Quarterly Journal of Economics 111, 639-670.

Jiménez, Gabriel, Steven Ongena, José-Luis Peydró, and Jesús Saurina, 2014, Hazardous times for monetary policy: What do twenty-three million bank loans say about the effects of monetary policy on credit risk-taking?, Econometrica 82, 463-505.

Keeley, Michael C., 1990, Deposit insurance, risk, and market power in banking, The American economic review 1183-1200.

Kleimeier, Stefanie, Harald Sander, and Sylvia Heuchemer, 2013, Financial crises and cross-border banking: New evidence, Journal of International Money and Finance 32, 884-915.

Kopytov, Alexandr, 2019, Financial networks over the business cycle, Unpublished working paper .

Kroszner, Randall S., and Philip E. Strahan, 1996, Regulatory incentives and the thrift crisis: Dividends, mutual-to-stock conversions, and financial distress, the Journal of Finance 51, 12851319.

Liberti, José María, and Mitchell A. Petersen, 2019, Information: Hard and soft, Review of Corporate Finance Studies 8, 1-41.

Lisowsky, Petro, Michael Minnis, and Andrew Sutherland, 2017, Economic growth and financial statement verification, Journal of Accounting Research 55, 745-794.

Maddaloni, Angela, and José-Luis Peydró, 2010, Bank risk-taking, securitization, supervision and low interest rates: Evidence from the euro area and the US lending standards, Technical report, ECB Working Paper.

Meiselman, Ben S., Stefan Nagel, and Amiyatosh Purnanandam, 2020, Judging Banks' Risk by the Profits They Report, Available at SSRN 3169730 .

Mian, Atif, and Amir Sufi, 2009, The consequences of mortgage credit expansion: Evidence from the US mortgage default crisis, The Quarterly Journal of Economics 124, 1449-1496. 
Minsky, Hyman P., and Henry Kaufman, 2008, Stabilizing an Unstable Economy, volume 1 (McGraw-Hill New York).

Morgan, Donald P., Bertrand Rime, and Philip E. Strahan, 2004, Bank integration and state business cycles, The Quarterly Journal of Economics 119, 1555-1584.

Nguyen, Hoai-Luu Q., 2019, Are credit markets still local? Evidence from bank branch closings, American Economic Journal: Applied Economics 11, 1-32.

Ocampo, José Antonio, 2014, The Latin American debt crisis in historical perspective, in Life After Debt, 87-115 (Springer).

Petersen, Mitchell A., and Raghuram G. Rajan, 1994, The benefits of lending relationships: Evidence from small business data, The journal of finance 49, 3-37.

Petersen, Mitchell A., and Raghuram G. Rajan, 2002, Does distance still matter? The information revolution in small business lending, The journal of Finance 57, 2533-2570.

Pflueger, Carolin, Emil Siriwardane, and Adi Sunderam, 2020, Financial market risk perceptions and the macroeconomy, The Quarterly Journal of Economics 135, 1443-1491.

Plosser, Matthew C., and Joao AC Santos, 2018, Banks' incentives and inconsistent risk models, The Review of Financial Studies 31, 2080-2112.

Presbitero, Andrea F., Gregory F. Udell, and Alberto Zazzaro, 2014, The home bias and the credit crunch: A regional perspective, Journal of Money, Credit and Banking 46, 53-85.

Rajan, Raghuram, and Rodney Ramcharan, 2015, The anatomy of a credit crisis: The boom and bust in farm land prices in the United States in the 1920s, American Economic Review 105, $1439-77$.

Rajan, Raghuram G., 1994, Why bank credit policies fluctuate: A theory and some evidence, the Quarterly Journal of economics 109, 399-441.

Ruckes, Martin, 2004, Bank competition and credit standards, Review of financial studies 17, $1073-1102$. 
Stein, Jeremy C., 1989, Efficient capital markets, inefficient firms: A model of myopic corporate behavior, The quarterly journal of economics 104, 655-669.

Stein, Jeremy C., 2002, Information production and capital allocation: Decentralized versus hierarchical firms, The journal of finance 57, 1891-1921.

Stiroh, Kevin J., and Philip E. Strahan, 2003, Competitive dynamics of deregulation: Evidence from US banking, Journal of money, credit and Banking 801-828.

Taylor, John B., 2007, Housing and monetary policy, in Proceedings-Economic Policy SymposiumJackson Hole, 463-476 (Federal Reserve Bank of Kansas City).

Zentefis, Alexander K., 2020, Bank net worth and frustrated monetary policy, Journal of Financial Economics 138, 687-699. 




\section{Figure 2: Evolution of Lending Distances}

Figure 2 shows three plots. Panel A plots the average weighted distance of all small business loans over time. Lending Distance for each loan is computed as the geodetic distance between the borrowers' county centroid and the banks' closest branch. Panel B plots the bank equal-weighted lending distance over time. To compute the bank equal-weighted lending distance, we initially compute the average (volume-weighted) lending distance for each bank-year combination and then average across all banks in each year. Panel $\mathrm{C}$ plots the percentage of loans that are originated to borrowers that are located in counties where the lender does not have a branch. Data for all figures is obtained from the combination of the CRA and SOD datasets.

Panel A: Average Lending Distance (Volume-Weighted)



Panel B: Average Lending Distance (Equal-Weighted across Banks)



Panel C: Proportion of Lending to Counties outside Branch Network (Volume-Weighted)






\section{Figure 3: Evolution of Lending Distances: Other Points of the Distribution}

Figure 3 shows three plots. Panel A plots the median of the weighted distance of all small business loans over time. Lending Distance for each loan is computed as the geodetic distance between the borrowers' county centroid and the banks' closest branch. Panel B plots the lower decile of the weighted distance of all small business loans over time. Lending Distance for each loan is computed as the geodetic distance between the borrowers' county centroid and the banks' closest branch. Panel C plots the upper decile of the weighted distance of all small business loans over time. Lending Distance for each loan is computed as the geodetic distance between the borrowers' county centroid and the banks' closest branch. Data for all figures is obtained from the combination of the CRA and SOD datasets.

Panel A: Median of Lending Distance (Volume-Weighted)

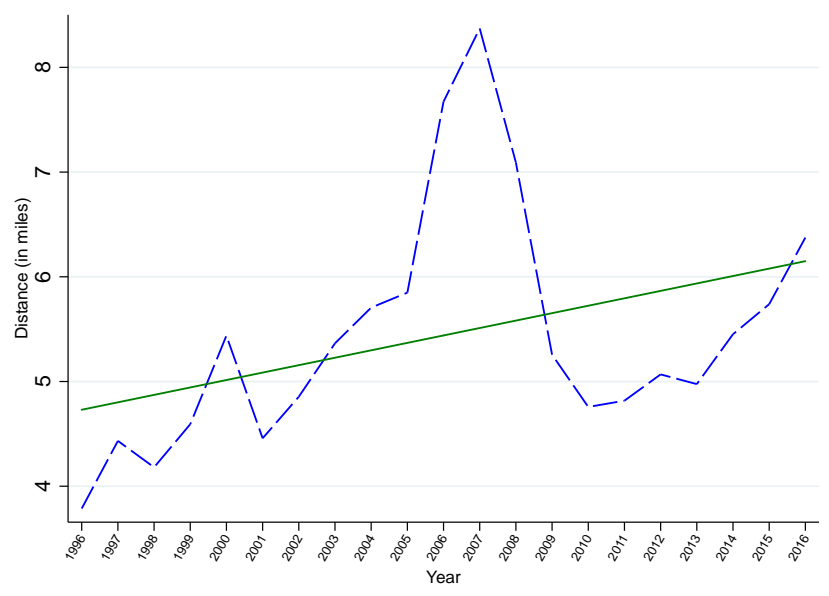

Panel B: Lower Decile of Lending Distance (Volume-Weighted)



Panel C: Upper Decile (Volume-Weighted)






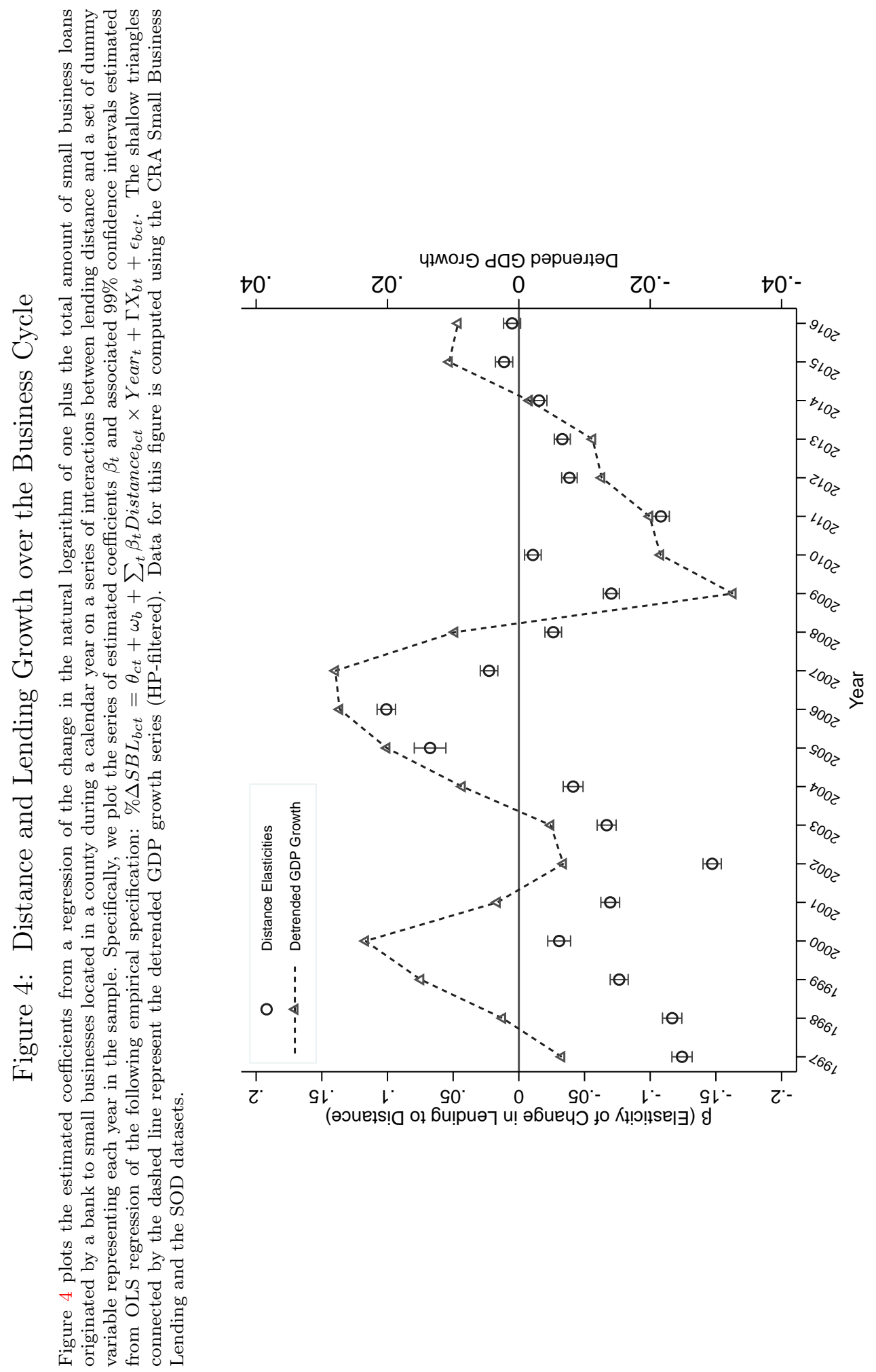








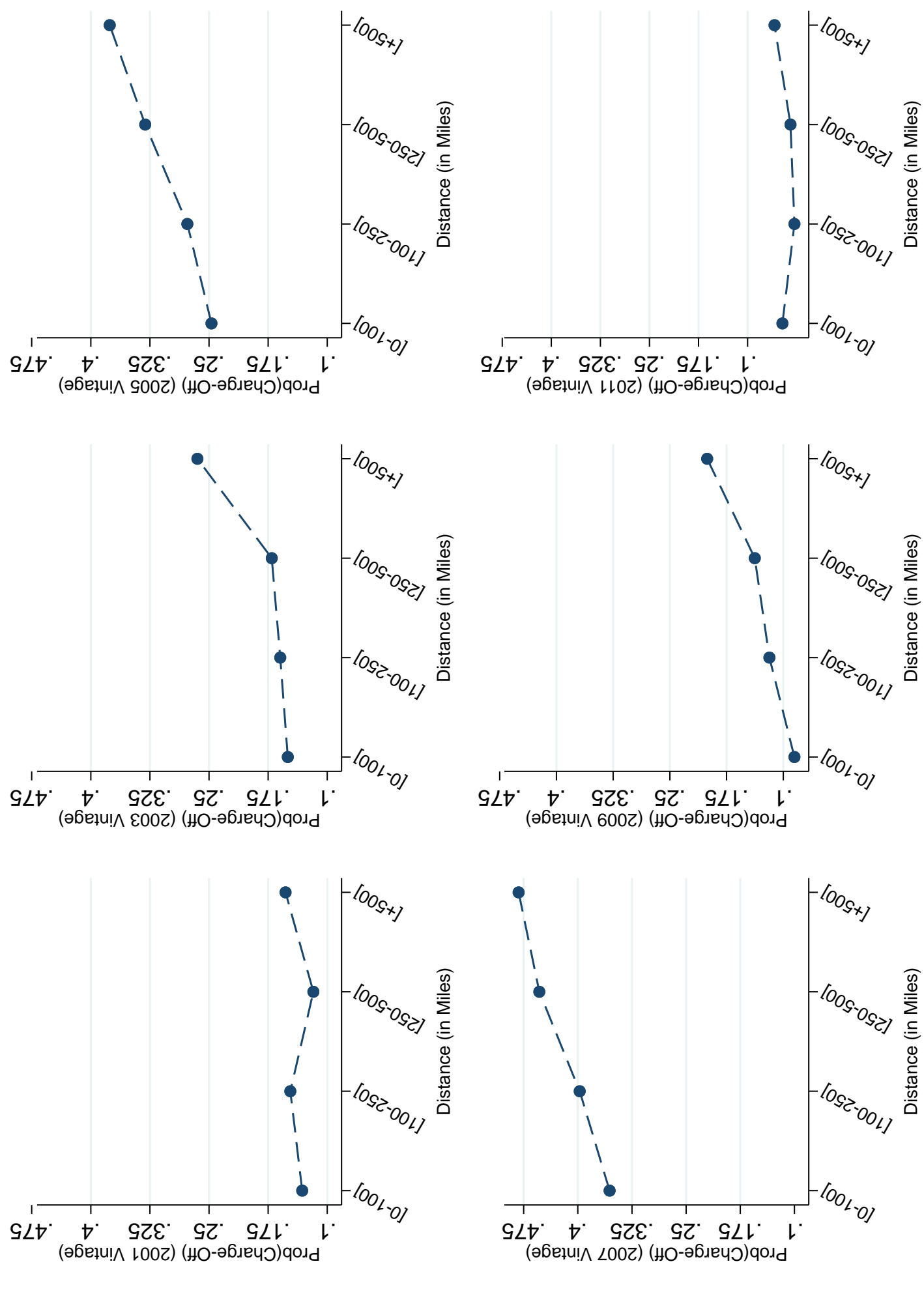












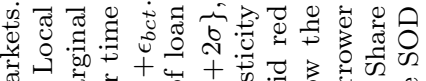
w

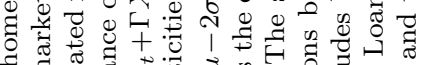

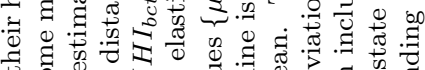

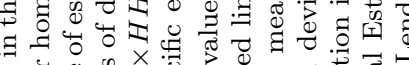

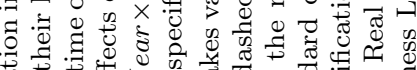

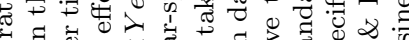

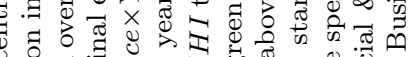



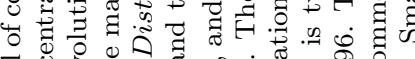
.








४







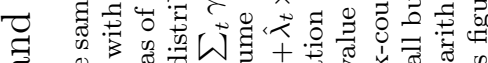





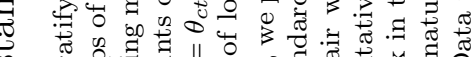
. . D

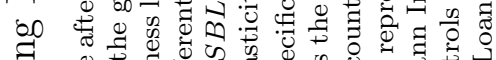
清 $\quad$.

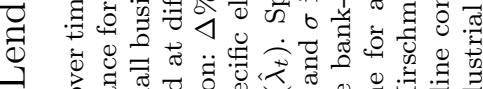
. $\quad 0$ 贾 $\ddot{\sigma}$ 0

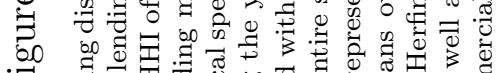

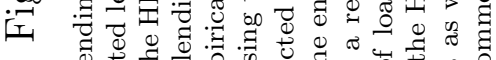
ब

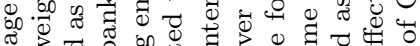

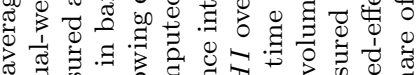

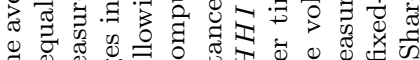

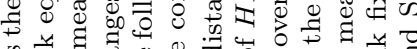

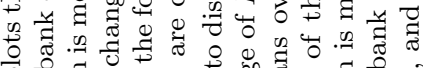
2.

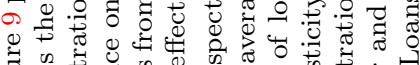

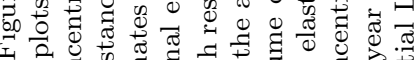

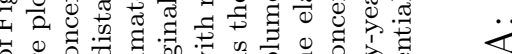

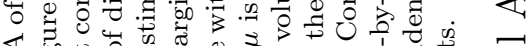

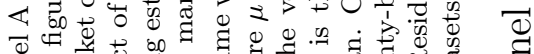

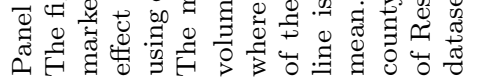

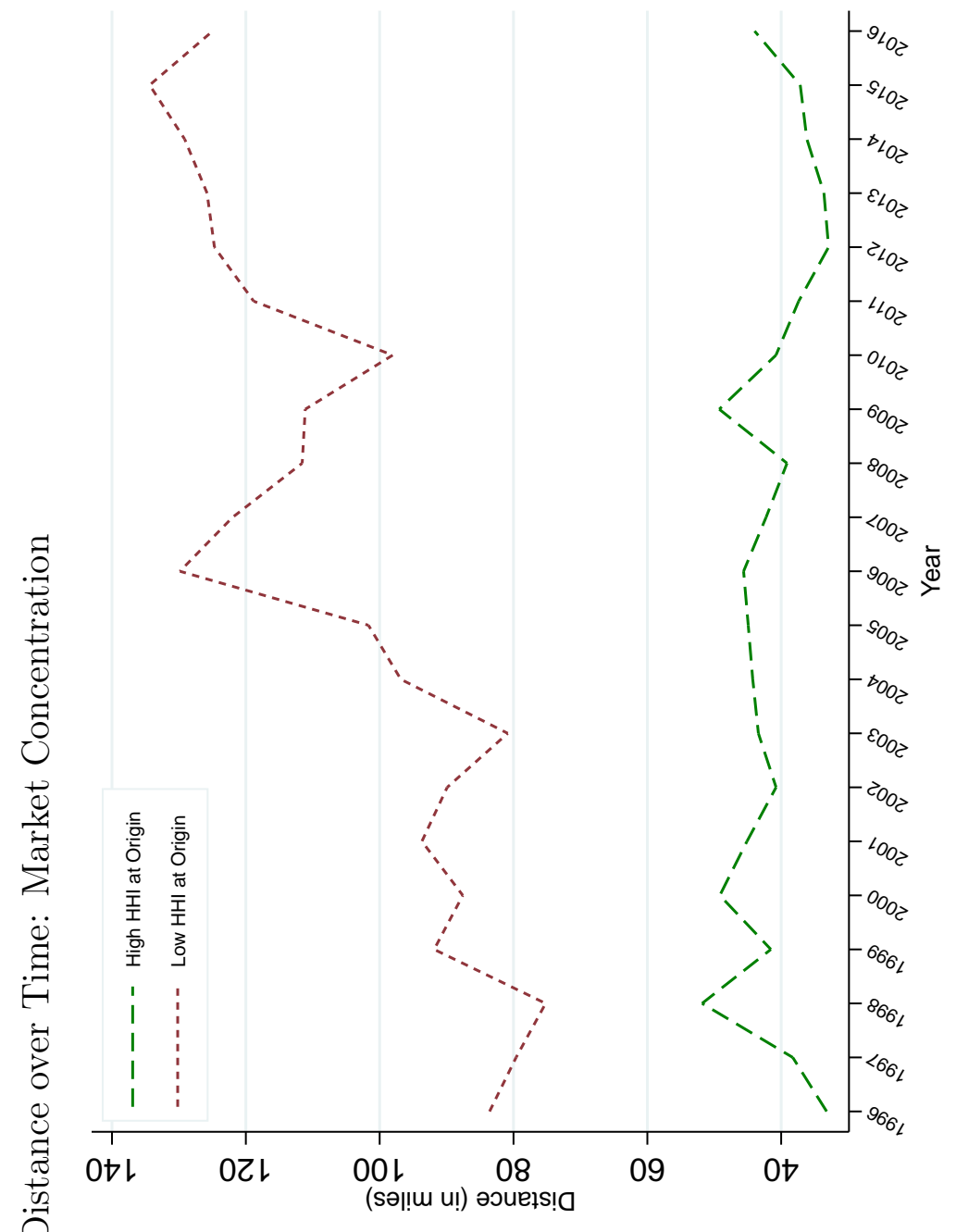




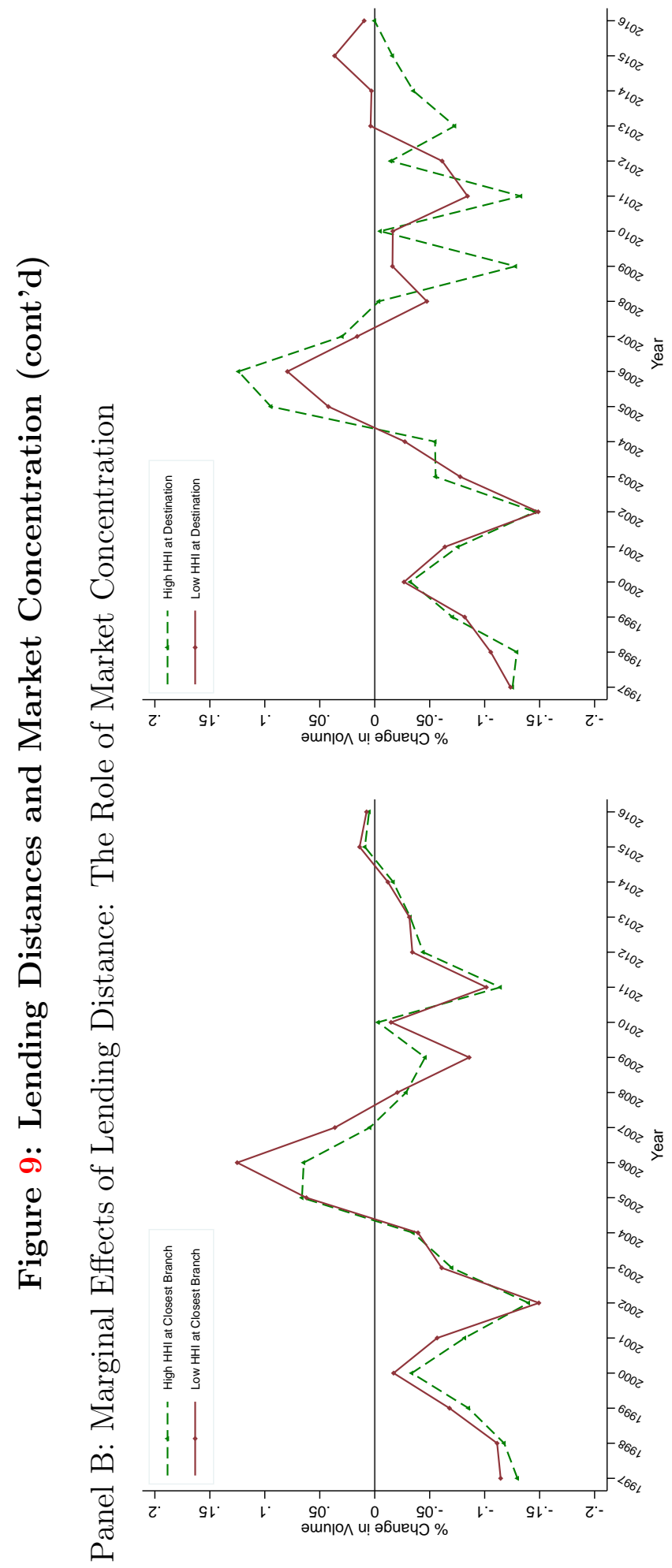




\section{Figure 10: Local Market Concentration and Likelihood of Charge-off in the Small Business}

Administration Loan Dataset

Figure 10 plots the estimated coefficients from a regression of a dummy variable that takes the value of one if loan was charged-off on a series of interactions between the small business lending market concentration in the county where the borrower is located and a set of dummy variable representing each year in the sample. Specifically, we plot the series of estimated coefficients $\beta_{t}$ and associated $99 \%$ confidence intervals estimated from OLS regression of the following empirical specification: $C_{b c t i}=\theta_{t}+\omega_{b}+\theta_{i}+\sum_{t} \beta_{t} H H I_{c} \times Y e a r_{t}+\epsilon_{b c t i}$, where $C O_{b c t i}$ is a dummy variable that takes the value of one if the loan was charged-off and $H H I_{c}$ is the Herfindahl-Hirshmann index (HHI) of the small business lending market in the county where the borrower address is located. We compute the HHI using the same procedure we used in the main sample Data for this figure is computed using the SBA dataset.

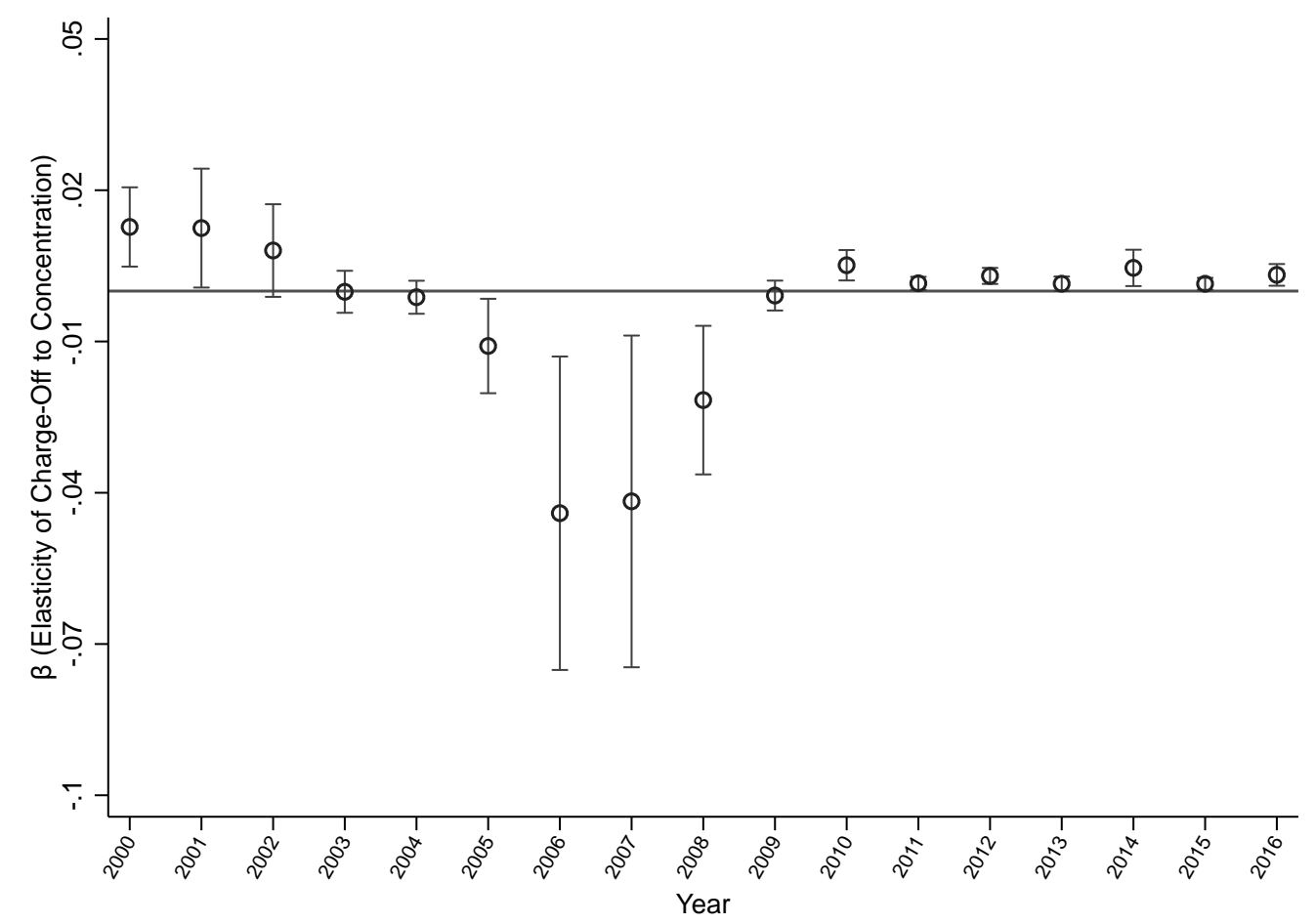




\section{Figure 11: Small Business Lending Flows by County-Pair and Market Concentration}

Figure 11 is a histogram representing frequency of small business lending flows within county-pairs by type of flow (unilateral (only inflow or outflow) or bilateral) and by relative differential in market concentration with each county-pair. All county-pairs with strictly positive small business lending flows are categorized in 3 groups: counties receiving unilateral inflows of small business loans from banks without a branch presence in their county (only inflow county-pairs); counties whose lenders send unilateral flows of small business loans to borrowers located in the other county in the county-pair; and counties with bilateral flows of small business lending. We plot the frequency of county-pairs in each group by the relative concentration differential within each county-pair. Specifically, we compute HHIShare $=\frac{H H I c 1}{H H I c 1+H H I c 2}$, where HHIc1 is the Herfindahl Hirschmann index of the the county $c_{i}=1$ in the county-pair. The figure suggests that when $c_{i}=1$ is relatively more concentrated, i.e. HHIc1 $>0.5$, counties are much more likely to receive unilateral inflows of small business lending. The sample is limited to county pairs with at least one direction of flows being positive. In total there are 106,114 county-pairs in the sample. Pairings of counties with themselves are dropped. Within-county credit volumes are excluded from calculations.

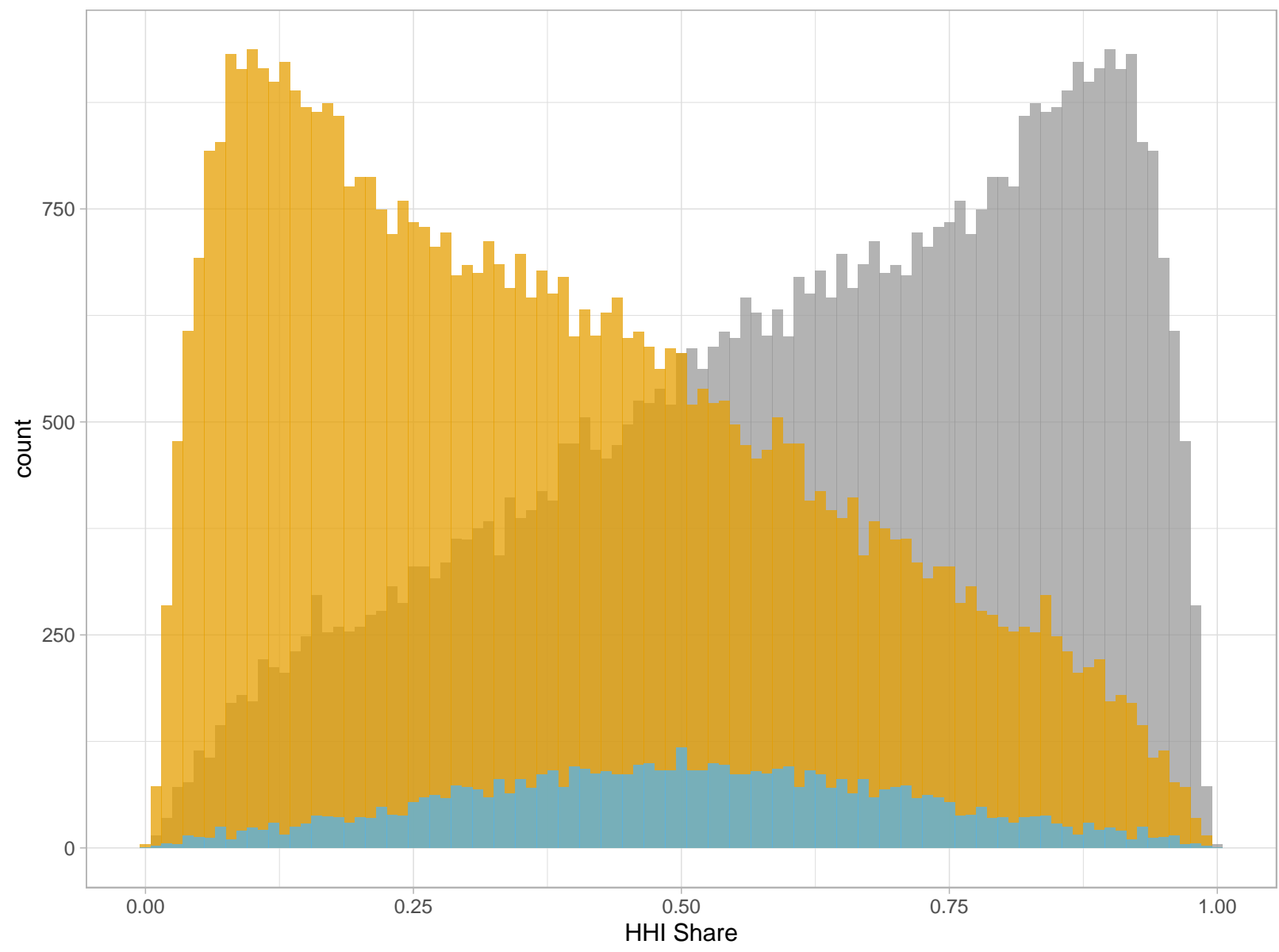

Outflow Group

Only Inflow

Only Outflow

Both Dir 


\section{Figure 12: Deposit Growth Rates (2004-2007) and Deposit Market Concentration}

Figure 12 partitions all counties in ten bins based on their average deposit concentration indices between 1994 and 2013 and plots their respective average annualized deposit growth rate between 2004 and 2007. Data for this figure is from the SOD dataset.

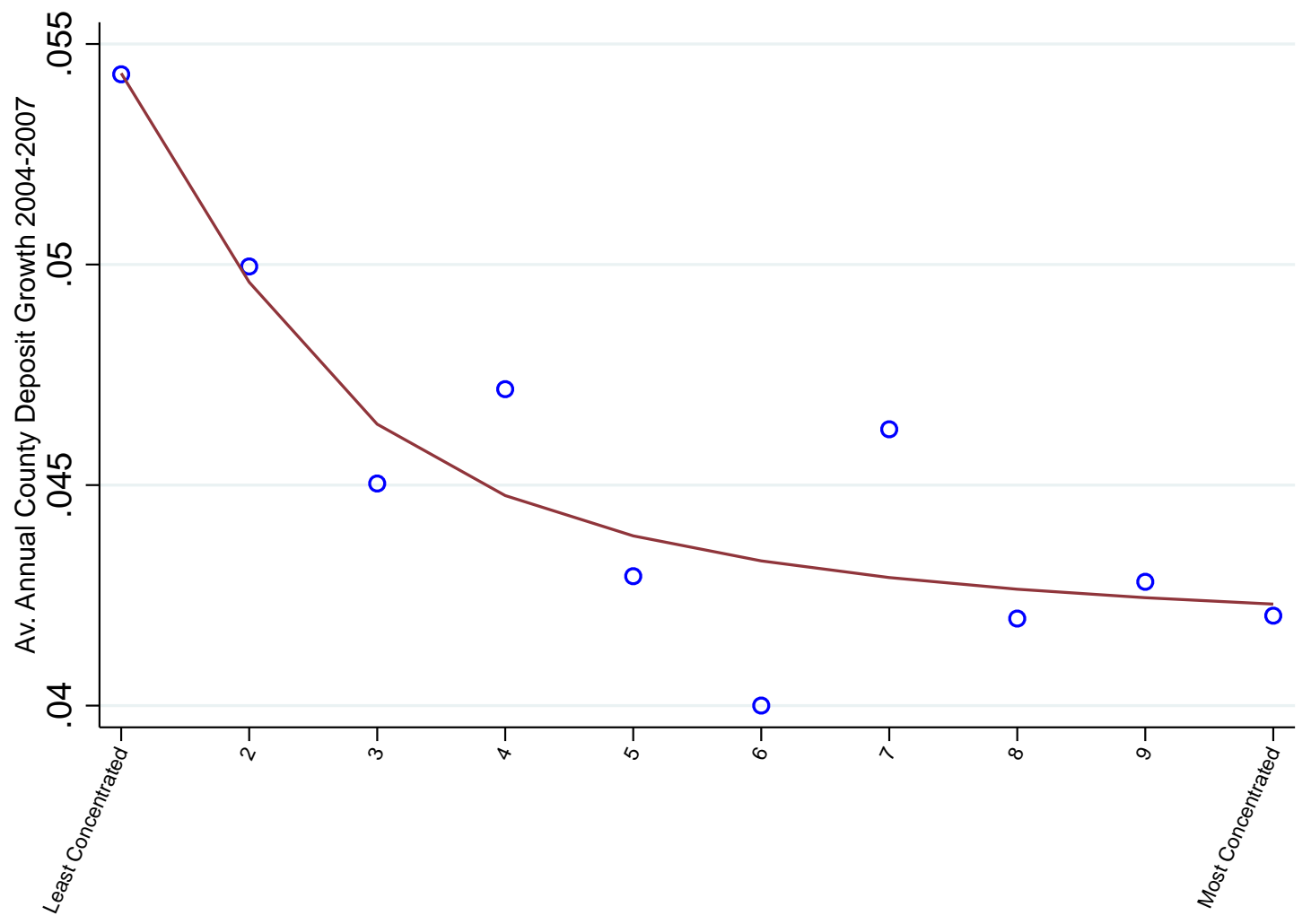


Figure 13: Bank Internal Capital Markets: Coefficient of Variation of HHI within Branch Network

Figure 13 plots the average lending distance over time after stratifying banks based on the coefficient of variation of the market concentration in counties where banks have a branch presence. The plot represents the equal-weighted bank distance for the group of banks with above- and below-median coefficient of variation in market concentration. Local market concentration is measured as the HHI of the small business lending market as of 1996. Data for this figure is computed using the CRA Small Business Lending and the SOD datasets.

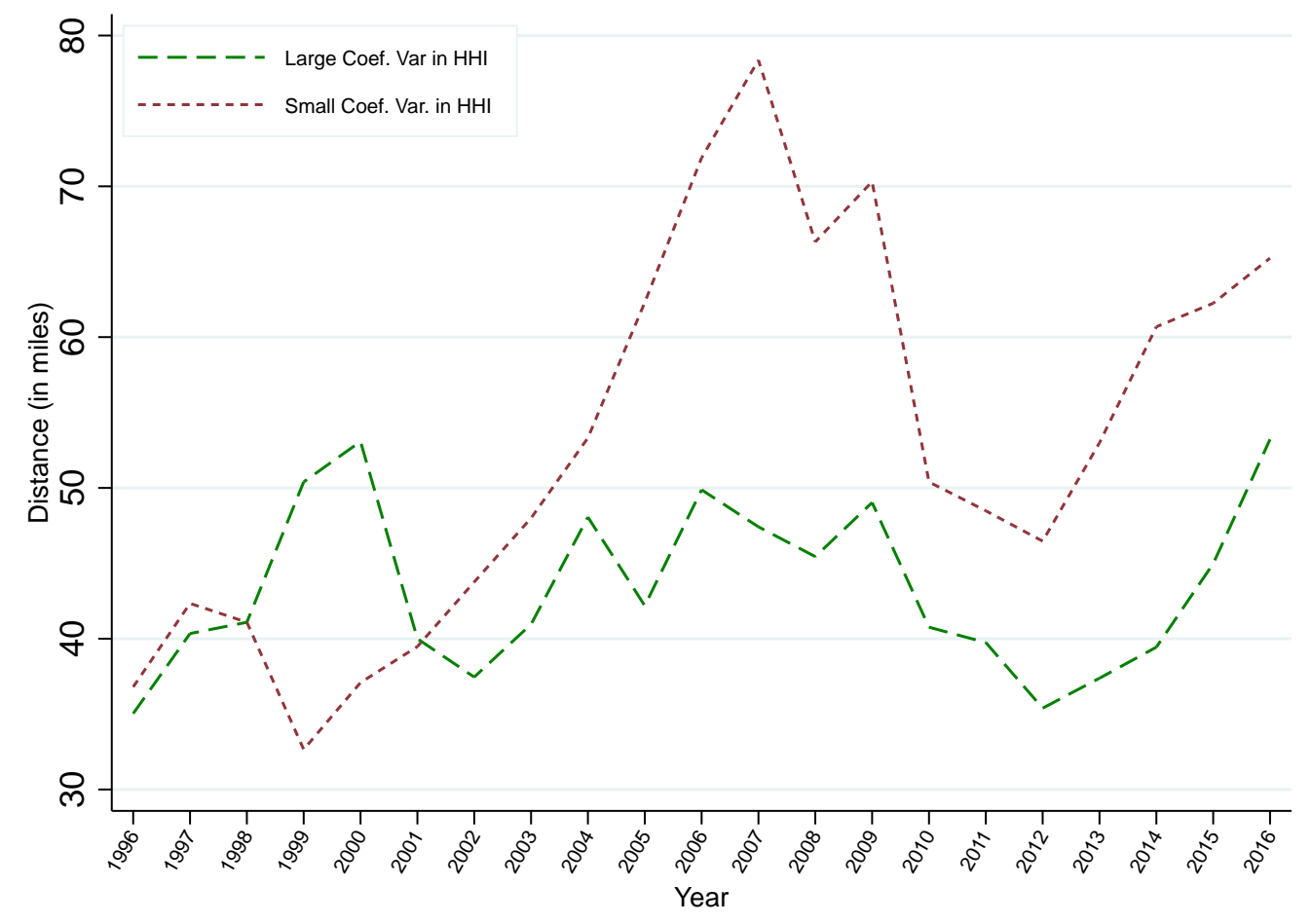




\section{Figure 14: Lending Distances and NonPerforming Loan Ratios}

Figure 14 plots the average lending distance over time after stratifying the sample of banks based on the average nonperforming loan ratio of banks over the 2007-2009 period. The figure plots the equal-weighted bank distance for banks with above-median and below-median nonperforming loan ratio during the 2007-2009 period. Data for this figure is computed using the CRA Small Business Lending and the SOD datasets.

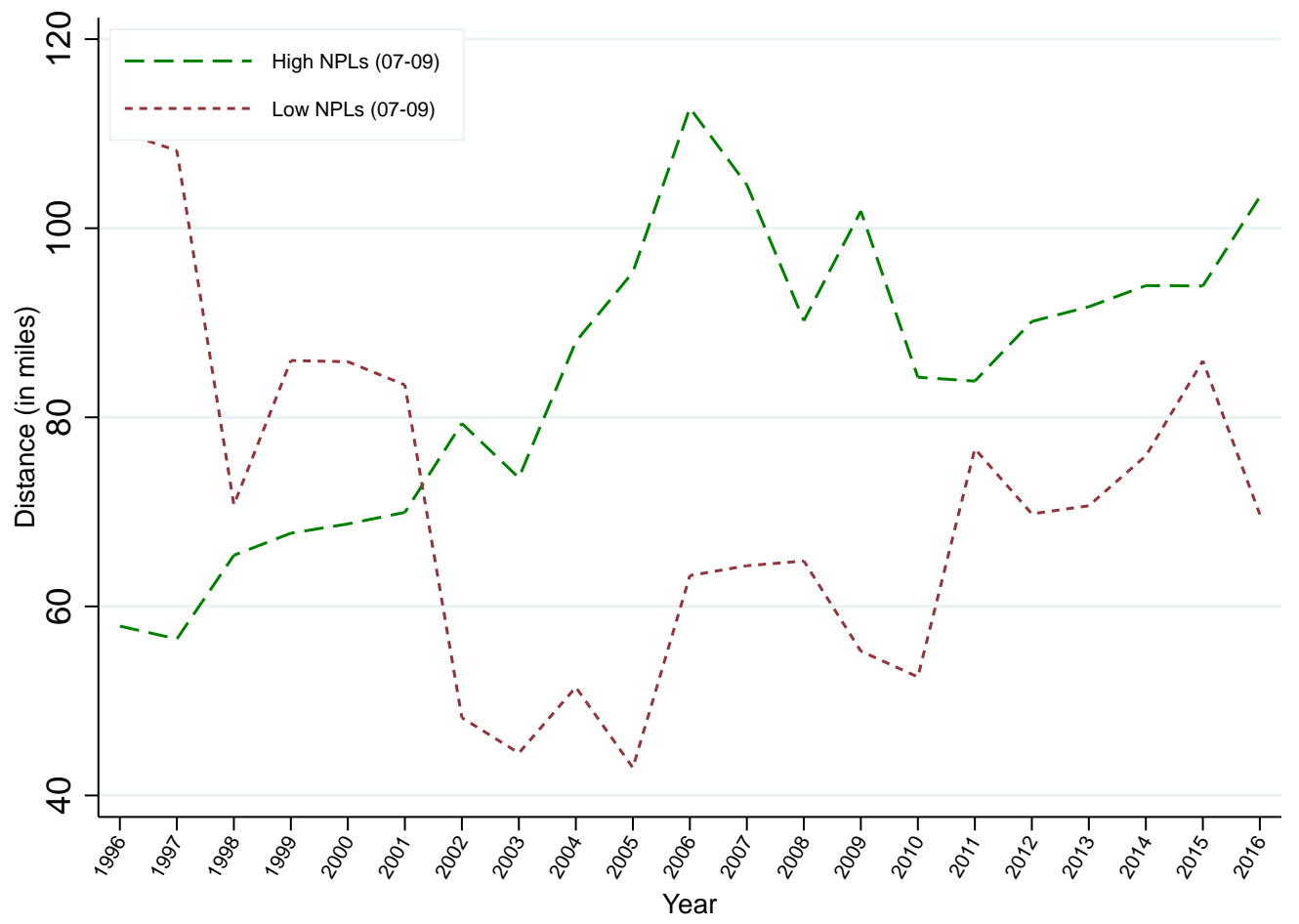


Table 1: Evolution of Total Amounts of Small Business Loans by Distance Category

Panel A of Table 1 reports the total amount of small business loans originations reported in the Community Reinvestment Act (CRA) data by year in each bin representing the distance between the centroid of the borrower's county and the closest branch of the lender. The first bin represents distances between 0 and 50 miles, the second bin represents distances between 50 and 250 miles, the third bin represents distances between 250 and 1,000 miles, and the fourth bin represents borrowers and lenders that are more 1,000 miles apart. Panel B of Table 1 reports the total amount of small business administration (SBA) loans originated in each year in each bin representing the distance between the main address of the borrowerand the closest branch of the lender.

Panel A: Volume of Small Business Loans Originations (CRA Data)

\begin{tabular}{cccccc}
\hline \hline Year & TotalAmount0-50 & TotalAmount50-250 & TotalAmount250-1000 & TotalAmount1000+ & Total \\
\hline 1996 & $102,810,187$ & $4,207,821$ & $3,382,060$ & $4,521,376$ & $114,921,440$ \\
1997 & $130,541,771$ & $9,011,385$ & $7,294,432$ & $3,658,818$ & $150,506,400$ \\
1998 & $134,040,900$ & $7,586,946$ & $5,523,642$ & $5,249,394$ & $152,400,880$ \\
1999 & $142,967,977$ & $9,776,986$ & $7,919,726$ & $7,711,816$ & $168,376,512$ \\
2000 & $137,800,645$ & $7,804,078$ & $10,084,909$ & $15,700,647$ & $171,390,272$ \\
2001 & $182,673,269$ & $8,627,703$ & $12,624,184$ & $13,999,950$ & $217,925,104$ \\
2002 & $204,409,403$ & $11,214,714$ & $16,732,366$ & $15,231,616$ & $247,588,096$ \\
2003 & $219,894,320$ & $13,455,397$ & $18,986,276$ & $16,893,891$ & $269,229,888$ \\
2004 & $228,972,188$ & $16,170,460$ & $21,081,718$ & $18,245,999$ & $284,470,368$ \\
2005 & $207,047,621$ & $11,563,120$ & $25,801,432$ & $21,508,697$ & $265,920,864$ \\
2006 & $211,827,508$ & $14,268,358$ & $33,756,442$ & $38,557,316$ & $298,409,632$ \\
2007 & $220,991,082$ & $18,161,007$ & $40,876,932$ & $44,251,324$ & $324,280,352$ \\
2008 & $201,959,841$ & $14,706,960$ & $31,980,520$ & $34,918,256$ & $283,565,568$ \\
2009 & $151,126,509$ & $10,545,131$ & $15,644,679$ & $12,350,881$ & $189,667,200$ \\
2010 & $125,778,600$ & $5,774,139$ & $11,491,502$ & $10,745,321$ & $153,789,568$ \\
2011 & $156,682,966$ & $7,658,716$ & $12,984,423$ & $13,663,029$ & $190,989,136$ \\
2012 & $159,458,555$ & $8,155,063$ & $14,136,942$ & $15,392,479$ & $197,143,040$ \\
2013 & $166,528,022$ & $9,207,467$ & $12,861,050$ & $14,120,501$ & $202,717,040$ \\
2014 & $164,842,998$ & $9,961,296$ & $14,175,761$ & $17,229,328$ & $206,209,376$ \\
2015 & $171,910,621$ & $10,476,532$ & $17,022,217$ & $18,846,757$ & $218,256,128$ \\
2016 & $173,466,401$ & $11,689,602$ & $20,434,227$ & $21,895,135$ & $227,485,360$ \\
\hline \hline
\end{tabular}

Panel B: Volume of Small Business Administration (SBA) Loans

\begin{tabular}{cccccc}
\hline \hline Year & TotalAmount0-50 & TotalAmount50-250 & TotalAmount250-1000 & TotalAmount1000+ & Total \\
\hline 2000 & $3,633,314$ & $1,466,684$ & $1,512,078$ & $1,218,696$ & $7,830,772$ \\
2001 & $4,348,972$ & $1,482,019$ & $1,494,748$ & 758,103 & $8,083,842$ \\
2002 & $5,543,095$ & $1,847,157$ & $1,410,184$ & 818,440 & $9,618,876$ \\
2003 & $6,229,700$ & $1,814,495$ & $1,432,844$ & 620,479 & $10,097,518$ \\
2004 & $7,305,278$ & $2,051,545$ & $1,707,656$ & 701,895 & $11,766,374$ \\
2005 & $8,384,658$ & $2,287,541$ & $1,633,246$ & 698,314 & $13,003,759$ \\
2006 & $7,931,796$ & $2,007,424$ & $1,771,869$ & 725,878 & $12,436,969$ \\
2007 & $7,635,504$ & $1,784,334$ & $2,071,926$ & 764,074 & $12,255,839$ \\
2008 & $6,365,222$ & $1,300,046$ & $1,529,026$ & 723,373 & $9,917,666$ \\
2009 & $7,203,718$ & $1,446,433$ & $1,105,832$ & 552,657 & $10,308,640$ \\
2010 & $12,114,943$ & $2,045,745$ & $1,645,449$ & 773,776 & $16,579,913$ \\
2011 & $10,351,332$ & $1,423,625$ & $1,049,662$ & 519,079 & $13,343,698$ \\
2012 & $11,202,360$ & $1,707,601$ & $1,479,282$ & 791,290 & $15,180,532$ \\
2013 & $12,148,418$ & $1,986,845$ & $1,778,846$ & 926,175 & $16,840,286$ \\
2014 & $13,429,151$ & $2,176,809$ & $2,284,627$ & $1,294,142$ & $19,184,728$ \\
2015 & $15,269,572$ & $2,347,196$ & $3,055,948$ & $1,865,911$ & $22,538,628$ \\
2016 & $15,273,487$ & $2,553,234$ & $3,515,459$ & $1,916,885$ & $23,259,064$ \\
\hline \hline
\end{tabular}




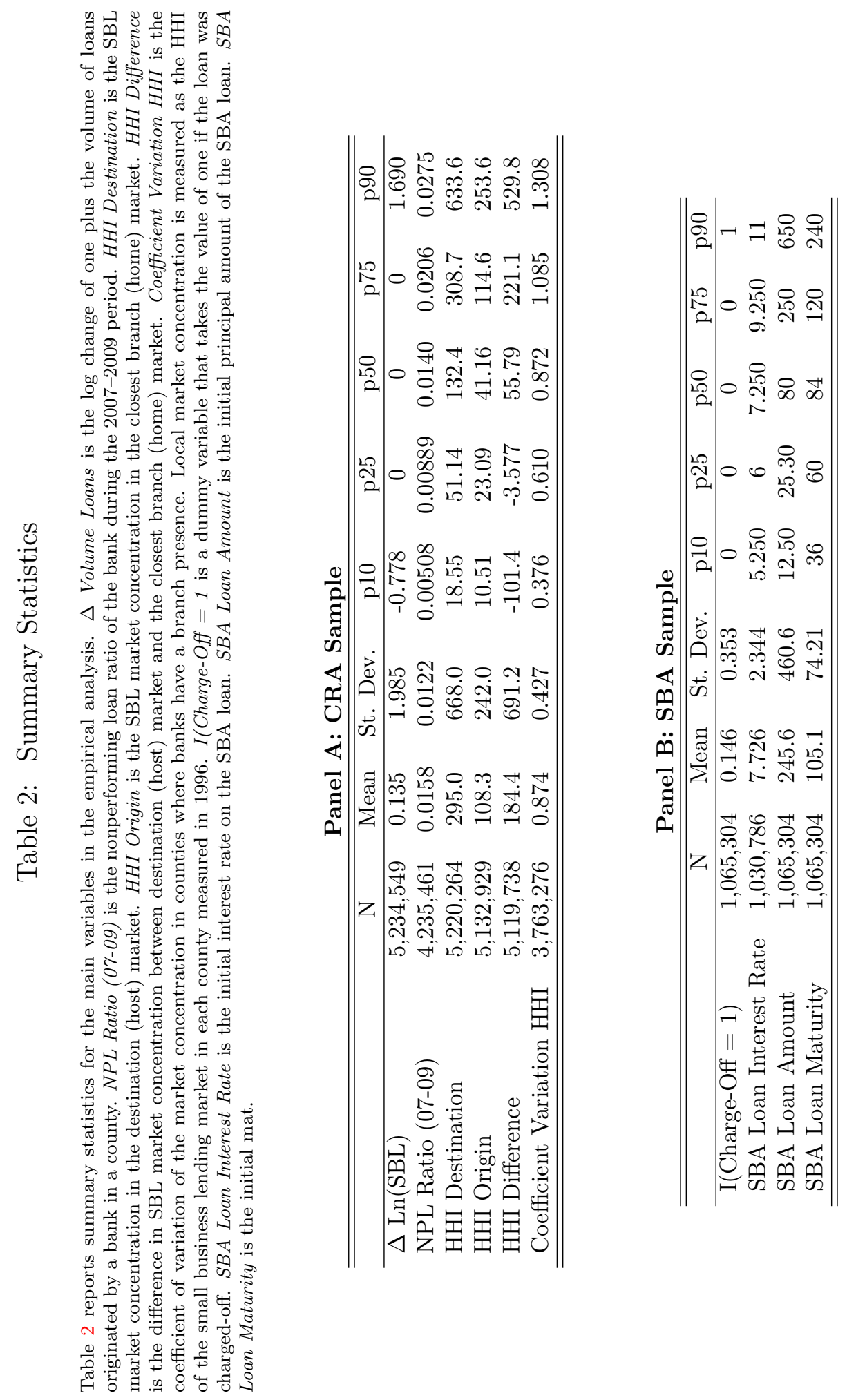




\section{Table 3: Distance and Small Business Lending: Business Cycle Indicators}

Table 4 reports the coefficients of OLS regressions investigating the effect of distance on small business loan originations. $\Delta$ Volume Loans is the log change of one plus the volume of loans originated by a bank in a county. HP-Filtered Real GDP is the standardized HP-filtered percent change in the real GDP. Real GDP series is obtained from the Federal Reserve Economic Data (FRED) website of the Federal Reserve of St. Louis. $\Delta$ Ln (Unempld Rate) is standardized log difference in the US annual unemployment rate. The unemployment rate series is obtained from the Federal Reserve Economic Data (FRED) website of the Federal Reserve of St. Louis. Spreads is the standardized net percentage of domestic banks increasing spreads of loan rates over banks' cost of funds to small firms. The series is obtained from the Federal Reserve Economic Data (FRED) website of the Federal Reserve of St. Louis. Ln(Distance) is the natural logarithm of the minimum distance between the bank's branches and the county centroid. The specification includes borrower county-by-year and bank fixed-effects as well as baseline controls for natural logarithm of Total Assets, Share of Commercial \& Real Estate Loans, Share of Residential Loans, and Share of Commercial \& Industrial Loans. Standard errors are presented in parentheses, and are clustered at the level of the county. ${ }^{* * *},{ }^{* *}$, and ${ }^{*}$, represent statistical significance at $1 \%, 5 \%$, and $10 \%$ levels, respectively.

\begin{tabular}{|c|c|c|c|}
\hline & (1) & $(2)$ & (3) \\
\hline & \multicolumn{3}{|c|}{$\Delta$ Volume Loans } \\
\hline Ln(Distance) & $\begin{array}{l}-0.038^{* * *} \\
(0.001)\end{array}$ & $\begin{array}{l}-0.038^{* * *} \\
(0.001)\end{array}$ & $\begin{array}{l}-0.038^{* * *} \\
(0.001)\end{array}$ \\
\hline Ln $($ Distance $) \times$ HP-Filtered Real GDP & $\begin{array}{l}0.035^{* * *} \\
(0.001)\end{array}$ & & \\
\hline $\operatorname{Ln}($ Distance $) \times \Delta \operatorname{Ln}($ Unempld Rate $)$ & & $\begin{array}{l}-0.018^{* * *} \\
(0.000)\end{array}$ & \\
\hline $\operatorname{Ln}($ Distance $) \times$ Spreads & & & $\begin{array}{l}-0.017^{\text {*** }} \\
(0.000)\end{array}$ \\
\hline Observations & 5234549 & 5234549 & 5234549 \\
\hline Adjusted $R^{2}$ & 0.017 & 0.017 & 0.017 \\
\hline Baseline Controls & Yes & Yes & Yes \\
\hline Bank Fixed Effects & Yes & Yes & Yes \\
\hline Borrower County-Year Fixed Effects & Yes & Yes & Yes \\
\hline
\end{tabular}




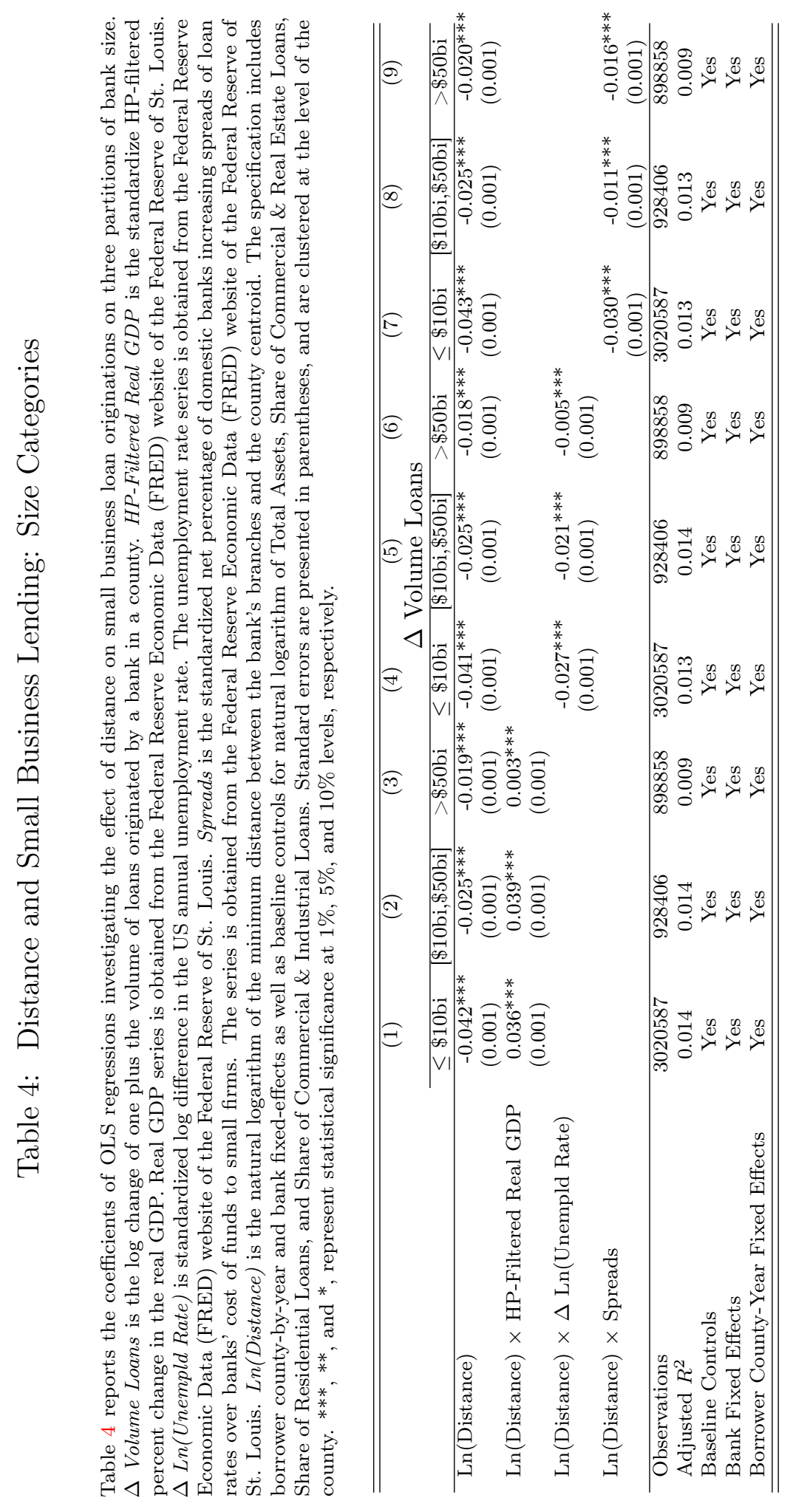




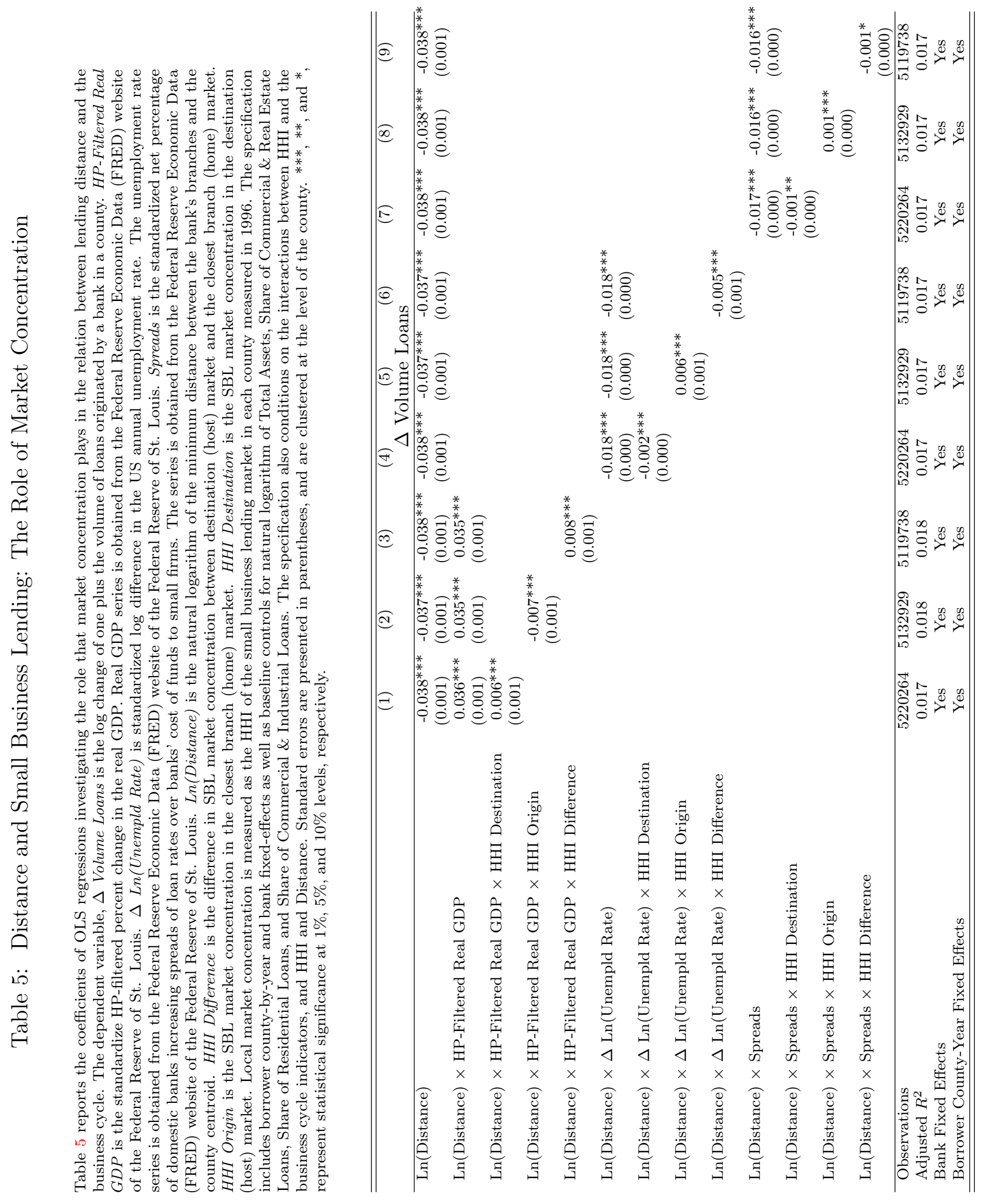




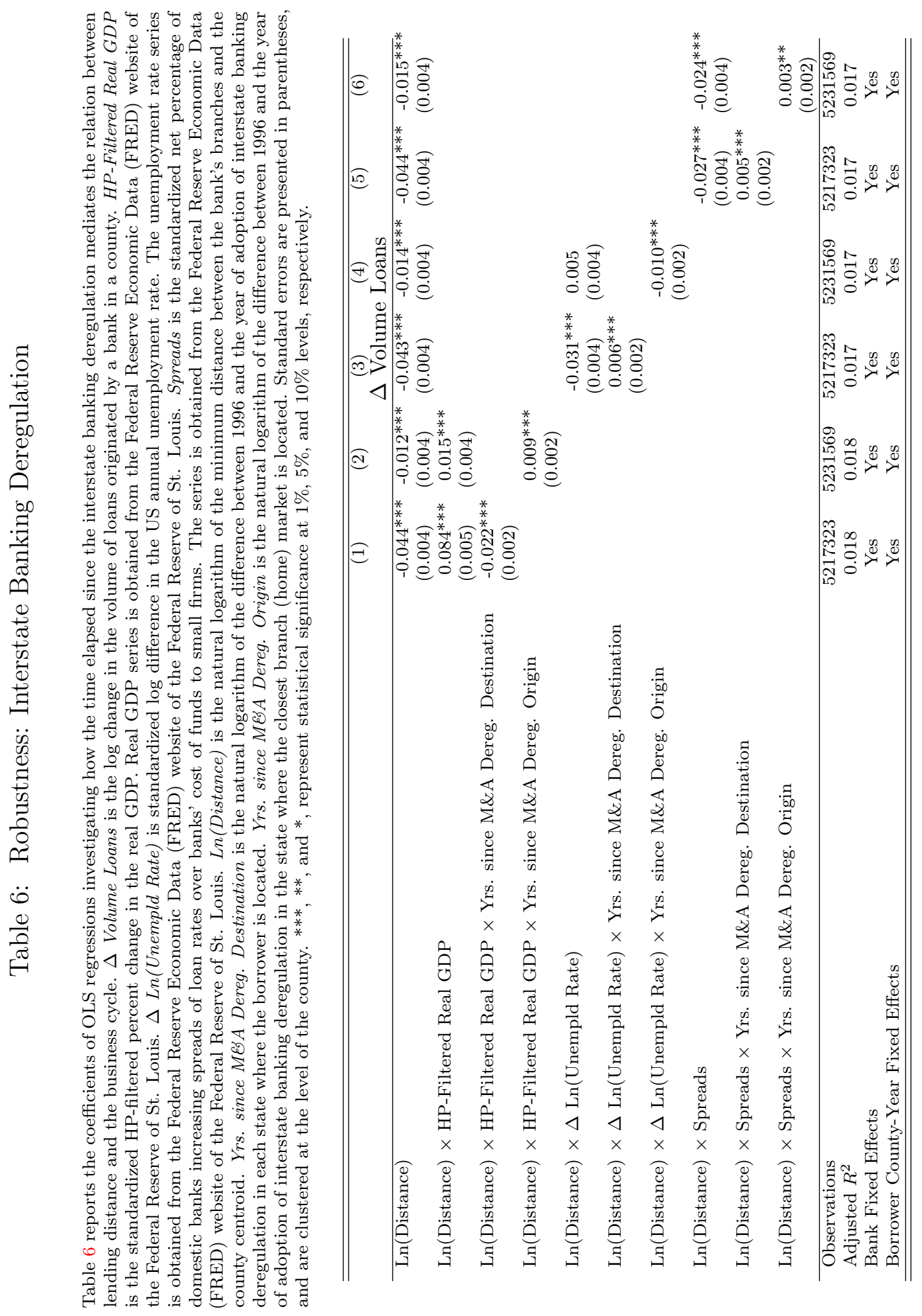




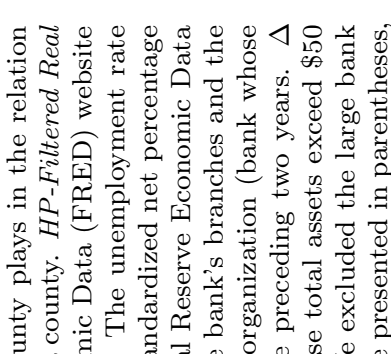

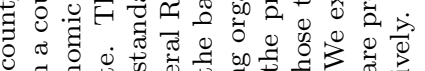

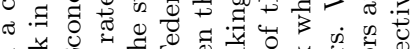
: สี

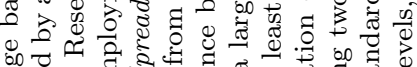

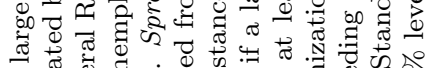

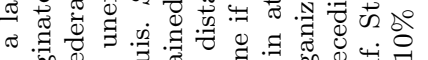

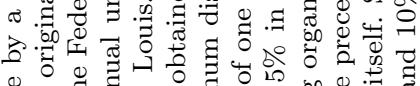

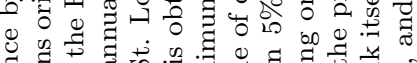

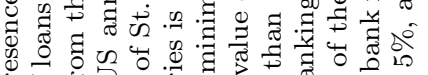

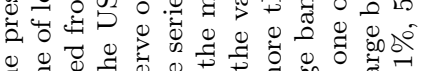

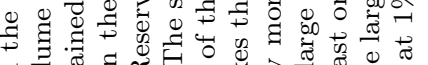

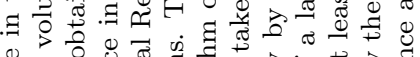





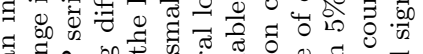

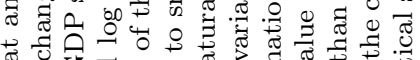

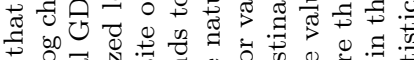



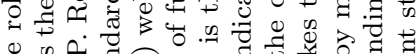

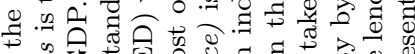

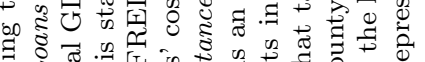

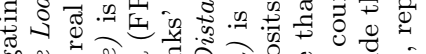



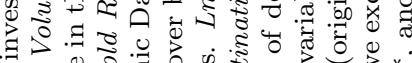

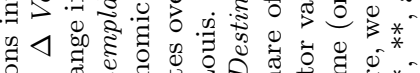

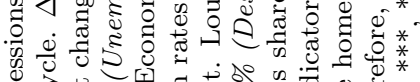

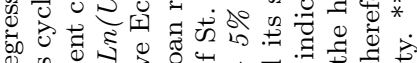



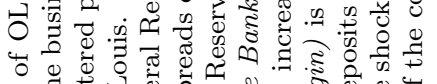

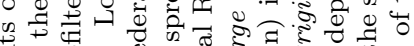

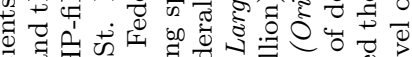

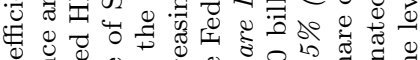

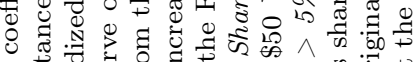

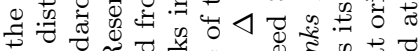
क

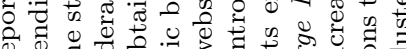
Q 人.

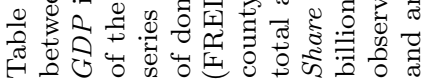

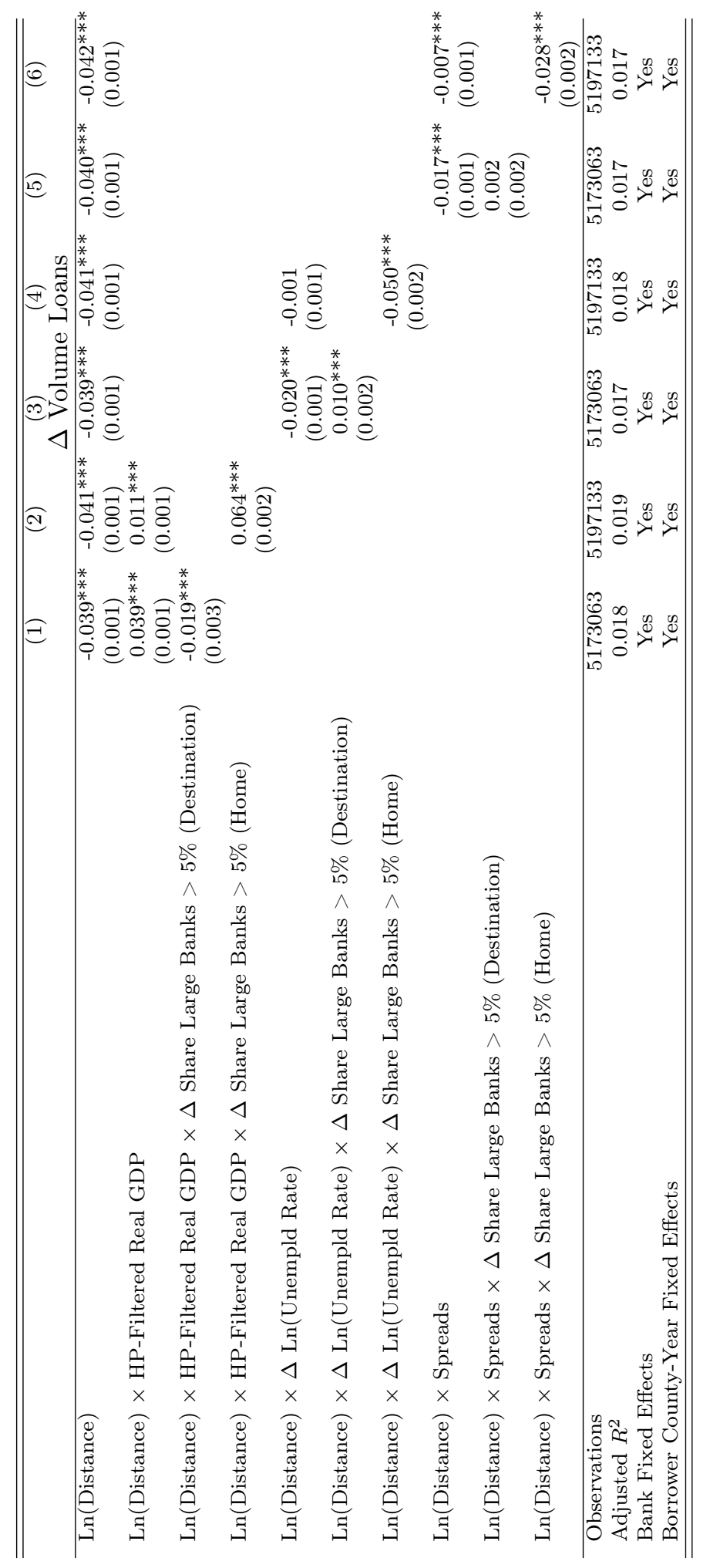




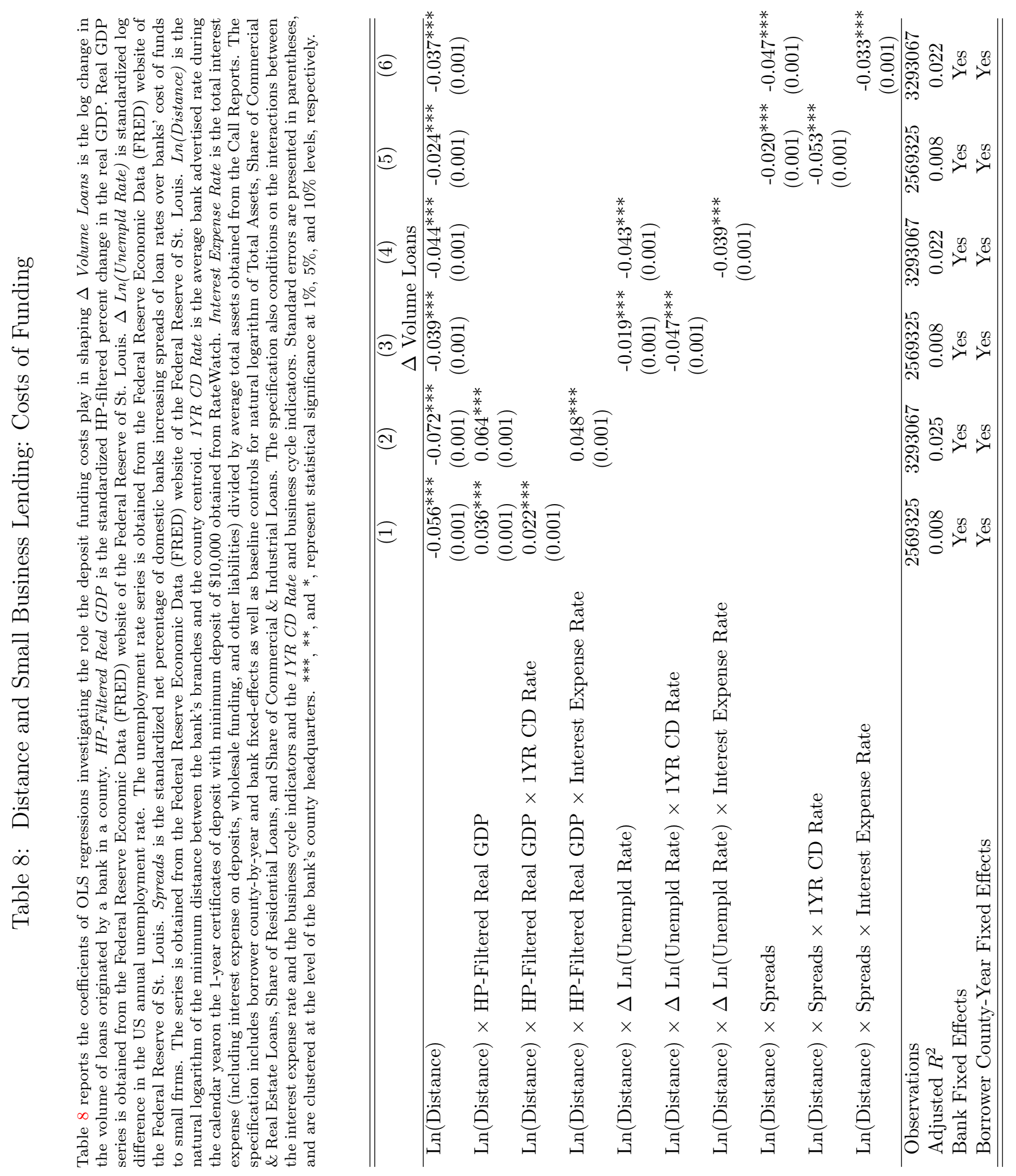




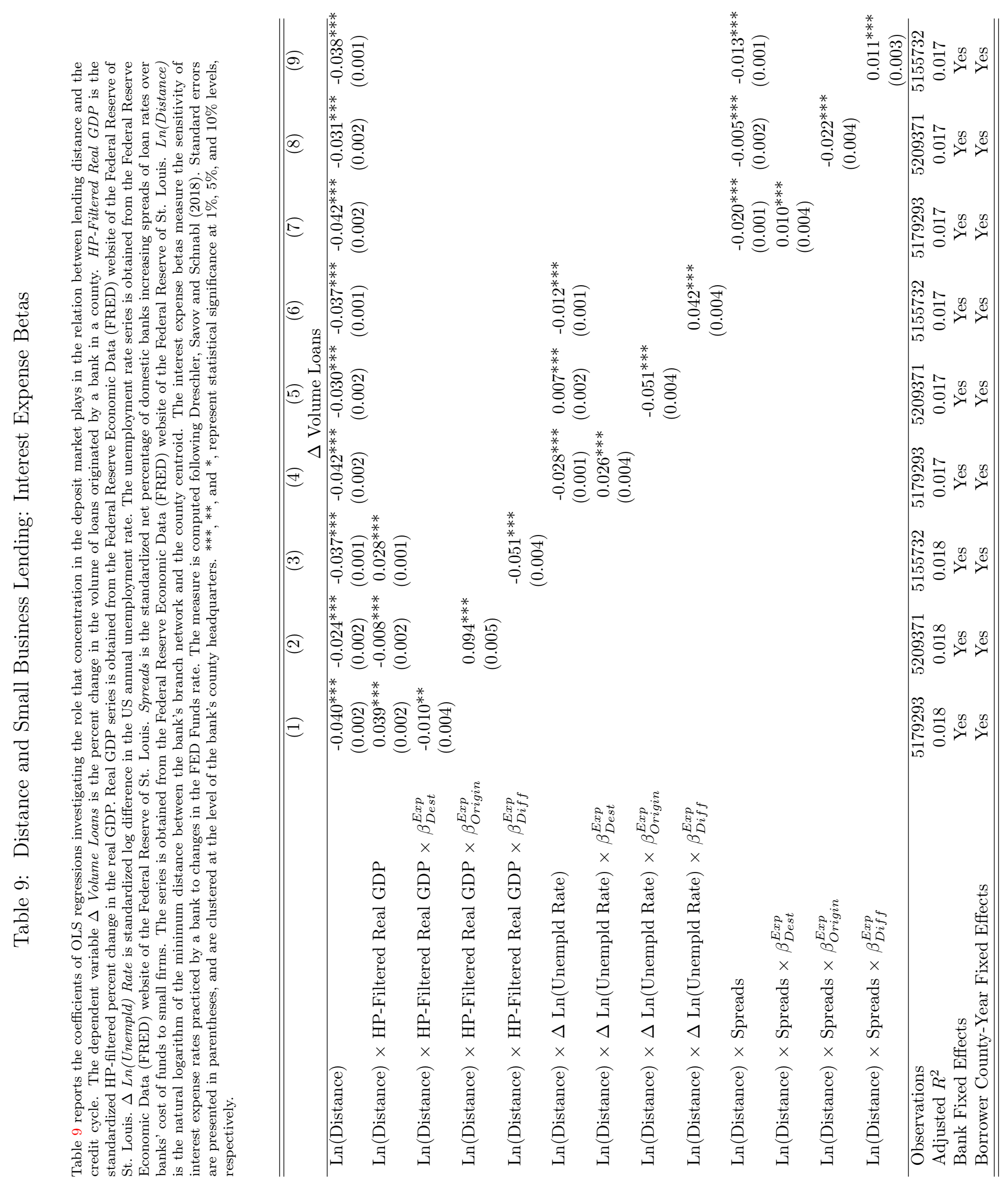



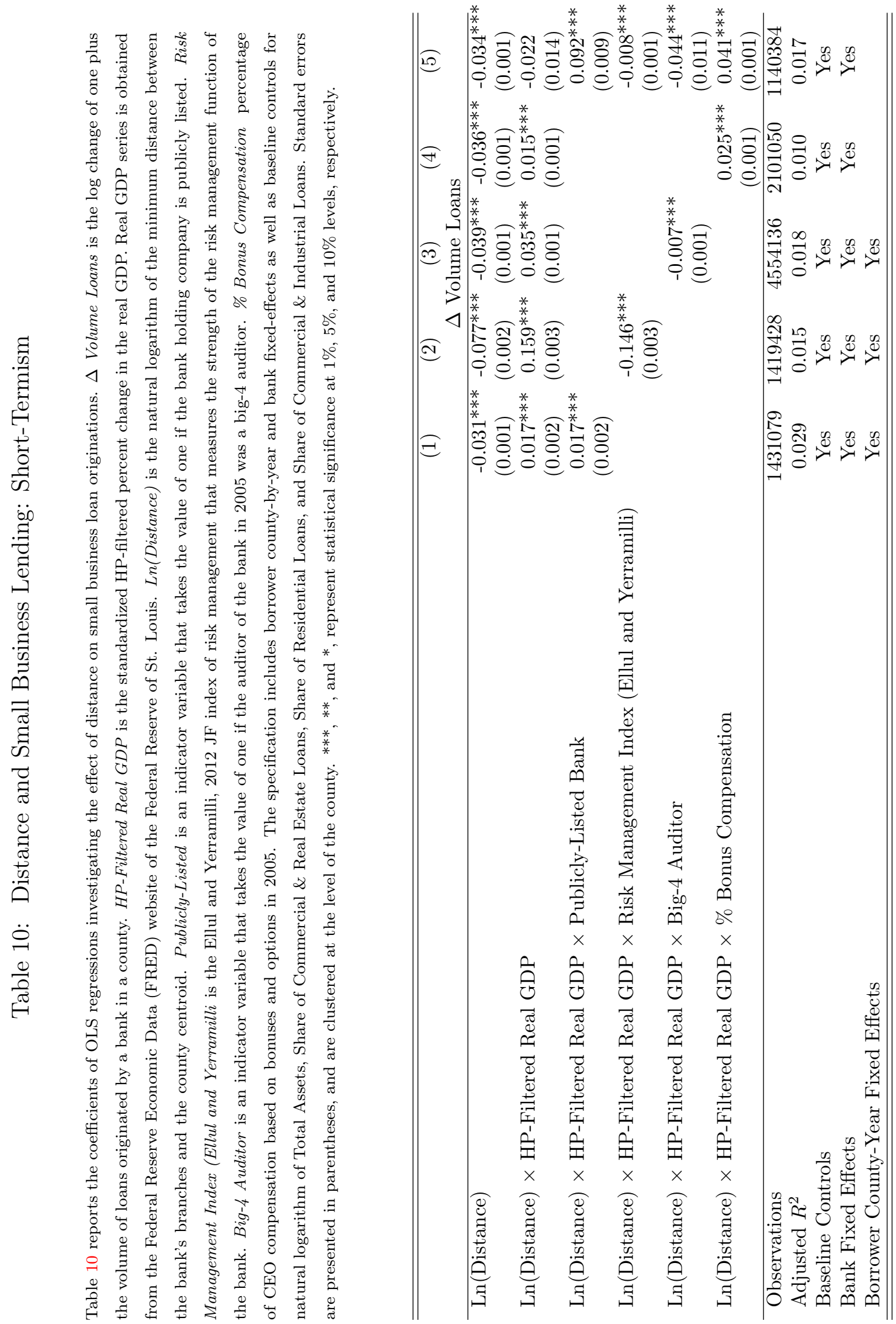

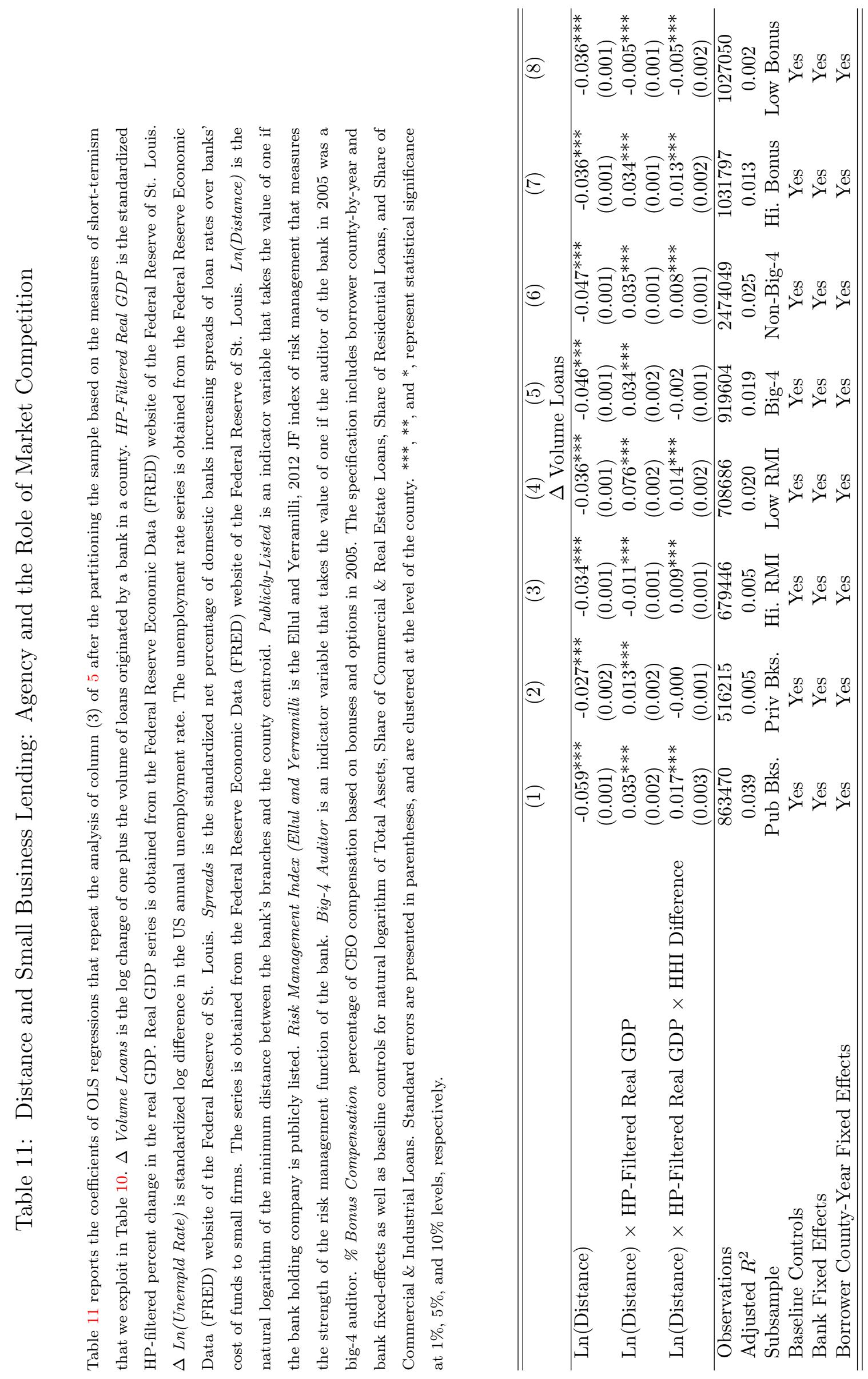


\section{Table 12: Distance and Small Business Lending: The Role of Internal Capital Markets}

Table 12 reports the coefficients of OLS regressions investigating the role that internal capital markets play in the relation between lending distance and the business cycle. The dependent variable, $\Delta$ Volume Loans, is the log change in the volume of loans originated by a bank in a county. HP-Filtered Real GDP is the standardize HP-filtered percent change in the real GDP. Real GDP series is obtained from the Federal Reserve Economic Data (FRED) website of the Federal Reserve of St. Louis. $\Delta$ Ln(Unempld Rate) is standardized log difference in the US annual unemployment rate. The unemployment rate series is obtained from the Federal Reserve Economic Data (FRED) website of the Federal Reserve of St. Louis. Spreads is the standardized net percentage of domestic banks increasing spreads of loan rates over banks' cost of funds to small firms. The series is obtained from the Federal Reserve Economic Data (FRED) website of the Federal Reserve of St. Louis. Ln(Distance) is the natural logarithm of the minimum distance between the bank's branches and the county centroid. Coefficient Variation HHI is the coefficient of variation of the market concentration in counties where banks have a branch presence. Local market concentration is measured as the HHI of the small business lending market as of 1996. The specification includes borrower county-by-year and bank fixed-effects as well as baseline controls for natural logarithm of Total Assets, Share of Commercial \& Real Estate Loans, Share of Residential Loans, and Share of Commercial \& Industrial Loans. The specification also conditions on the interactions between Std. Dev. HHI and the business cycle indicators, and Std. Dev. HHI and Distance. Standard errors are presented in parentheses, and are clustered at the level of the county. ${ }^{* *}, * *$, and $*$, represent statistical significance at $1 \%, 5 \%$, and $10 \%$ levels, respectively.

\begin{tabular}{|c|c|c|c|}
\hline & $(1)$ & $(2)$ & (3) \\
\hline & \multicolumn{3}{|c|}{$\Delta$ Volume Loans } \\
\hline Ln(Distance) & $\begin{array}{l}-0.042^{* * *} \\
(0.001)\end{array}$ & $\begin{array}{l}-0.041^{* * *} \\
(0.001)\end{array}$ & $\begin{array}{l}-0.041^{* * *} \\
(0.001)\end{array}$ \\
\hline Ln(Distance $) \times$ HP-Filtered Real GDP & $\begin{array}{l}0.018^{* * *} \\
(0.001)\end{array}$ & & \\
\hline Ln $($ Distance $) \times$ HP-Filtered Real GDP $\times$ Coefficient Variation HHI & $\begin{array}{l}-0.026^{* * *} \\
(0.001)\end{array}$ & & \\
\hline $\operatorname{Ln}($ Distance $) \times \Delta \operatorname{Ln}($ Unempld Rate $)$ & & $\begin{array}{l}-0.005^{* * *} \\
(0.001)\end{array}$ & \\
\hline $\operatorname{Ln}($ Distance $) \times \Delta \operatorname{Ln}($ Unempld Rate $) \times$ Coefficient Variation HHI & & $\begin{array}{l}0.026^{* * *} \\
(0.001)\end{array}$ & \\
\hline Ln $($ Distance $) \times$ Spreads & & & $\begin{array}{l}-0.015^{* * *} \\
(0.001)\end{array}$ \\
\hline Ln $($ Distance $) \times$ Spreads $\times$ Coefficient Variation HHI & & & $\begin{array}{l}0.025^{* * *} \\
(0.001) \\
\end{array}$ \\
\hline Observations & 3763276 & 3763276 & 3763276 \\
\hline Adjusted $R^{2}$ & 0.019 & 0.019 & 0.019 \\
\hline Baseline Controls & Yes & Yes & Yes \\
\hline Bank Fixed Effects & Yes & Yes & Yes \\
\hline Borrower County-Year Fixed Effects & Yes & Yes & Yes \\
\hline
\end{tabular}




\section{Table 13: Distance and Small Business Lending: NonPerforming Loan Ratio}

Table 13 reports the coefficients of OLS regressions investigating whether the relation between lending distance and the business cycle is more or less pronounced for lenders that experienced greater loan delinquency ratios during the financial crisis (07-09). $\Delta$ Volume Loans is the log change of one plus the volume of loans originated by a bank in a county. HP-Filtered Real GDP is the standardize HP-filtered percent change in the real GDP. Real GDP series is obtained from the Federal Reserve Economic Data (FRED) website of the Federal Reserve of St. Louis. $\Delta$ Ln (Unempld Rate) is standardized log difference in the US annual unemployment rate. The unemployment rate series is obtained from the Federal Reserve Economic Data (FRED) website of the Federal Reserve of St. Louis. Spreads is the standardized net percentage of domestic banks increasing spreads of loan rates over banks' cost of funds to small firms. The series is obtained from the Federal Reserve Economic Data (FRED) website of the Federal Reserve of St. Louis. Ln(Distance) is the natural logarithm of the minimum distance between the bank's branches and the county centroid. NPL Ratio (07-09) is the nonperforming loan ratio of the bank during the 2007-2009 period. The specification includes borrower county-by-year and bank fixed-effects as well as baseline controls for natural logarithm of Total Assets, Share of Commercial \& Real Estate Loans, Share of Residential Loans, and Share of Commercial \& Industrial Loans. The specification also conditions on the interactions between NPL Ratio and the business cycle indicators, and NPL Ratio and Distance. Standard errors are presented in parentheses, and are clustered at the level of the county. $* * *$, $* *$, and $*$, represent statistical significance at $1 \%, 5 \%$, and $10 \%$ levels, respectively.

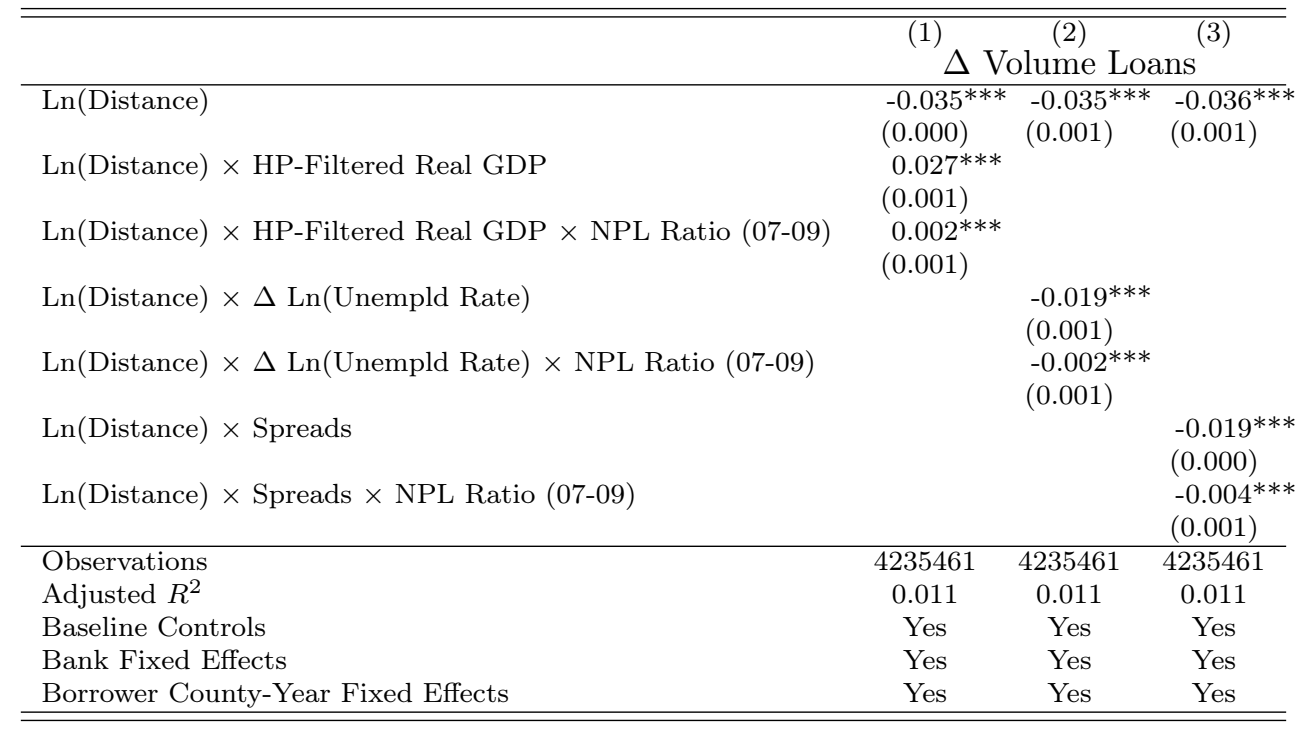


Table 14: Bank Level Analysis: Tail Risks and Distance Cyclicality

Panel A of Table 14 reports summary statistics of the main variables used in the bank-level analysis of distance cyclicality and stock-return based measures of tail risks. Panel B reports the coefficients of OLS regressions investigating the relation between distance cyclicality and tail risks. The dependent variables, Return Bad Bank Days and Return Bad Market Days, are the average bad-day returns of each bank calculated from bad days between September 1, 2007, and October 1, 2010. Bad Bank days are $5 \%$ of days from July 1926 to July 2015 with the lowest value-weighted return for the Fama/French banking industry portfolio and Bad Market days are 5\% of days from July 1926 to July 2015 with the lowest CRSP value-weighted market index return (NYSE, AMEX, NASDAQ \& ARCA). $\rho(G D P, D i s t)$ is the coefficient of correlation between the average distance between the lender and its respective borrowers in a given year and the HP-filtered percent change in the real GDP. Real GDP series is obtained from the Federal Reserve Economic Data (FRED) website of the Federal Reserve of St. Louis. $\rho$ (Unemployment, Dist) is the coefficient of correlation between the average distance between the lender and its respective borrowers in a given year and the log difference in the US annual unemployment rate. The unemployment rate series is obtained from the Federal Reserve Economic Data (FRED) website of the Federal Reserve of St. Louis. $\rho($ Spreads, Dist) is the coefficient of correlation between the average distance between the lender and its respective borrowers in a given year and the net percentage of domestic banks increasing spreads of loan rates over banks' cost of funds to small firms. The series is obtained from the Federal Reserve Economic Data (FRED) website of the Federal Reserve of St. Louis. We use a balanced sample of banks for which we observations on distance throughout the entire period. All specifications include fixed effects based on the size-bins that the bank falls into. All banks are divided into 10 size buckets based on their total assets. Standard errors are presented in parentheses, and are robust to heteroskedasticity. ${ }^{* * *},{ }^{* *}$, and $*$, represent statistical significance at $1 \%, 5 \%$, and $10 \%$ levels, respectively.

Panel A: Summary Statistics

\begin{tabular}{lcccccccc}
\hline \hline & $\mathrm{N}$ & $\mathrm{Mean}$ & St. Dev. & $\mathrm{p} 10$ & $\mathrm{p} 25$ & $\mathrm{p} 50$ & $\mathrm{p} 75$ & $\mathrm{p} 90$ \\
\hline Av. Ret. on Bad Bank Days & 103 & -0.0333 & 0.0114 & -0.0491 & -0.0402 & -0.0332 & -0.0282 & -0.0215 \\
Av. Ret. on Bad Market Days & 103 & -0.0389 & 0.0122 & -0.0533 & -0.0463 & -0.0394 & -0.0338 & -0.0260 \\
$\rho($ GDP, Dist $)$ & 103 & 0.0607 & 0.260 & -0.279 & -0.129 & 0.0719 & 0.266 & 0.398 \\
$\rho($ Unemployment, Dist $)$ & 103 & -0.0107 & 0.251 & -0.290 & -0.163 & -0.0637 & 0.126 & 0.297 \\
$\rho$ (Spreads, Dist $)$ & 103 & -0.0229 & 0.257 & -0.302 & -0.225 & -0.0464 & 0.132 & 0.369 \\
\hline \hline
\end{tabular}

Panel B: OLS Regressions

\begin{tabular}{|c|c|c|c|c|c|c|}
\hline & (1) & $(2)$ & (3) & $(4)$ & $(5)$ & $(6)$ \\
\hline & Return & Bad Bank & Days & Return & Bad Market & t Days \\
\hline$\rho(G D P, D i s t)$ & $\begin{array}{l}-0.010^{* * *} \\
(0.004)\end{array}$ & & & $\begin{array}{l}-0.010^{* *} \\
(0.004)\end{array}$ & & \\
\hline$\rho($ Unemployment, Dist $)$ & & $\begin{array}{l}0.007^{* *} \\
(0.003)\end{array}$ & & & $\begin{array}{l}0.009^{* *} \\
(0.004)\end{array}$ & \\
\hline$\rho($ Spreads, Dist $)$ & & & $\begin{array}{c}0.005 \\
(0.003)\end{array}$ & & & $\begin{array}{l}0.007^{* *} \\
(0.003)\end{array}$ \\
\hline Observations & 103 & 103 & 103 & 103 & 103 & 103 \\
\hline Adjusted $R^{2}$ & 0.456 & 0.426 & 0.413 & 0.323 & 0.309 & 0.296 \\
\hline Baseline Controls & Yes & Yes & Yes & Yes & Yes & Yes \\
\hline
\end{tabular}




\title{
Online Appendix for Going the Extra Mile: Distant Lending and Credit Cycles
}

\author{
November 30th, 2020
}

\section{Table of Contents:}

Figure IA.1: Effects of Distance on Lending Growth over the Business Cycle (Alternative Dependent Variables)

Figure IA.2: Evolution of Lending Distances (Purging the Effects of M\&As)

Figure IA.3: Evolution of Lending Distances using distance to Population-Weighted Centroids of the County)

Figure IA.4: Histogram of Estimated Coefficients of Distance and GDP Interaction after (Excluding One State at a Time)

Figure IA.5: Evolution of Lending Distances in the Small Business Administration Dataset

Figure IA.6: Alternative Measure of Distance in the Small Business Administration Sample

Figure IA.7: Distance and Lending Growth in the SBA Dataset

Figure IA.8: Effect of Distance on Likelihood of Charge-Off by Type of SBA Program

Figure IA.9: Evolution of Loss Given Default of SBA Loans by Distance Bin

Figure IA.10: Evolution of Average Deposit Rate

Figure IA.11: Internal Capital Markets (Coefficient of Variation in Areas with low and High HHI)

Figure IA.12: Effect of Distance on Lending Growth over time (Non-Parametric Analysis of the Role of Internal Capital Markets)

Figure IA.13: Effect of Distance on Lending Growth over the Business Cycle (Non-Parametric Analysis of the role of Nonperforming Loan Ratio)

Table IA.1 Alternative Dependent Variables 
Table IA.2 Alternative Distance Indicators: Out-of-County Dummy

Table IA.3 Alternative Distance Indicators: Distance Dummies

Table IA.4 Alternative Business Cycle Indicators: State and Local Business Cycle Indicators

Table IA.5 Winsorized Dependent Variables

Table IA.6 Main Results on Subsample of Bank-County Combinations with Minimum Number of Loans

Table IA.7 Distance and Small Business Lending: Small Agricultural Loans

Table IA.8 Distance and Small Business Administration Lending: Business Cycle Indicators

Table IA.9 The Role of Market Concentration: Deposit-Based HHI

Table IA.10 The Role of Market Concentration: Shadow Bank Penetration

Table IA.11 Distance and Small Business Lending: The Role of Bank Capitalization

Table IA.12 The Role of Market Concentration (Single-County Banks)

Table IA.13 The Role of Market Concentration: Out-of-County Dummy 
Figure IA.1: Effects of Distance on Credit Growth over the Business Cycle (Alternative Dependent Variables

The top panel of Figure IA.1 represents the estimated coefficients from a regression of the log change in the number of small business loans to borrowers in a county on a series of interactions between lending distance and a set of dummy variable representing each year in the sample. Specifically, we plot the series of estimated coefficients $\beta_{t}$ and associated confidence intervals in the regression $\Delta L n(N b r . S B L)_{b c t}=\theta_{c t}+\omega_{b}+\sum_{t} \beta_{t}$ Distance $_{b c t} \times Y e a r_{t}+\Gamma X_{b t}+\epsilon_{b c t}$. The bottom figure represents the estimated coefficients from a regression of an indicator variable that takes the value of one if the bank made a loan to a borrower located in a county where the bank had not made loans the previous year on a series of interactions between lending distance and a set of dummy variable representing each year in the sample. Specifically, we plot the series of estimated coefficients $\beta_{t}$ and associated confidence intervals in the regression Start $_{b c t}=\theta_{c t}+\omega_{b}+\sum_{t} \beta_{t}$ Distance $_{b c t} \times$ Year $_{t}+\Gamma X_{b t}+\epsilon_{b c t}$. The shallow triangles connected by the dashed line represent the detrended GDP growth series (HP-filtered) Data for this figure is computed using the CRA Small Business Lending and the SOD datasets.
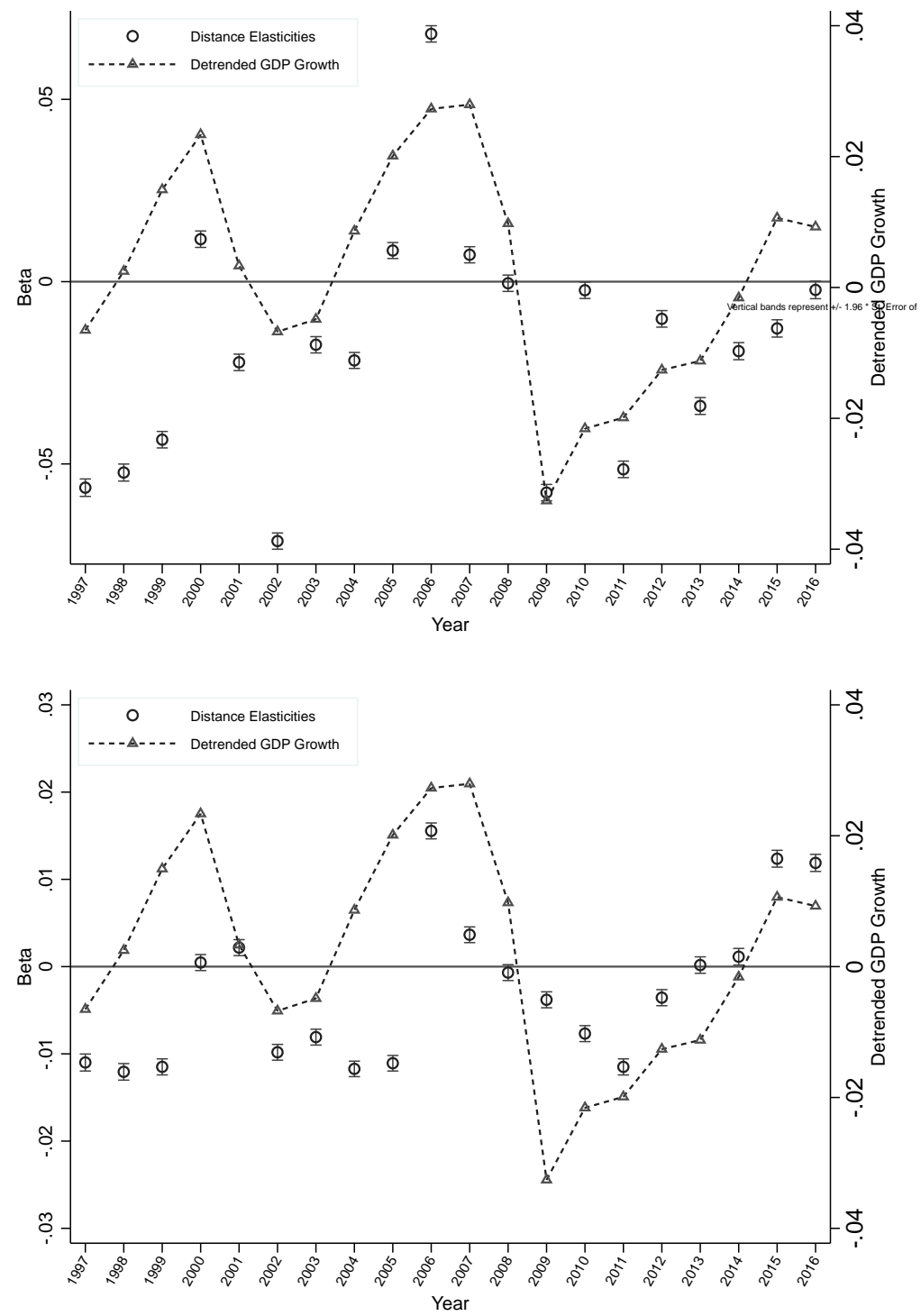


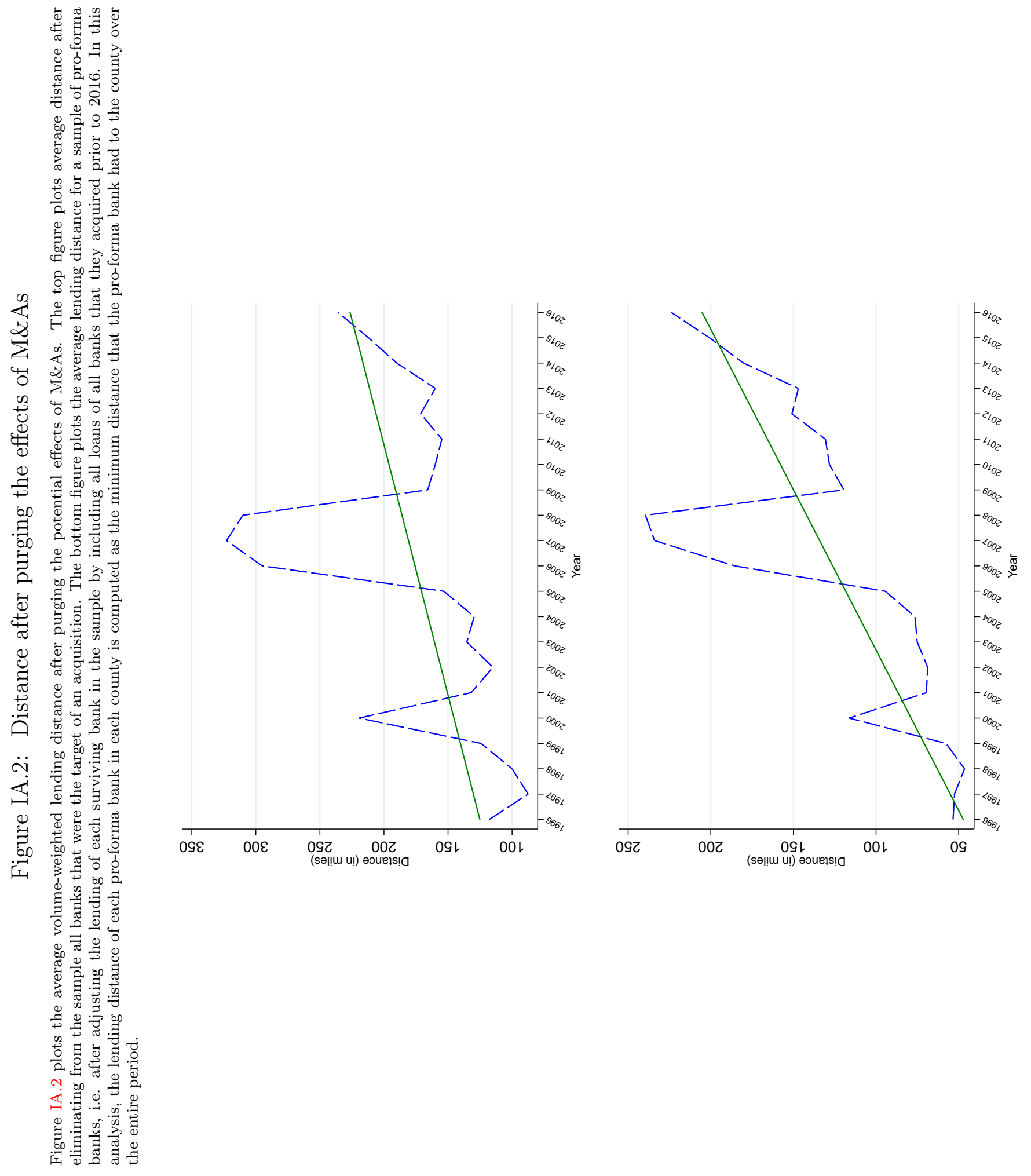


Figure IA.3: Evolution of Lending Distances using distance to Population-Weighted Centroids of the County

Figure IA. 3 plots the time-series of the average volume-weighted lending distance between lender and borrowers in the dataset. Lending Distance for each loan is computed as the geodetic distance between the borrower's population-weighted county centroid and its respective lender closest branch.

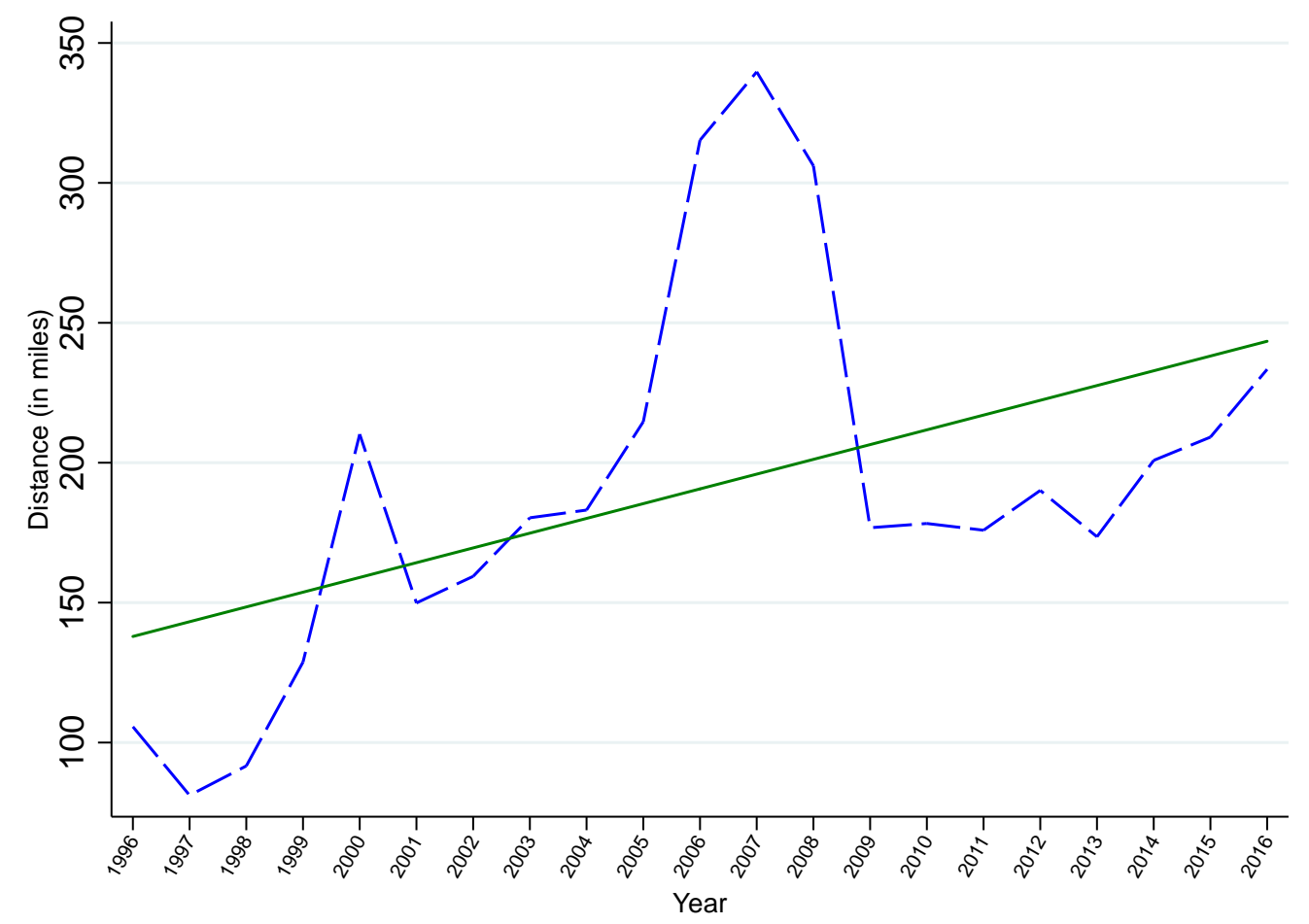


Figure IA.4: Robustness: Histogram of Estimated Coefficients of Distance and GDP Interaction after Excluding One State at a Time)

Figure IA.4 plots the estimated coefficients on the interaction between borrower-lender distance indicator and the GDP indicator after excluding one state at a time in the empirical specification of equation (1).

Change in loan volumes, distance, and the business cycle: Excluding one state at a time

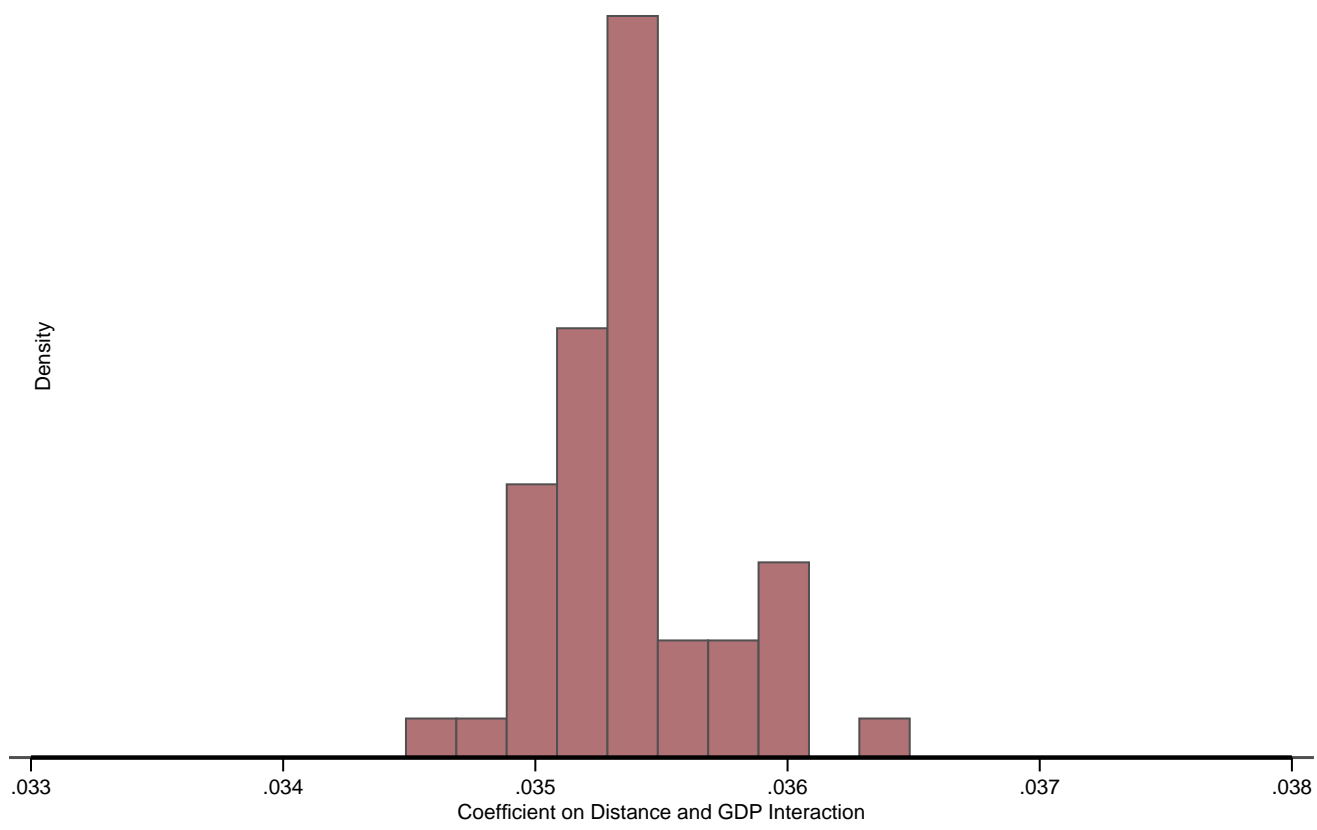




\section{Figure IA.5: Evolution of Lending Distances in the Small Business Administration Dataset}

Figure IA.5 shows two plots. Panel A plots the average distance of all small business administration loans over time. Lending Distance for each loan is computed as the geodetic distance between the lender and borrower addresses listed on the SBA dataset. Panel B plots the bank equal-weighted lending distance over time. To compute the bank equal-weighted lending distance, we initially compute the average lending distance for each bank-year combination and then average across all banks in each year. Data for all figures is obtained from the Small Business Administration.

Panel A: Average Lending Distance (Volume-Weighted)

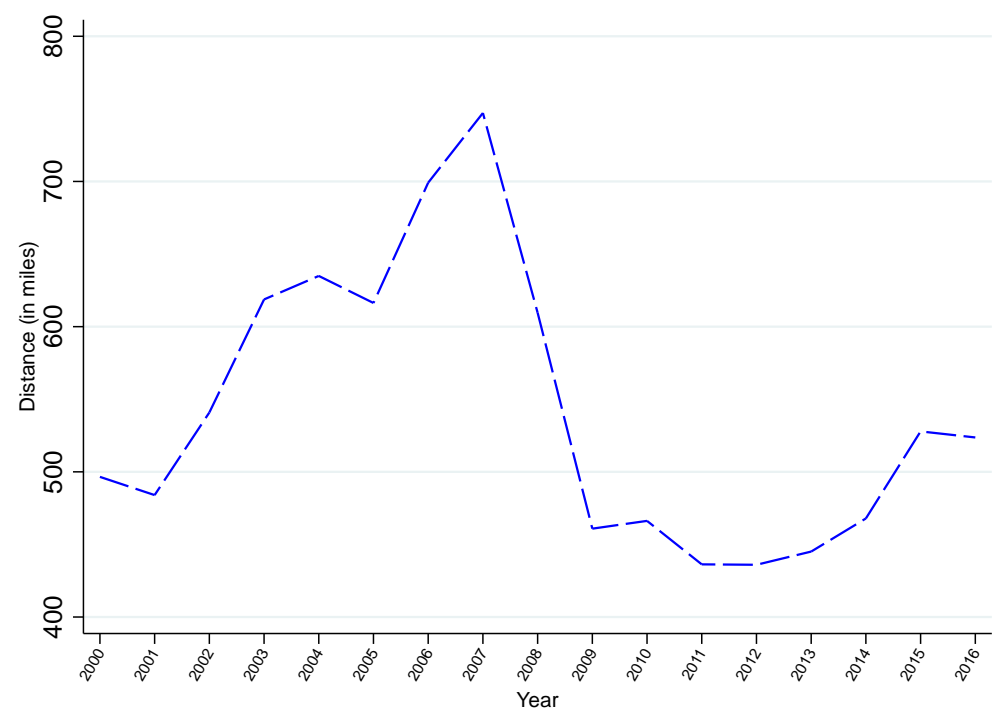

Panel B: Average Lending Distance (Equal-Weighted across Banks)

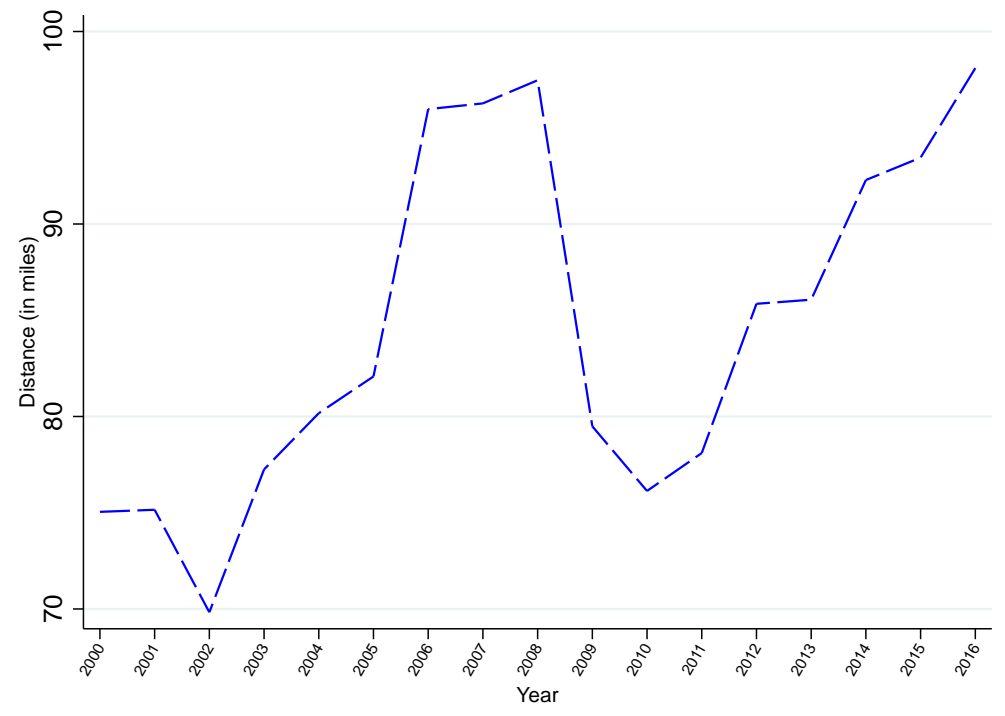


Figure IA.6: Robustness: Alternative Measure of Distance in the Small Business Administration Sample

Figure IA.6 plots the effect of distance between the borrower and lender in the SBA dataset over time. To compute distances, we hand-match all lenders with more that 500 SBA loans to the Summary of Deposits dataset and we compute distance as the minimum distance between the borrowers' address and their respective lender closest branch. The plot shows the same boom-bust pattern in average distance around the recent financial crisis.

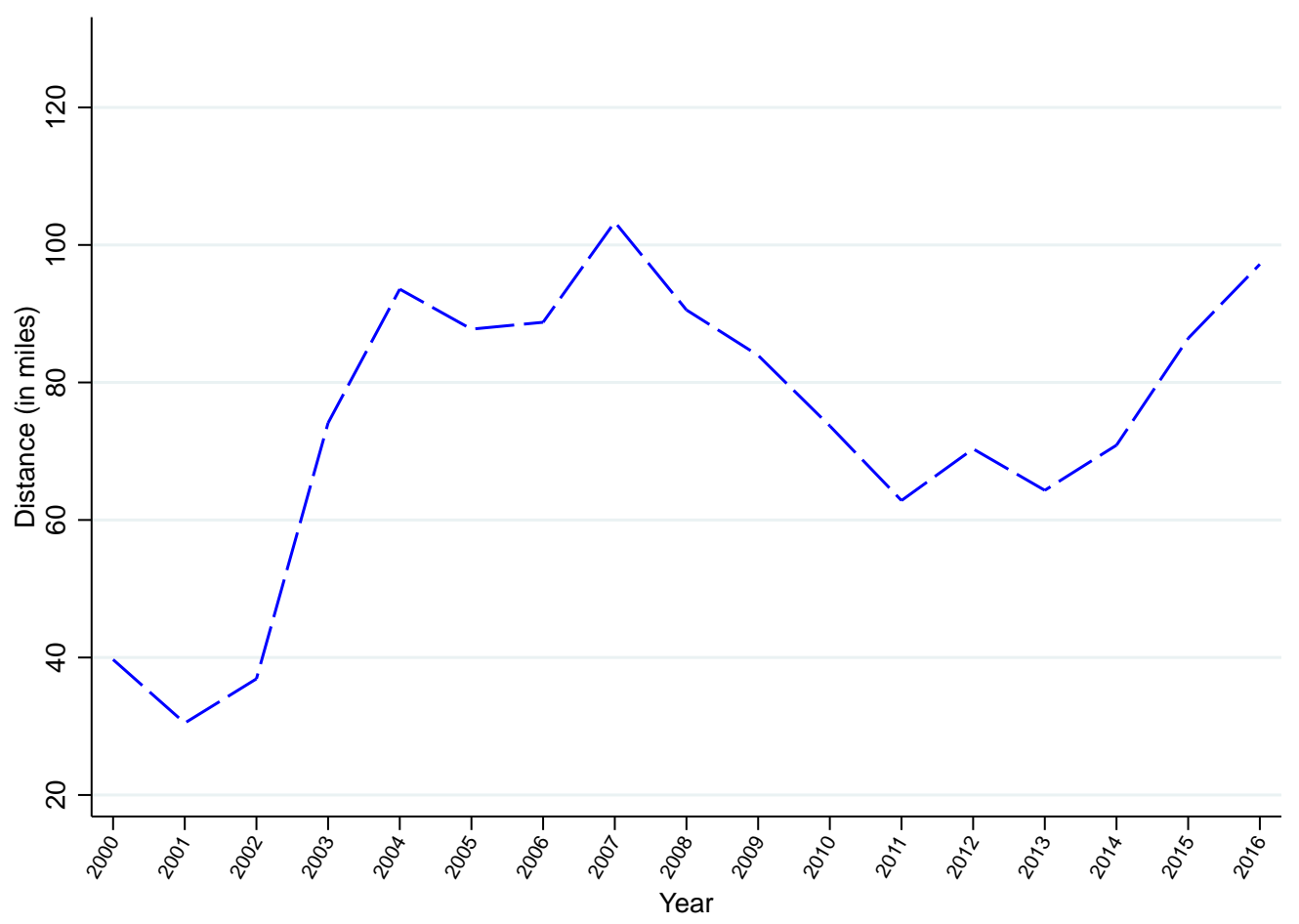




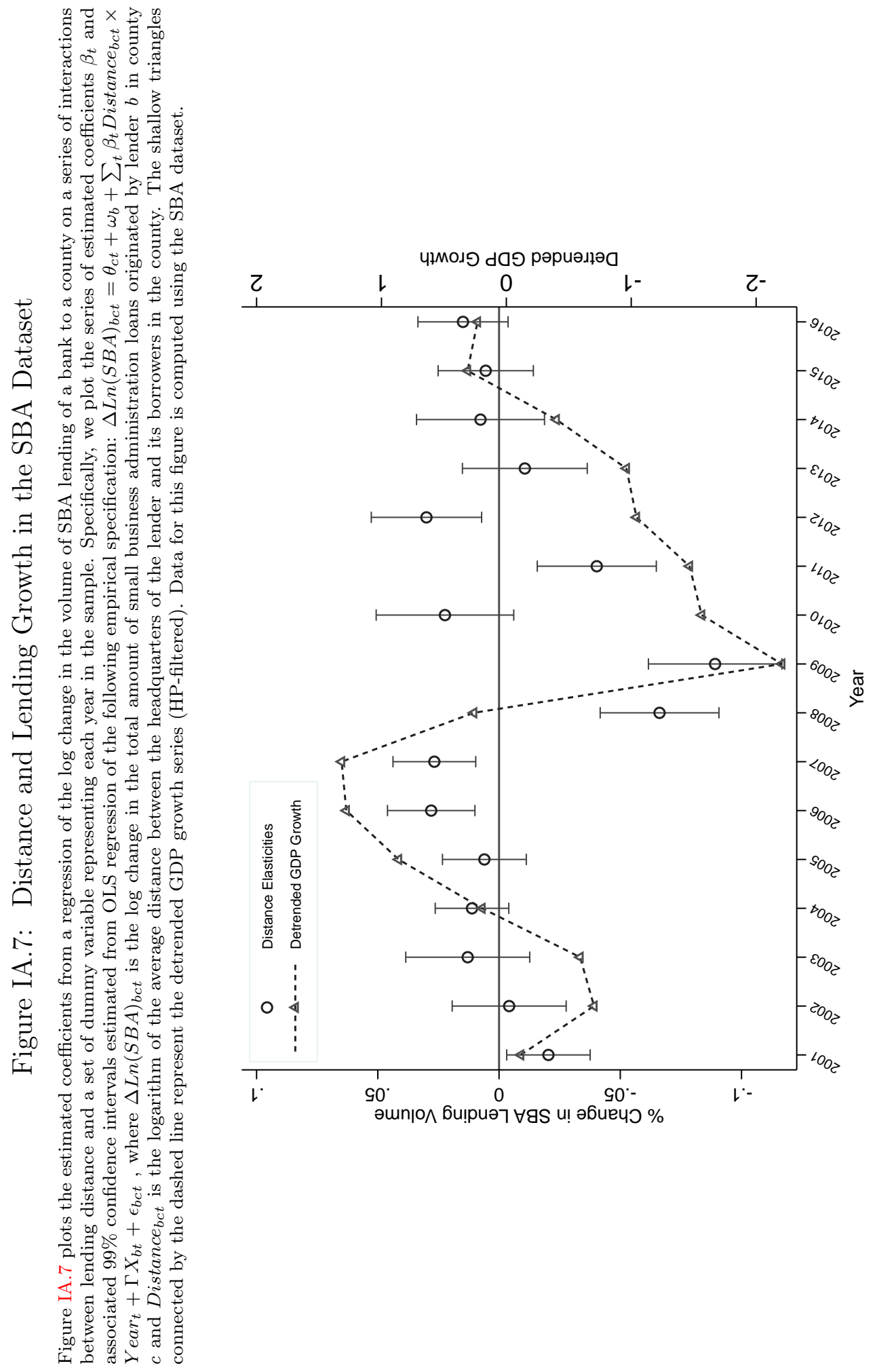




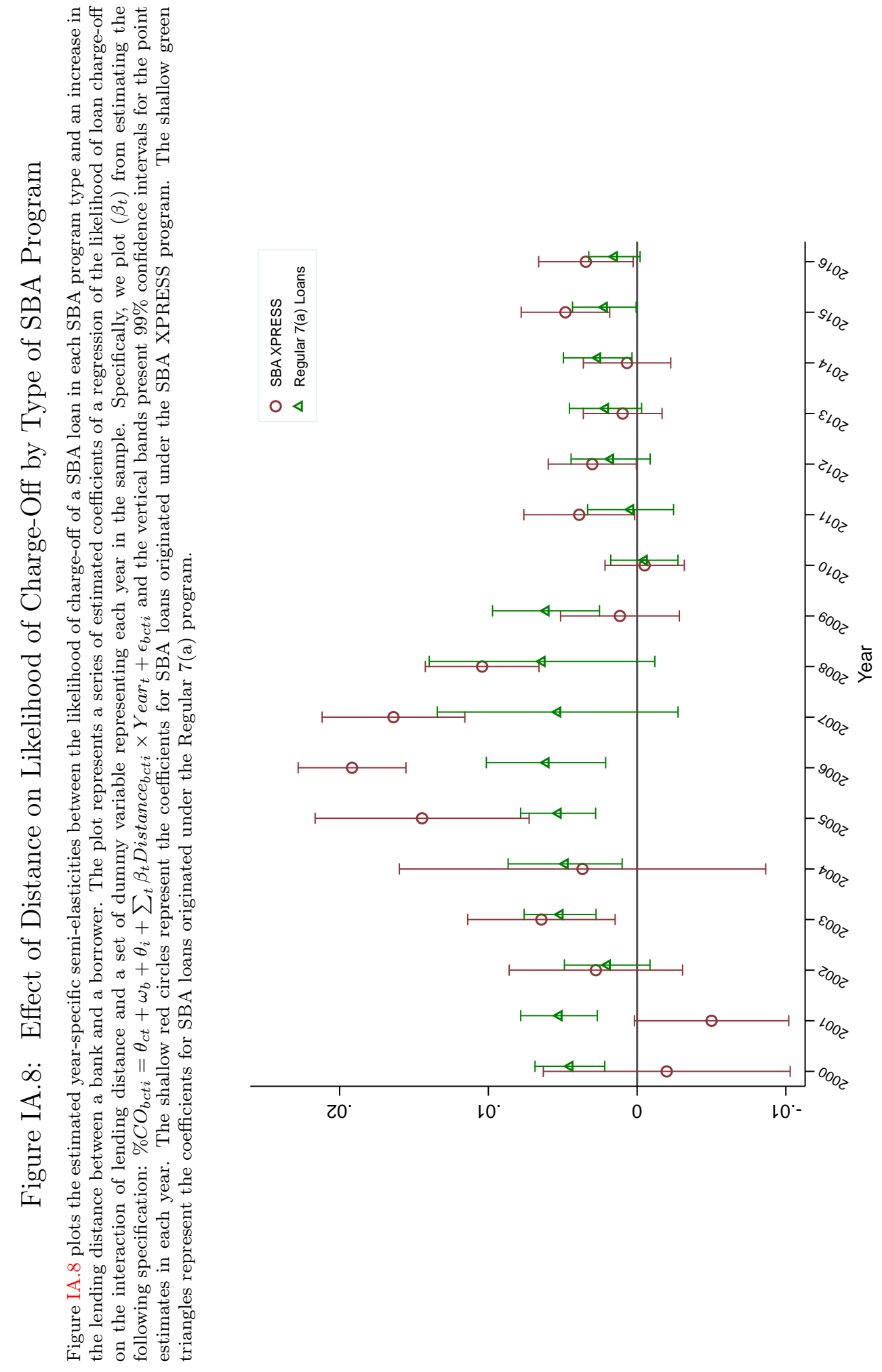



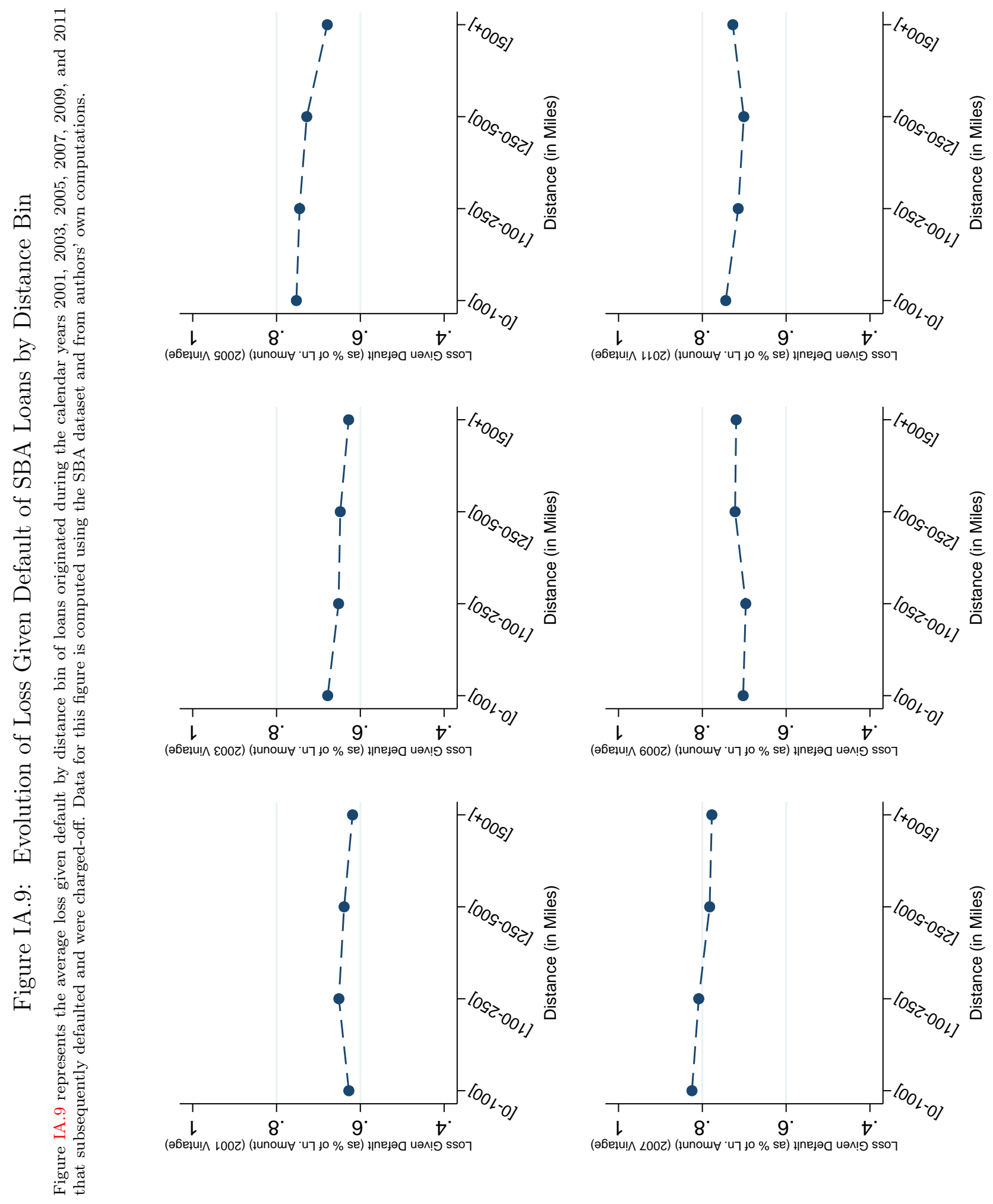


\section{Figure IA.10: Evolution of Average Deposit Rate}

Figure IA.10 plots the evolution of banks' average costs of funding. The green line represents the average interest expense rate computed using Call Report data. This rate is the total interest expense (including interest expense on deposits, wholesale funding, and other liabilities) divided by total assets. The red line is the average advertised rate of the 1-year certificates of deposit with minimum deposit of $\$ 10,000$ obtained from RateWatch.

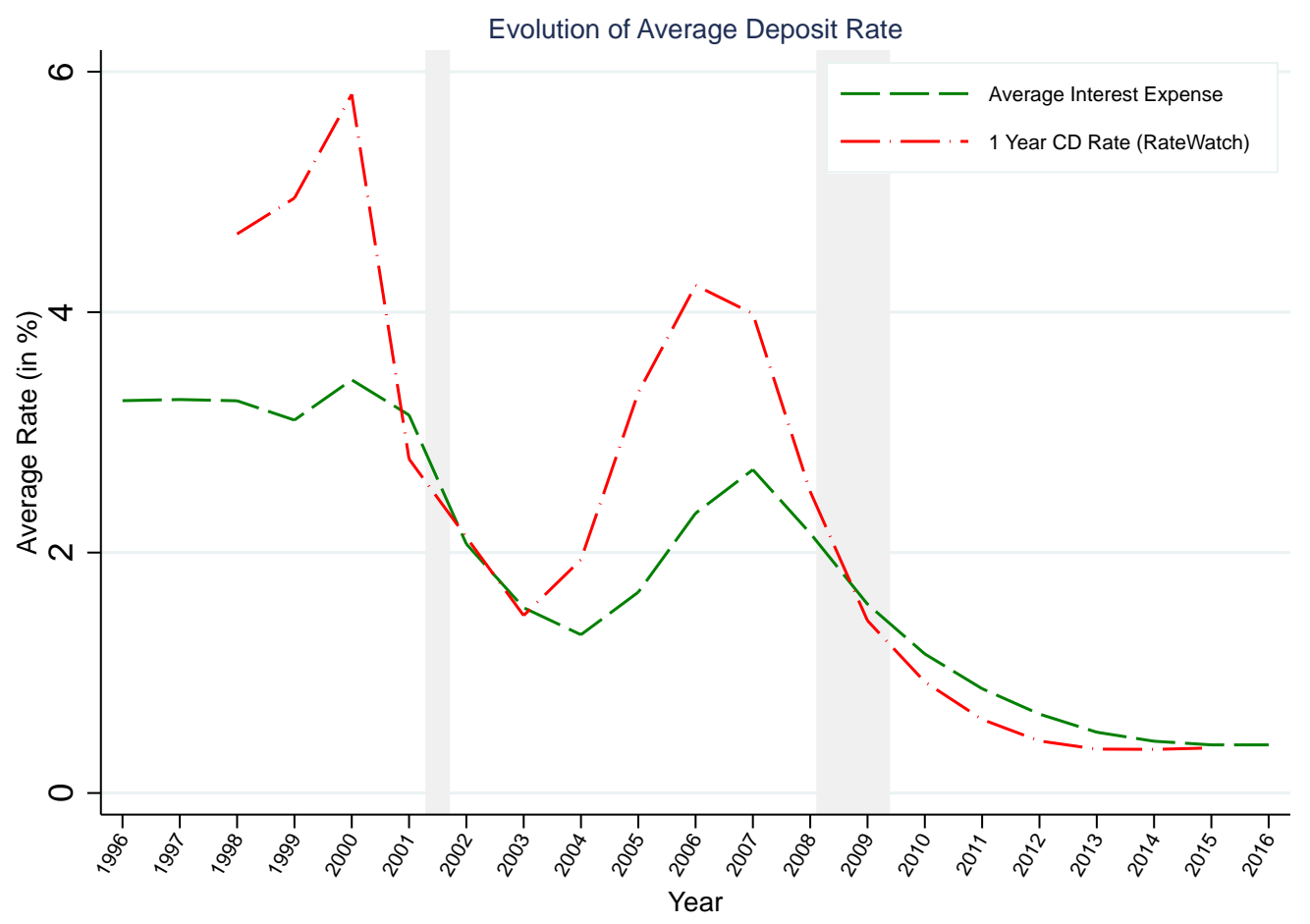




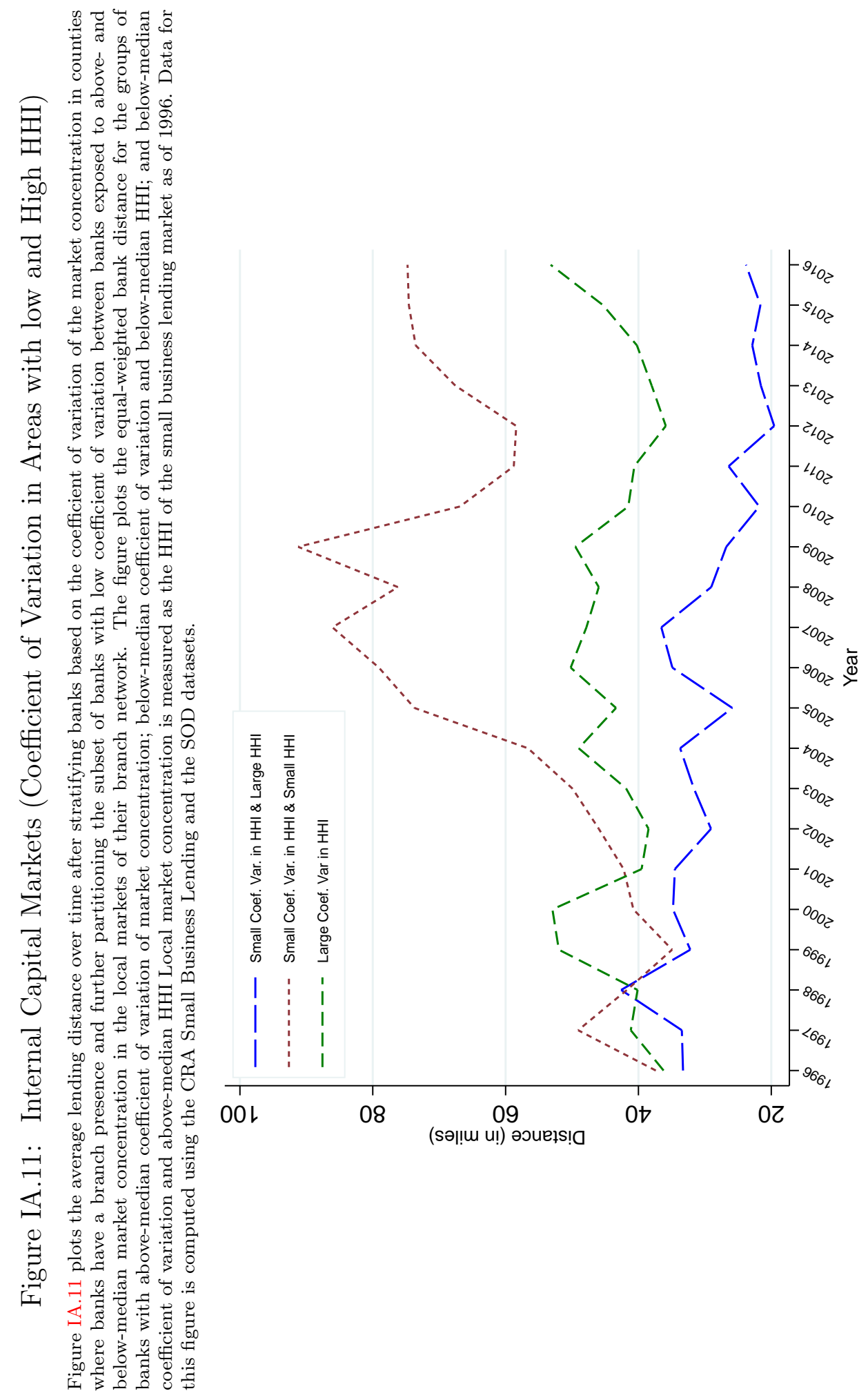




\section{Figure IA.12: Distance and Lending Growth over the Business Cycle (Non-Parametric Analysis of Role of Internal Capital Markets)}

Figure IA.12 represents the evolution over time of the estimated marginal effect of distance on changes in bank lending measured at different points of the distribution of the HHI coefficient of variation of banks. We compute the marginal effects of distance over time using estimates from the following empirical specification: $\Delta \operatorname{Ln}(S B L)_{b c t}=\theta_{c t}+\omega_{b}+\sum_{t} \gamma_{t}(\text { Distance } \times \text { Year })_{b c t}+\sum_{t} \lambda_{t}($ Distance $\times$ $Y$ ear $\left.\times \sigma H H I_{b c t}\right)+\Gamma X_{b t}+\epsilon_{b c t}$, where $\sigma H H I_{b c t}$ is the coefficient of variation of the HHI in the branch network of the bank. The marginal effects are computed using the year-specific elasticities of loan volume with respect to distance $\left(\hat{\gamma}_{t}\right)$ and the year-specific elasticities of loan volume with respect to distance interacted with $\sigma H H I\left(\hat{\lambda}_{t}\right)$. Specifically, we plot $\hat{\gamma}_{t}+\hat{\lambda}_{t} \times \sigma H H I$, where $t=1996, \ldots 2016$, and $\sigma H H I$ takes values $\{\mu-2 \sigma, \mu+2 \sigma\}$, where $\mu$ is the mean value of $\sigma H H I$ over the entire sample and $\sigma$ is the standard deviation of $\sigma H H I$ over the entire sample. The green dashed line is the elasticity of the volume of loans over time for a representative bank-county pair whose value of $\sigma H H I$ is two standard deviations above the mean. The solid red line is the elasticity of the volume of loans over time for a representative bank-county pair whose value of $\sigma H H I$ is two standard deviations below the mean. Data for this figure is computed using the CRA Small Business Lending and the SOD datasets.

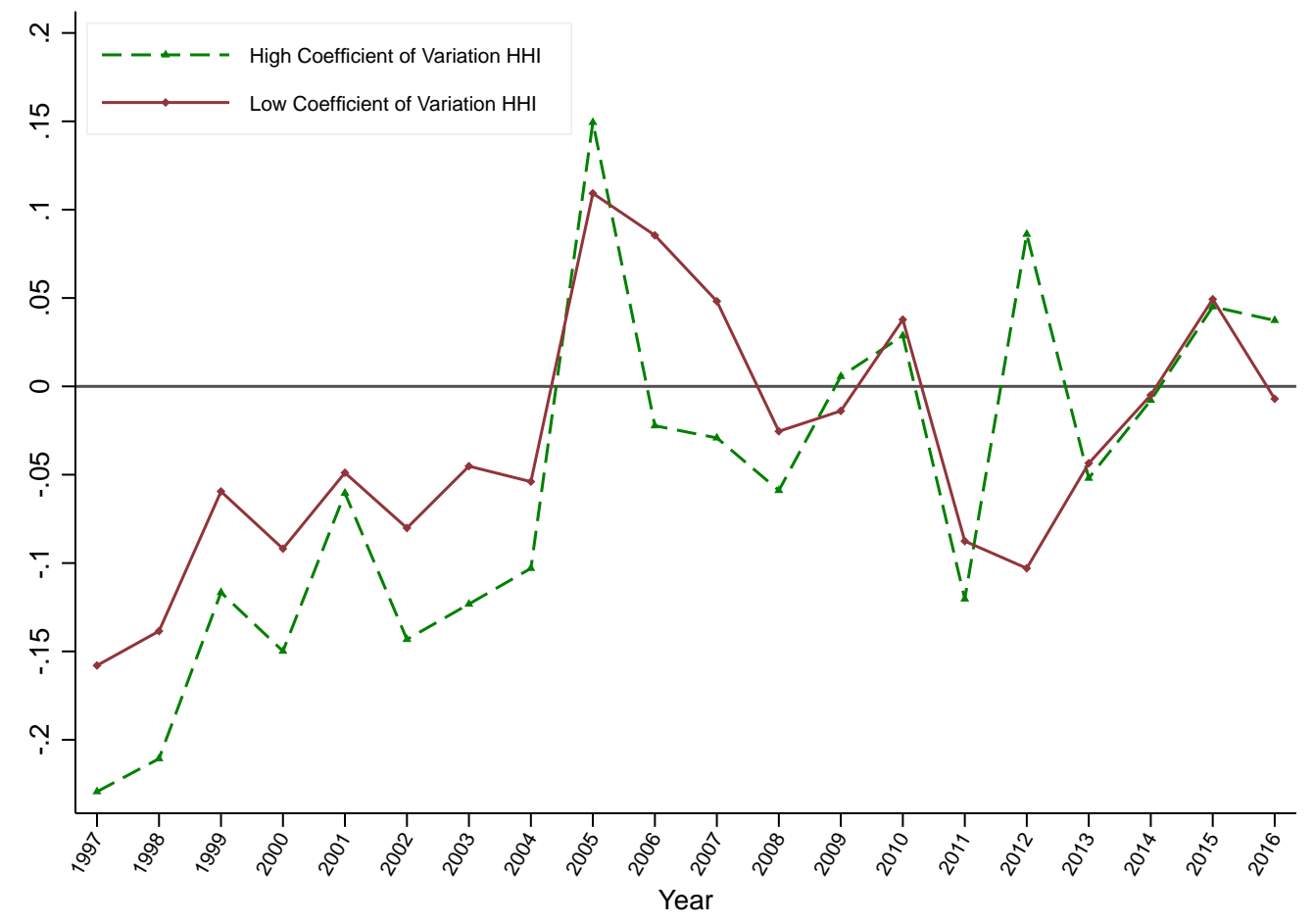




\section{Figure IA.13: Distance and Lending Growth over the Business Cycle (Non-Parametric Analysis of}

Nonperforming Loan Ratio)

Figure IA.13 plots the incremental contribution of the nonperforming loan ratio on the estimated marginal effect of distance on the log change in volume of loans. We compute the marginal effects of distance over time using estimates from the following empirical specification: $\Delta \operatorname{Ln}(S B L)_{b c t}=\theta_{c t}+\omega_{b}+\sum_{t} \gamma_{t}(\text { Distance } \times Y \text { ear })_{b c t}+\sum_{t} \lambda_{t}\left(\right.$ Distance $\times Y$ ear $\left.\times N P L_{b t}\right)+\Gamma X_{b t}+\epsilon_{b c t}$. The marginal effects are computed using the year-specific elasticities of loan volume with respect to distance $\left(\hat{\gamma}_{t}\right)$ and the year-specific elasticities of loan volume with respect to distance interacted with $N P L\left(\hat{\lambda}_{t}\right)$. Specifically, we plot $\hat{\gamma}_{t}+\hat{\lambda}_{t} \times N P L$, where $t=1996, \ldots 2016$, and $N P L$ takes values $\{\mu-2 \sigma, \mu+2 \sigma\}$, where $\mu$ is the mean value of $N P L$ over the entire sample and $\sigma$ is the standard deviation of $N P L$. The green dashed line is the elasticity of the volume of loans over time for a representative bank with $N P L s$ two standard deviations above the mean. The solid red line is the elasticity of the volume of loans over time for a representative bank with NPLs two standard deviations below the mean. Data for this figure is computed using the CRA Small Business Lending and the SOD datasets.

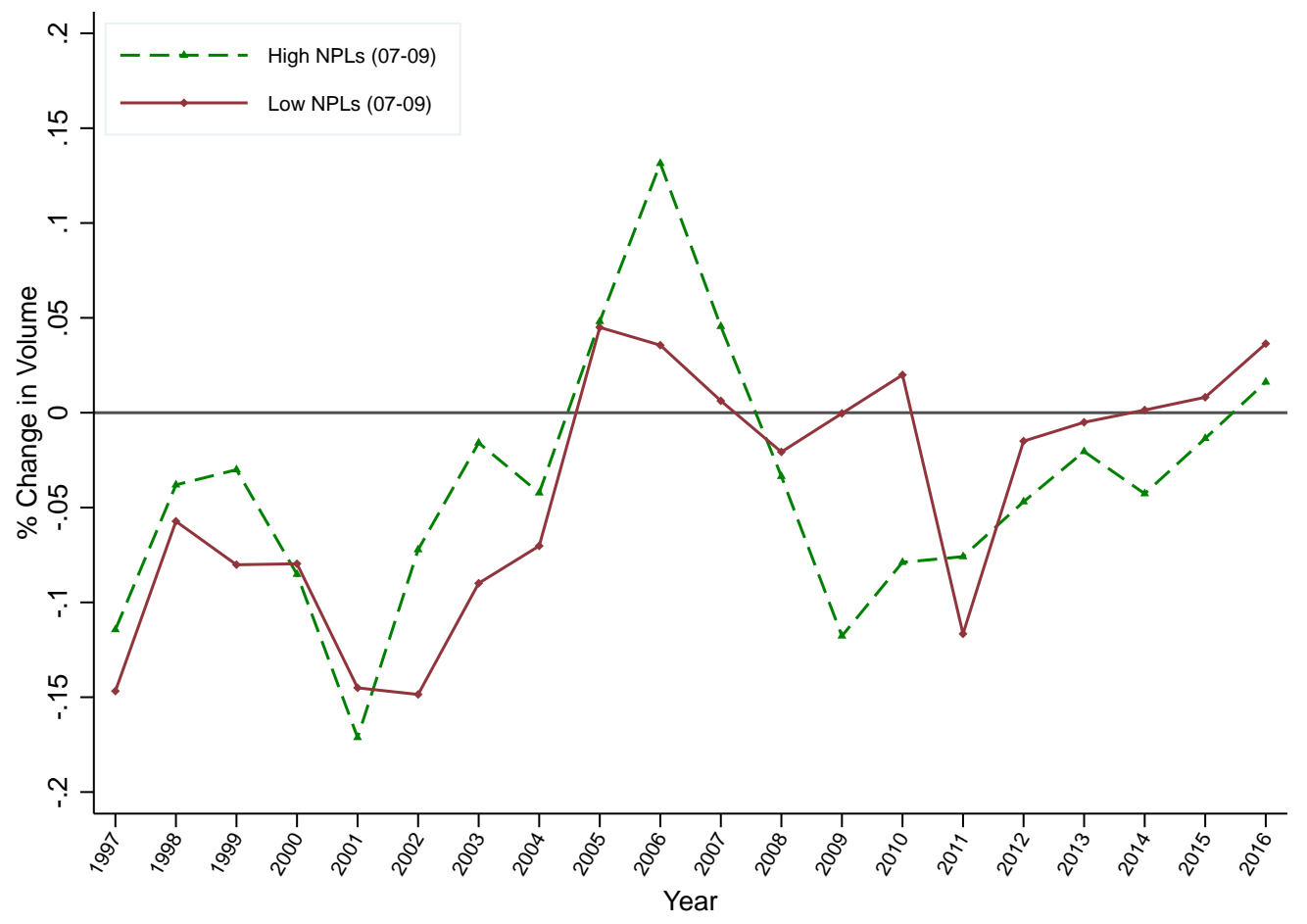




\section{Table IA.1: Alternative Dependent Variables}

$\Delta \operatorname{Ln}(\mathrm{Nbr} . \mathrm{SBL})$ is the change in the natural logarithm of one plus the total number of small business loans originated by a bank to small businesses located in a county during a calendar year. Exit is an indicator variable that takes the value of one if the bank stopped lending to a county where the bank had originated a loan during the previous year. $\Delta L n(S B L) \leq 100 k$ is the change in the natural logarithm of one plus the total amount of small business loans with principal amount below $\$ 100,000$ originated by a bank to small businesses located in a county during a calendar year. $100 k \leq \Delta L n(S B L) \leq 1 M$ is the change in the natural logarithm of one plus the total amount of small business loans with principal amount between $\$ 100,000$ and $\$ 1 \mathrm{M}$ originated by a bank to small businesses located in a county during a calendar year. HP-Filtered Real GDP is the standardized HP-filtered percent change in the real GDP. Real GDP series is obtained from the Federal Reserve Economic Data (FRED) website of the Federal Reserve of St. Louis. Ln(Distance) is the natural logarithm of the minimum distance between the bank's branch network and the county centroid. All specifications include county-by-year and bank fixed-effects as well as baseline controls for natural logarithm of Total Assets, Share of Commercial \& Real Estate Loans, Share of Residential Loans, and Share of Commercial \& Industrial Loans. Standard errors are presented in parentheses, and are clustered at the level of the county. $* * *, * *$, and $*$, represent statistical significance at $1 \%, 5 \%$, and $10 \%$ levels, respectively.

\begin{tabular}{|c|c|c|c|c|c|}
\hline & $\begin{array}{c}(1) \\
\Delta \operatorname{Ln}(\mathrm{Nbr} . \mathrm{SBL})\end{array}$ & $\begin{array}{l}(2) \\
\text { Start }\end{array}$ & $\begin{array}{c}(3) \\
\text { Exit }\end{array}$ & $\begin{array}{r}(4) \\
\Delta \operatorname{Ln}(\mathrm{SBL}) \leq 100 \mathrm{k}\end{array}$ & $100 \mathrm{k} \leq \Delta \operatorname{Ln}(\mathrm{SBL}) \leq 1 \mathrm{M}$ \\
\hline \multirow[t]{2}{*}{ Ln(Distance) } & $-0.019^{* * *}$ & $-0.003^{* * *}$ & $0.000^{*}$ & $-0.032^{* * *}$ & $-0.041^{* * *}$ \\
\hline & $(0.000)$ & $(0.000)$ & $(0.000)$ & $(0.000)$ & $(0.001)$ \\
\hline \multirow[t]{2}{*}{ Ln $($ Distance $) \times$ HP-Filtered Real GDP } & $0.020 * * *$ & $0.003^{* * *} *$ & $-0.002^{* * *}$ & $0.031^{* * * *}$ & $0.005 * * *$ \\
\hline & $(0.000)$ & $(0.000)$ & $(0.000)$ & $(0.001)$ & $(0.001)$ \\
\hline Observations & 5234549 & 5234549 & 5234549 & 5234549 & 5234549 \\
\hline Adjusted $R^{2}$ & 0.038 & 0.032 & 0.027 & 0.024 & 0.005 \\
\hline Baseline Controls & Yes & Yes & Yes & Yes & Yes \\
\hline Bank Fixed Effects & Yes & Yes & Yes & Yes & Yes \\
\hline County-Year Fixed Effects & Yes & Yes & Yes & Yes & Yes \\
\hline
\end{tabular}




\section{Table IA.2: Alternative Distance Indicators: Out-of-County Dummy}

The dependent variable, $\Delta L n(S B L)$, is the change in the natural logarithm of one plus the total amount of small business loans originated by a bank to small businesses located in a county during a calendar year. HP-Filtered Real GDP is the standardized HP-filtered percent change in the real GDP. Real GDP series is obtained from the Federal Reserve Economic Data (FRED) website of the Federal Reserve of St. Louis. $\Delta$ Ln (Unempld Rate) is standardized log difference in the US annual unemployment rate. The unemployment rate series is obtained from the FRED website. Spreads is the standardized net percentage of domestic banks increasing spreads of loan rates over banks' cost of funds to small firms obtained from the FRED website. Out-County Dummy is an indicator variable that takes the value of one if the borrower is located in a county where the bank does not have a branch presence. The specification includes county-by-year and bank fixed-effects as well as baseline controls for natural logarithm of Total Assets, Share of Commercial \& Real Estate Loans, Share of Residential Loans, and Share of Commercial \& Industrial Loans. Standard errors are presented in parentheses, and are clustered at the level of the county. ${ }^{* *},{ }^{* *}$, and $*$, represent statistical significance at $1 \%, 5 \%$, and $10 \%$ levels, respectively.

\begin{tabular}{|c|c|c|c|}
\hline & $\begin{array}{ll}(1) & \\
& \Delta\end{array}$ & $\begin{array}{c}(2) \\
\operatorname{Ln}(\mathrm{SBL})\end{array}$ & (3) \\
\hline Out-County Dummy & $\begin{array}{l}-0.152^{* * *} \\
(0.003)\end{array}$ & $\begin{array}{l}-0.154^{* * *} \\
(0.003)\end{array}$ & $\begin{array}{l}-0.158^{* * *} \\
(0.003)\end{array}$ \\
\hline Out-County Dummy $\times$ HP-Filtered Real GDP & $\begin{array}{l}0.066^{* * * *} \\
(0.004)\end{array}$ & & \\
\hline Out-County Dummy $\times \Delta \operatorname{Ln}($ Unempld Rate $)$ & & $\begin{array}{l}-0.034^{* * *} \\
(0.003)\end{array}$ & \\
\hline Out-County Dummy $\times$ Spreads & & & $\begin{array}{l}-0.074^{* * *} \\
(0.003)\end{array}$ \\
\hline Observations & 5234549 & 5234549 & 5234549 \\
\hline Adjusted $R^{2}$ & 0.016 & 0.016 & 0.017 \\
\hline Baseline Controls & Yes & Yes & Yes \\
\hline Bank Fixed Effects & Yes & Yes & Yes \\
\hline County-Year Fixed Effects & Yes & Yes & Yes \\
\hline
\end{tabular}




\section{Table IA.3: Alternative Distance Indicators: Distance Dummies}

The dependent variable, $\Delta L n(S B L)$, is the change in the natural logarithm of one plus the total amount of small business loans originated by a bank to small businesses located in a county during a calendar year. HP-Filtered Real GDP is the standardized HP-filtered percent change in the real GDP. Real GDP series is obtained from the Federal Reserve Economic Data (FRED) website of the Federal Reserve of St. Louis. I(Distance > 25 miles) is an indicator variable that takes the value of one if the lending distance between borrower and lender exceeds 25 miles. I(Distance $>50$ miles) is an indicator variable that takes the value of one if the lending distance between borrower and lender exceeds 50 miles. I(Distance $>100$ miles) is an indicator variable that takes the value of one if the lending distance between borrower and lender exceeds 100 miles. I(Distance $>250$ miles) is an indicator variable that takes the value of one if the lending distance between borrower and lender exceeds 250 miles. The specification includes county-by-year and bank fixed-effects as well as baseline controls for natural logarithm of Total Assets, Share of Commercial \& Real Estate Loans, Share of Residential Loans, and Share of Commercial \& Industrial Loans. Standard errors are presented in parentheses, and are clustered at the level of the county. ***, **, and $*$, represent statistical significance at $1 \%, 5 \%$, and $10 \%$ levels, respectively.

\begin{tabular}{|c|c|c|c|c|}
\hline & \multicolumn{4}{|c|}{$\Delta \operatorname{Ln}(\mathrm{SBL})$} \\
\hline I(Distance $>25$ miles $)$ & $\begin{array}{l}-0.135^{* * *} \\
(0.002)\end{array}$ & & & \\
\hline I $($ Distance $>25$ miles $) \times$ HP-Filtered Real GDP & $\begin{array}{l}0.074^{* * *} \\
(0.003)\end{array}$ & & & \\
\hline I(Distance $>50$ miles $)$ & & $\begin{array}{l}-0.123^{* * *} \\
(0.002)\end{array}$ & & \\
\hline $\mathrm{I}($ Distance $>50$ miles $) \times$ HP-Filtered Real GDP & & $\begin{array}{l}0.085^{* * *} \\
(0.002)\end{array}$ & & \\
\hline I(Distance >100 miles) & & \multirow{2}{*}{\multicolumn{3}{|c|}{$\begin{array}{l}-0.109^{* * *} \\
(0.002) \\
0.094^{* * *} \\
(0.002)\end{array}$}} \\
\hline I (Distance $>100$ miles $) \times$ HP-Filtered Real GDP & & & & \\
\hline I(Distance $>250$ miles $)$ & & & & $\begin{array}{l}-0.089^{* * *} \\
(0.002)\end{array}$ \\
\hline I (Distance $>250$ miles $) \times$ HP-Filtered Real GDP & & & & $\begin{array}{l}0.111^{* * *} \\
(0.002)\end{array}$ \\
\hline Observations & 5234549 & 5234549 & 5234549 & 5234549 \\
\hline Adjusted $R^{2}$ & 0.017 & 0.017 & 0.017 & 0.017 \\
\hline Baseline Controls & Yes & Yes & Yes & Yes \\
\hline Bank Fixed Effects & Yes & Yes & Yes & Yes \\
\hline County-Year Fixed Effects & Yes & Yes & Yes & Yes \\
\hline
\end{tabular}




\section{Table IA.4: Alternative Business Cycle Indicators: State and Local Business Cycle Indicators}

The dependent variable, $\Delta L n(S B L)$, is the change in the natural logarithm of one plus the total amount of small business loans originated by a bank to small businesses located in a county during a calendar year. HP-Filtered Real GDP is the standardized HP-filtered percent change in the real GDP. Real GDP series is obtained from the Federal Reserve Economic Data (FRED) website of the Federal Reserve of St. Louis. HP-Filtered State Income p.c. is the standardized HP-filtered percent change in the state-level personal income per capita. The state-level personal income per capita series is obtained from the Bureau of Economic Analysis. HP-Filtered County Income p.c. is the standardized HP-filtered percent change in the county-level personal income per capita. The county-level personal income per capita series is obtained from the Bureau of Economic Analysis. Ln(Distance) is the natural logarithm of the minimum distance between the bank's branch network and the county centroid. The specification includes county-by-year and bank fixed-effects as well as baseline controls for natural logarithm of Total Assets, Share of Commercial \& Real Estate Loans, Share of Residential Loans, and Share of Commercial \& Industrial Loans. Standard errors are presented in parentheses, and are clustered at the level of the county. ${ }^{* * *}, * *$, and *, represent statistical significance at $1 \%, 5 \%$, and $10 \%$ levels, respectively.

\begin{tabular}{|c|c|c|c|c|c|}
\hline & (1) & $\begin{array}{ll}(2) & \\
& \Delta\end{array}$ & $\begin{array}{c}(3) \\
\operatorname{Ln}(\mathrm{SBL})\end{array}$ & (4) & (5) \\
\hline Ln(Distance) & $\begin{array}{l}-0.037^{* * *} \\
(0.001)\end{array}$ & $\begin{array}{l}-0.038^{* * *} \\
(0.001)\end{array}$ & $\begin{array}{l}-0.038^{* * *} \\
(0.001)\end{array}$ & $\begin{array}{l}-0.038^{* * *} \\
(0.001)\end{array}$ & $\begin{array}{l}-0.038^{* * *} \\
(0.001)\end{array}$ \\
\hline Ln(Distance $) \times$ HP-Filtered State Real GDP & $\begin{array}{l}0.030^{* * *} \\
(0.001)\end{array}$ & & & $\begin{array}{l}0.011^{* * *} \\
(0.001)\end{array}$ & \\
\hline Ln(Distance) $\times$ HP-Filtered State Income p.c. & & $\begin{array}{l}0.017^{* * *} \\
(0.001)\end{array}$ & & & $\begin{array}{l}-0.006^{* * *} \\
(0.001)\end{array}$ \\
\hline Ln $($ Distance $) \times$ HP-Filtered County Income p.c. & & & $\begin{array}{l}0.004^{* * *} \\
(0.001)\end{array}$ & & $\begin{array}{l}-0.003^{* * *} \\
(0.001)\end{array}$ \\
\hline Ln(Distance $) \times$ HP-Filtered Real GDP & & & & $\begin{array}{l}0.029 * * * \\
(0.001)\end{array}$ & $\begin{array}{l}0.040^{* * *} \\
(0.001)\end{array}$ \\
\hline Observations & 5217323 & 5148119 & 5146638 & 5217323 & 5146638 \\
\hline Adjusted $R^{2}$ & 0.017 & 0.017 & 0.017 & 0.018 & 0.017 \\
\hline Baseline Controls & Yes & Yes & Yes & Yes & Yes \\
\hline Bank Fixed Effects & Yes & Yes & Yes & Yes & Yes \\
\hline County-Year Fixed Effects & Yes & Yes & Yes & Yes & Yes \\
\hline
\end{tabular}




\section{Table IA.5: Robustness: Winsorized Dependent Variables}

$\Delta \operatorname{Ln}(S B L)$, is the Winsorized change in the natural logarithm of one plus the total amount of small business loans originated by a bank to small businesses located in a county during a calendar year. We Winsorize the dependent variable at the top and bottom percentile. HP-Filtered Real GDP is the standardized HP-filtered percent change in the real GDP. Real GDP series is obtained from the Federal Reserve Economic Data (FRED) website of the Federal Reserve of St. Louis. $\Delta$ Ln(Unempld Rate) is standardized log difference in the US annual unemployment rate. The unemployment rate series is obtained from the FRED website. Spreads is the standardized net percentage of domestic banks increasing spreads of loan rates over banks' cost of funds to small firms obtained from the FRED website. Ln(Distance) is the natural logarithm of the minimum distance between the bank's branch network and the county centroid. The specification includes county-by-year and bank fixed-effects as well as baseline controls for natural logarithm of Total Assets, Share of Commercial \& Real Estate Loans, Share of Residential Loans, and Share of Commercial \& Industrial Loans. Standard errors are presented in parentheses, and are clustered at the level of the county. ${ }^{* *}, * *$, and $*$, represent statistical significance at $1 \%, 5 \%$, and $10 \%$ levels, respectively.

\begin{tabular}{|c|c|c|c|}
\hline & $\begin{array}{l}(1) \\
\Delta\end{array}$ & $\begin{array}{c}(2) \\
\mathrm{Ln}(\mathrm{SBL})\end{array}$ & (3) \\
\hline$\overline{L n}$ (Distance) & $\begin{array}{l}-0.033^{* * *} \\
(0.000)\end{array}$ & $\begin{array}{l}-0.032^{* * *} \\
(0.000)\end{array}$ & $\begin{array}{l}-0.033^{* * *} \\
(0.000)\end{array}$ \\
\hline Ln $($ Distance $) \times$ HP-Filtered Real GDP & $\begin{array}{l}0.033^{* * *} \\
(0.001)\end{array}$ & & \\
\hline $\operatorname{Ln}($ Distance $) \times \Delta \operatorname{Ln}($ Unempld Rate $)$ & & $\begin{array}{l}-0.018^{* * *} \\
(0.000)\end{array}$ & \\
\hline $\operatorname{Ln}($ Distance $) \times$ Spreads & & & $\begin{array}{l}-0.015^{* * *} \\
(0.000)\end{array}$ \\
\hline Observations & 5234549 & 5234549 & 5234549 \\
\hline Adjusted $R^{2}$ & 0.017 & 0.017 & 0.016 \\
\hline Baseline Controls & Yes & Yes & Yes \\
\hline Bank Fixed Effects & Yes & Yes & Yes \\
\hline County-Year Fixed Effects & Yes & Yes & Yes \\
\hline
\end{tabular}


Table IA.6: Robustness: Main Results on Subsample of Bank-County Combinations with Minimum Number of Loans

In each column, we repeat the main specification in the paper in subsamples of counties-bank combinations totaling a minimum number of loan originations throughout the entire sample period. The dependent variable, $\Delta \operatorname{Ln}(S B L)$, is the change in the natural logarithm of one plus the total amount of small business loans originated by a bank to small businesses located in a county during a calendar year. HP-Filtered Real GDP is the standardized HP-filtered percent change in the real GDP. Real GDP series is obtained from the Federal Reserve Economic Data (FRED) website of the Federal Reserve of St. Louis. Ln(Distance) is the natural logarithm of the minimum distance between the bank's branch network and the county centroid. The specification includes county-by-year and bank fixed-effects as well as baseline controls for natural logarithm of Total Assets, Share of Commercial \& Real Estate Loans, Share of Residential Loans, and Share of Commercial \& Industrial Loans. Standard errors are presented in parentheses, and are clustered at the level of the county. $* * *, * *$, and $*$, represent statistical significance at $1 \%, 5 \%$, and $10 \%$ levels, respectively.

\begin{tabular}{lcccc}
\hline \hline & $(1)$ & $(2)$ & $(3)$ & $(3)$ \\
& & $\Delta \operatorname{Ln}(\mathrm{SBL})$ & \\
\hline Ln(Distance) & $-0.018^{* * *}$ & $-0.010^{* * *}$ & -0.000 & $0.007^{* * *}$ \\
& $(0.001)$ & $(0.001)$ & $(0.001)$ & $(0.001)$ \\
Ln(Distance) $\times$ HP-Filtered Real GDP & $0.051^{* * *}$ & $0.053^{* * *}$ & $0.055^{* * *}$ & $0.058^{* * *}$ \\
& $(0.001)$ & $(0.001)$ & $(0.001)$ & $(0.001)$ \\
\hline Observations & 2298039 & 1860071 & 1361031 & 1029940 \\
Adjusted $R^{2}$ & 0.032 & 0.038 & 0.043 & 0.045 \\
Sample & $>10$ & $>20$ & $>50$ & $>100$ \\
Baseline Controls & Yes & Yes & Yes & Yes \\
Bank Fixed Effects & Yes & Yes & Yes & Yes \\
County-Year Fixed Effects & Yes & Yes & Yes & Yes \\
\hline \hline
\end{tabular}




\section{Table IA.7: Distance and Small Business Lending: Small Agricultural Loans}

The dependent variable, $\Delta L n$ (Small Farm Loans), is the change in the natural logarithm of one plus the total amount of small farm loans originated by a bank to small farms located in a county during a calendar year. HP-Filtered Real GDP is the standardized HP-filtered percent change in the real GDP. Real GDP series is obtained from the Federal Reserve Economic Data (FRED) website of the Federal Reserve of St. Louis. $\Delta$ Ln (Unempld Rate) is standardized log difference in the US annual unemployment rate. The unemployment rate series is obtained from the FRED website. Spreads is the standardized net percentage of domestic banks increasing spreads of loan rates over banks' cost of funds to small firms obtained from the FRED website. Ln(Distance) is the natural logarithm of the minimum distance between the bank's branches and the county centroid. The specification includes borrower county-by-year and bank fixed-effects as well as baseline controls for natural logarithm of Total Assets, Share of Commercial \& Real Estate Loans, Share of Residential Loans, and Share of Commercial \& Industrial Loans. Standard errors are presented in parentheses, and are clustered at the level of the county. $* * *, * *$, and $*$, represent statistical significance at $1 \%, 5 \%$, and $10 \%$ levels, respectively.

\begin{tabular}{|c|c|c|c|}
\hline & (1) & $(2)$ & (3) \\
\hline & \multicolumn{3}{|c|}{$\Delta \operatorname{Ln}($ Small Farm Loans $)$} \\
\hline Ln(Distance) & $\begin{array}{l}-0.018^{* * *} \\
(0.001)\end{array}$ & $\begin{array}{l}-0.018^{* * *} \\
(0.001)\end{array}$ & $\begin{array}{l}-0.018^{* * *} \\
(0.001)\end{array}$ \\
\hline Ln $($ Distance $) \times$ HP-Filtered Real GDP & $\begin{array}{l}0.019 * * * \\
(0.001)\end{array}$ & & \\
\hline $\operatorname{Ln}($ Distance $) \times \Delta \operatorname{Ln}($ Unempld Rate $)$ & & $\begin{array}{l}-0.004^{* * *} \\
(0.001)\end{array}$ & \\
\hline $\operatorname{Ln}($ Distance $) \times$ Spreads & & & $\begin{array}{l}-0.009^{* * *} \\
(0.001)\end{array}$ \\
\hline Observations & 1563898 & 1563898 & 1563898 \\
\hline Adjusted $R^{2}$ & 0.011 & 0.011 & 0.011 \\
\hline Baseline Controls & Yes & Yes & Yes \\
\hline Bank Fixed Effects & Yes & Yes & Yes \\
\hline Borrower County-Year Fixed Effects & Yes & Yes & Yes \\
\hline
\end{tabular}




\section{Table IA.8: Distance and Small Business Administration Lending: Business Cycle Indicators}

The dependent variable, $\Delta L n(S B L)$, is the change in the natural logarithm of one plus the total amount of small business administration loans originated by a bank to small businesses located in a county during a calendar year. HP-Filtered Real GDP is the standardized HP-filtered percent change in the real GDP. Real GDP series is obtained from the Federal Reserve Economic Data (FRED) website of the Federal Reserve of St. Louis. $\Delta$ Ln (Unempld Rate) is standardized log difference in the US annual unemployment rate. The unemployment rate series is obtained from the FRED website. Spreads is the standardized net percentage of domestic banks increasing spreads of loan rates over banks' cost of funds to small firms obtained from the FRED website. Ln(Distance) represents the logarithm of the average distance between the headquarters of a bank and its borrowers in the county. Standard errors are presented in parentheses, and are clustered at the level of the county. ${ }^{* *},{ }^{* *}$, and $*$, represent statistical significance at $1 \%, 5 \%$, and $10 \%$ levels, respectively.

\begin{tabular}{lccc}
\hline \hline & $(1)$ & $(2)$ & $(3)$ \\
& \multicolumn{3}{c}{$\Delta$ Ln(SBL) } \\
\hline Ln(Distance) & -0.000 & -0.001 & -0.002 \\
& $(0.003)$ & $(0.003)$ & $(0.003)$ \\
Ln(Distance) $\times$ HP-Filtered Real GDP & $0.016^{* * *}$ & \\
& $(0.002)$ & & \\
Ln(Distance) $\times \Delta \operatorname{Ln}($ Unempld Rate $)$ & & $-0.023^{* * *}$ \\
& & $(0.002)$ & $-0.022^{* * *}$ \\
$\operatorname{Ln}($ Distance $) \times$ Spreads & & & $(0.002)$ \\
\hline Observations & 104742 & 104742 & 104742 \\
Adjusted $R^{2}$ & 0.021 & 0.022 & 0.022 \\
Baseline Controls & Yes & Yes & Yes \\
Bank Fixed Effects & Yes & Yes & Yes \\
Borrower County-Year Fixed Effects & Yes & Yes & Yes \\
\hline \hline
\end{tabular}




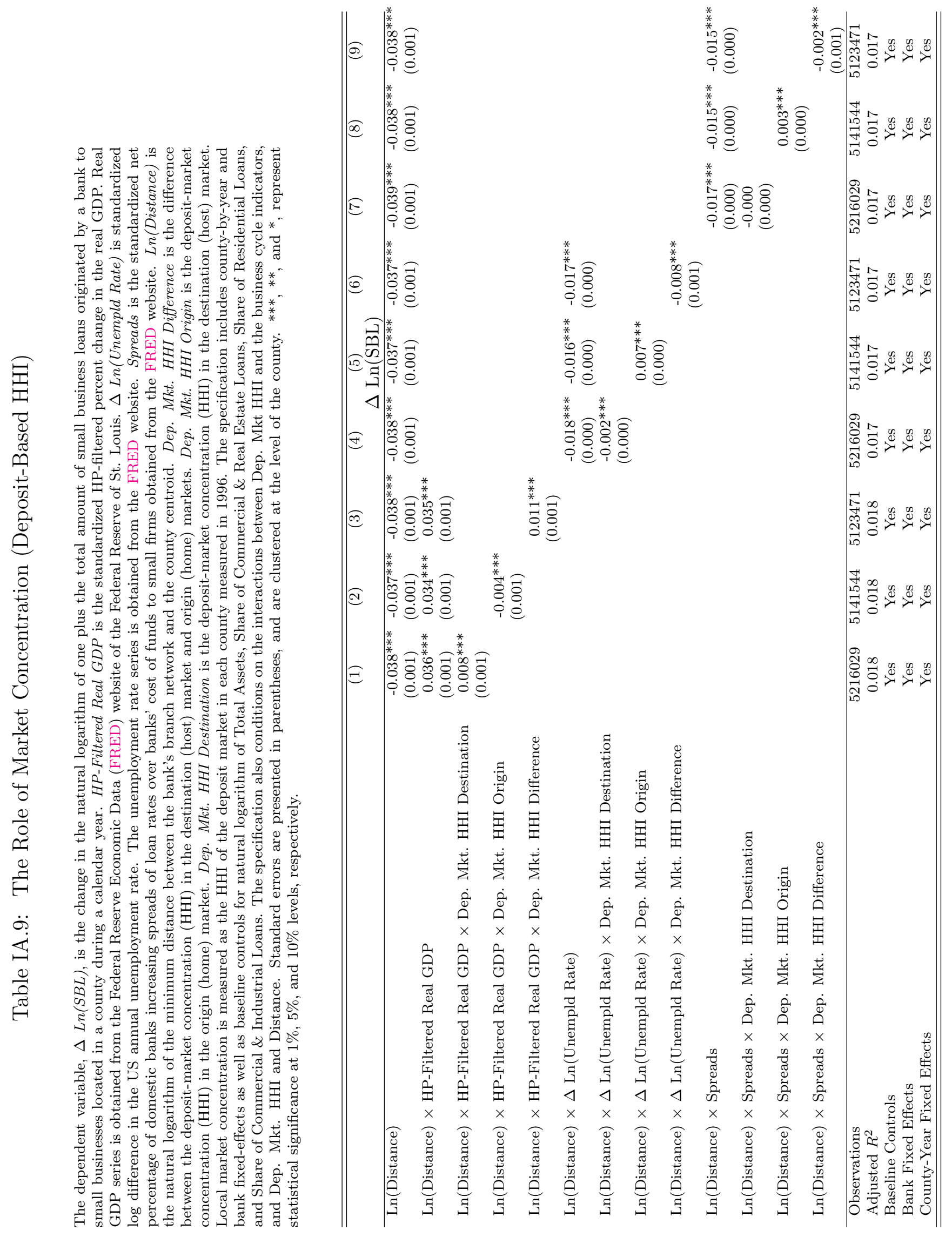




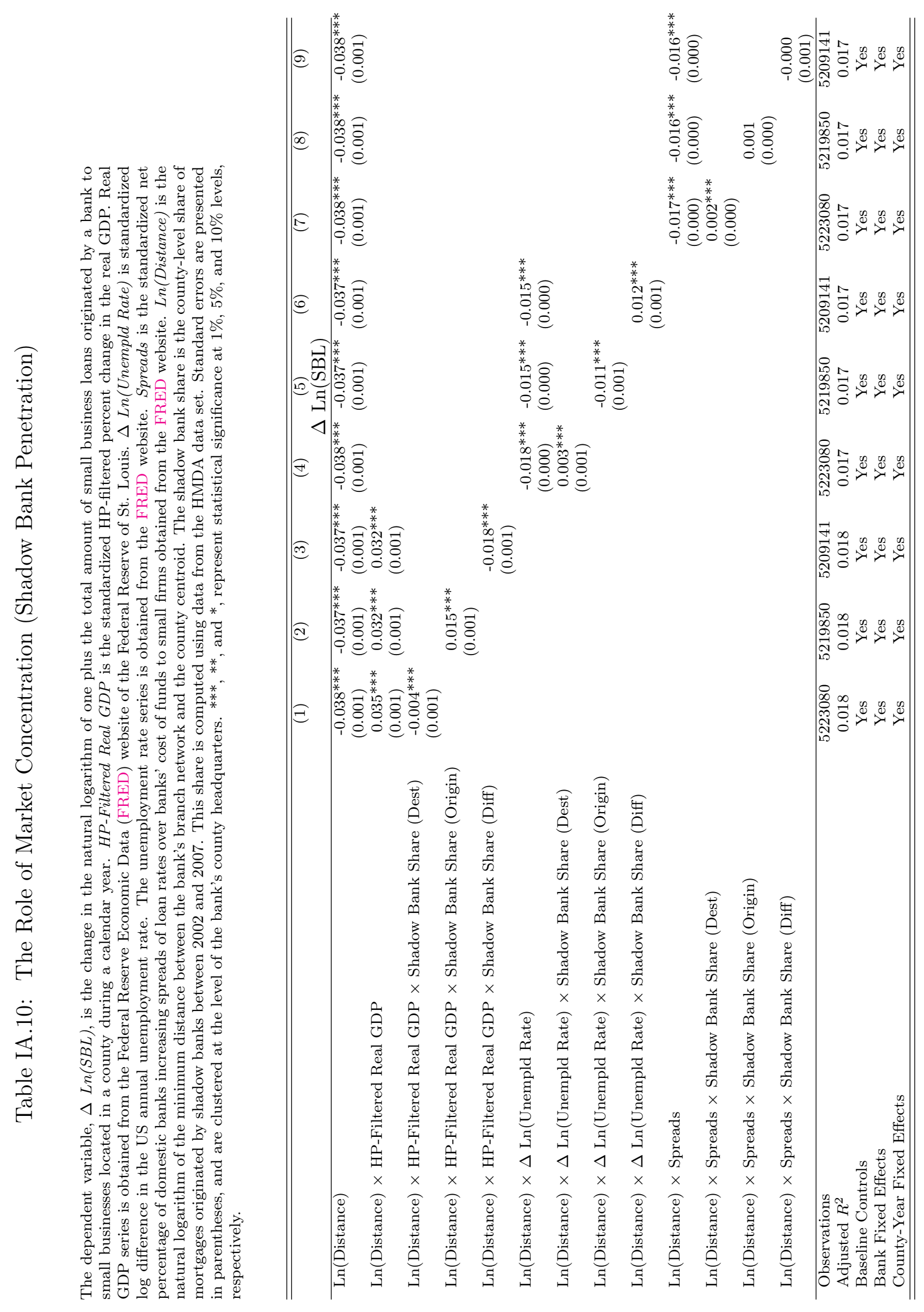




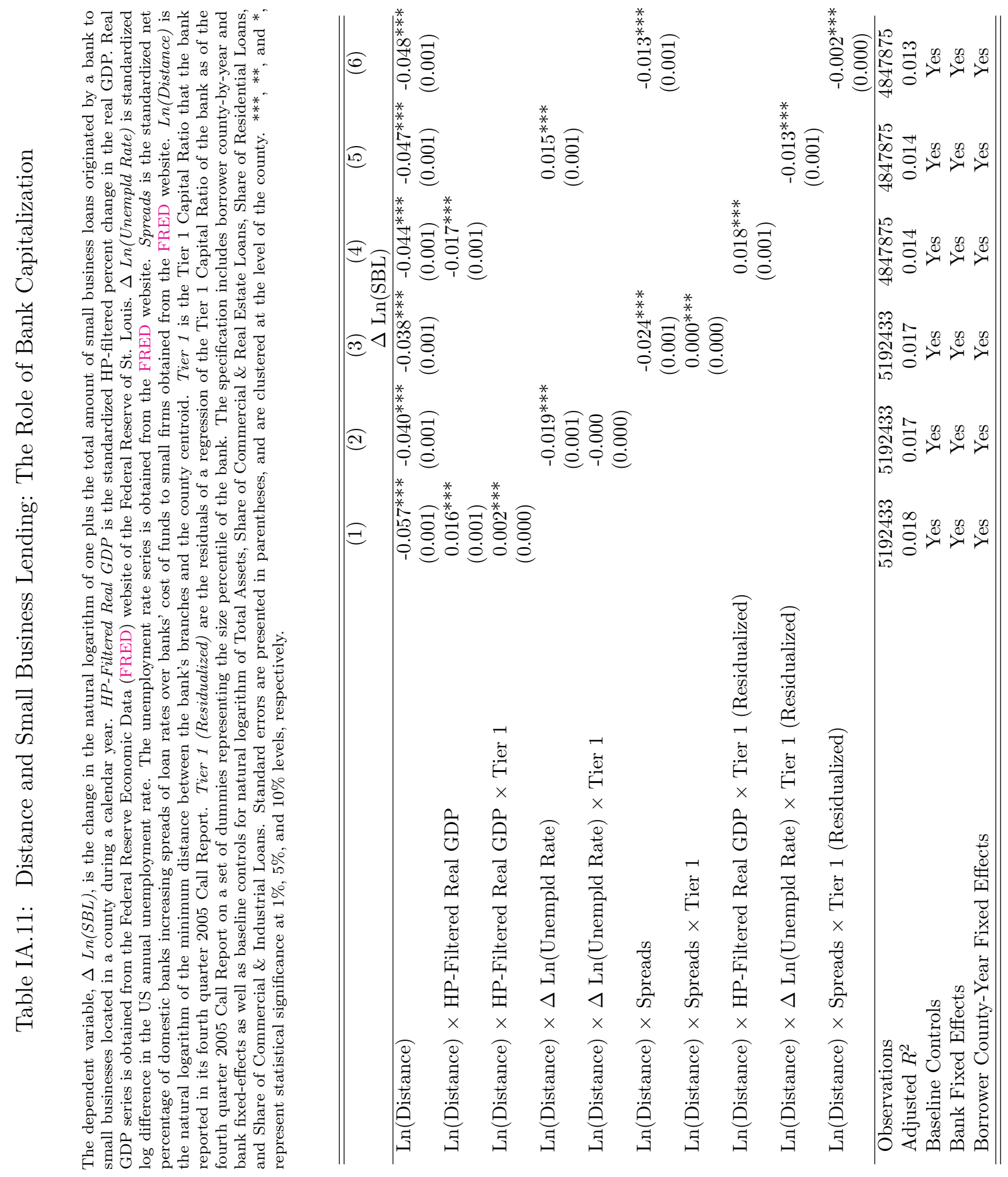




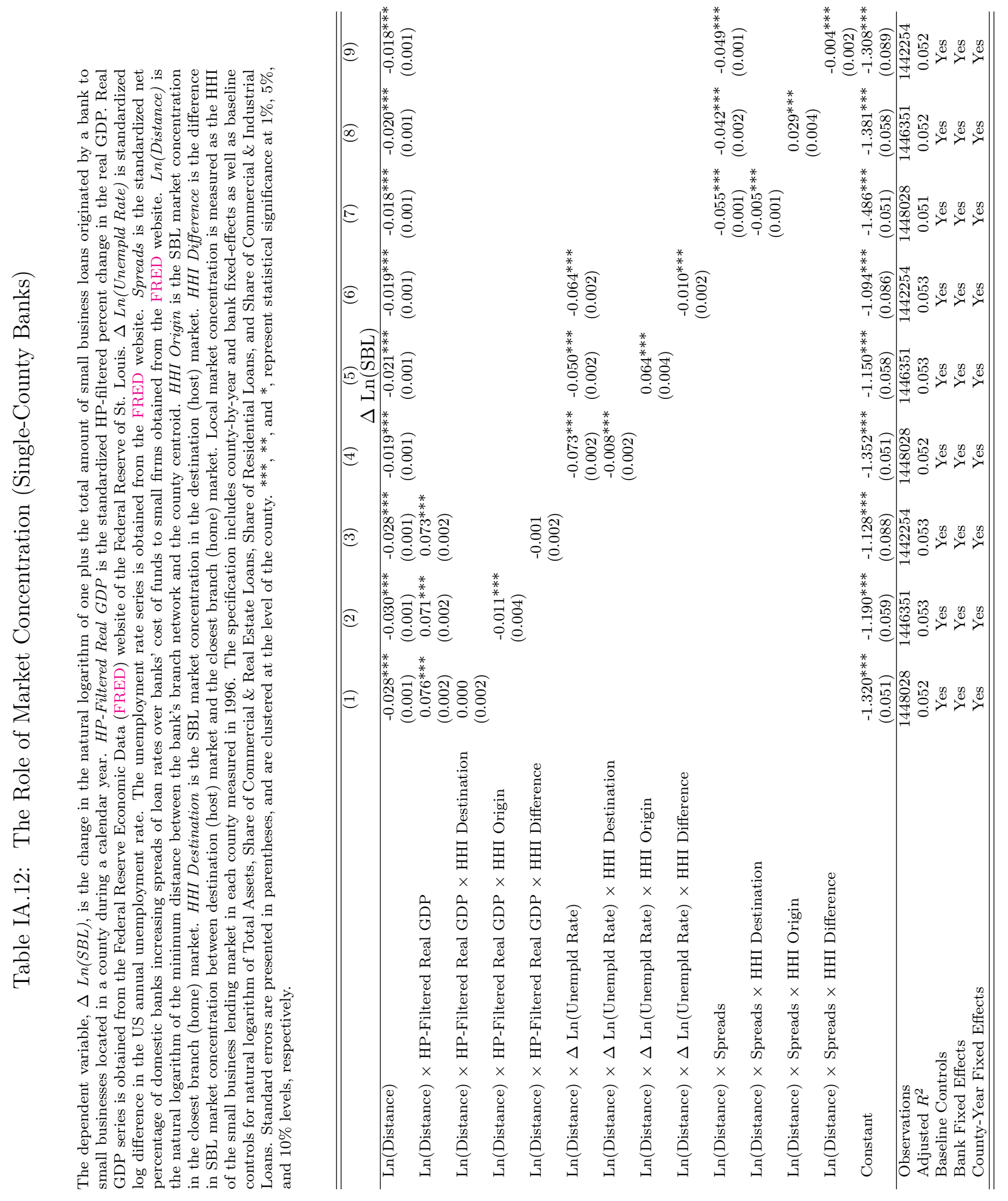




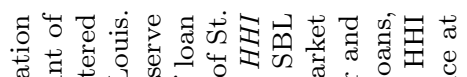

蛋

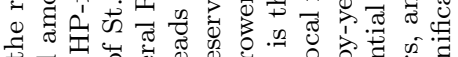

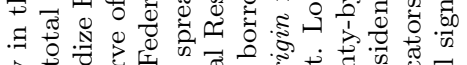

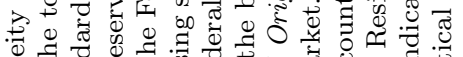

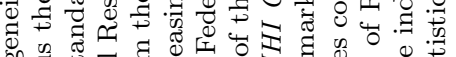

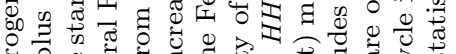

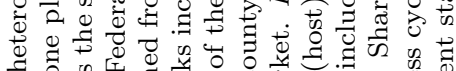

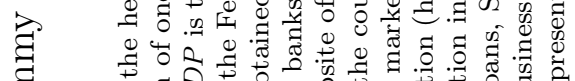

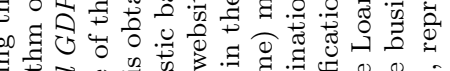

苟菏

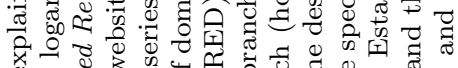

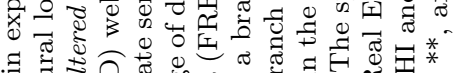

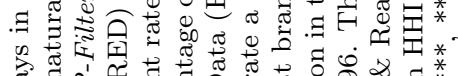

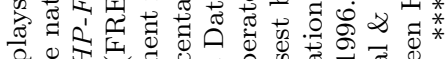

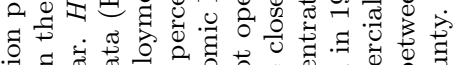

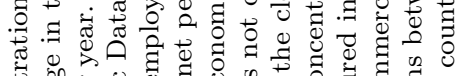

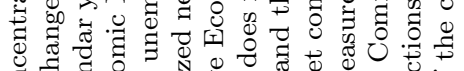

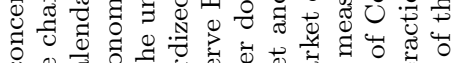

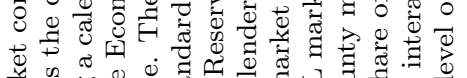

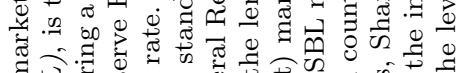

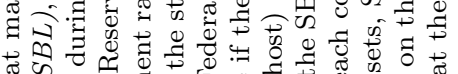

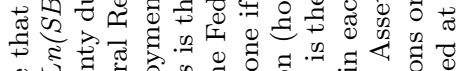

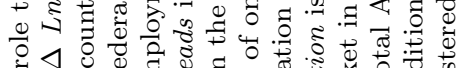

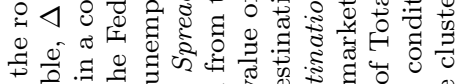

o.

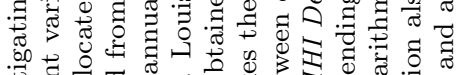

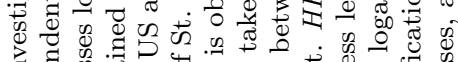

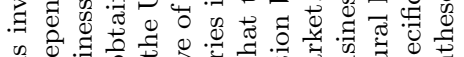

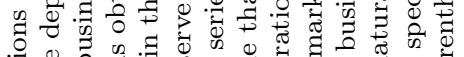

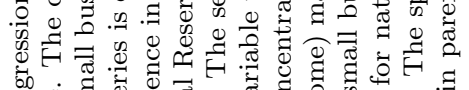

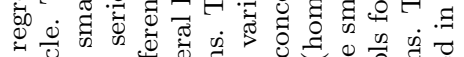

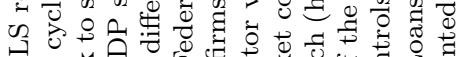

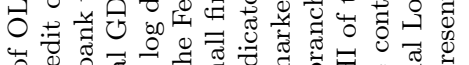

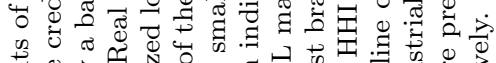

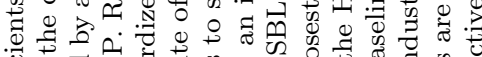

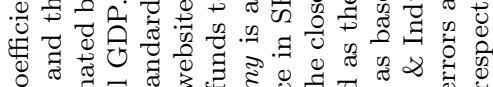

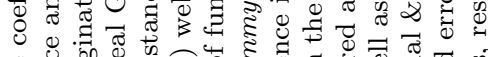

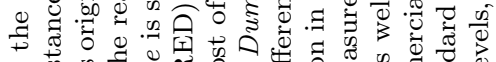

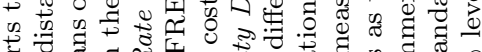

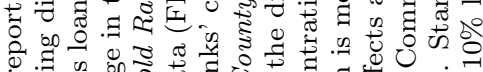

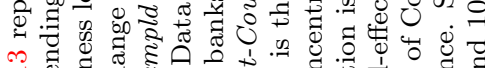

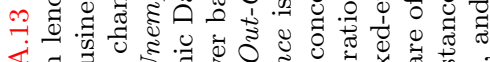

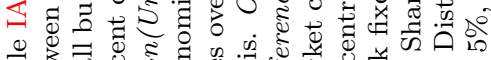

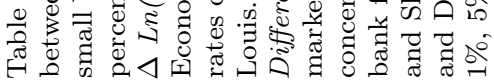

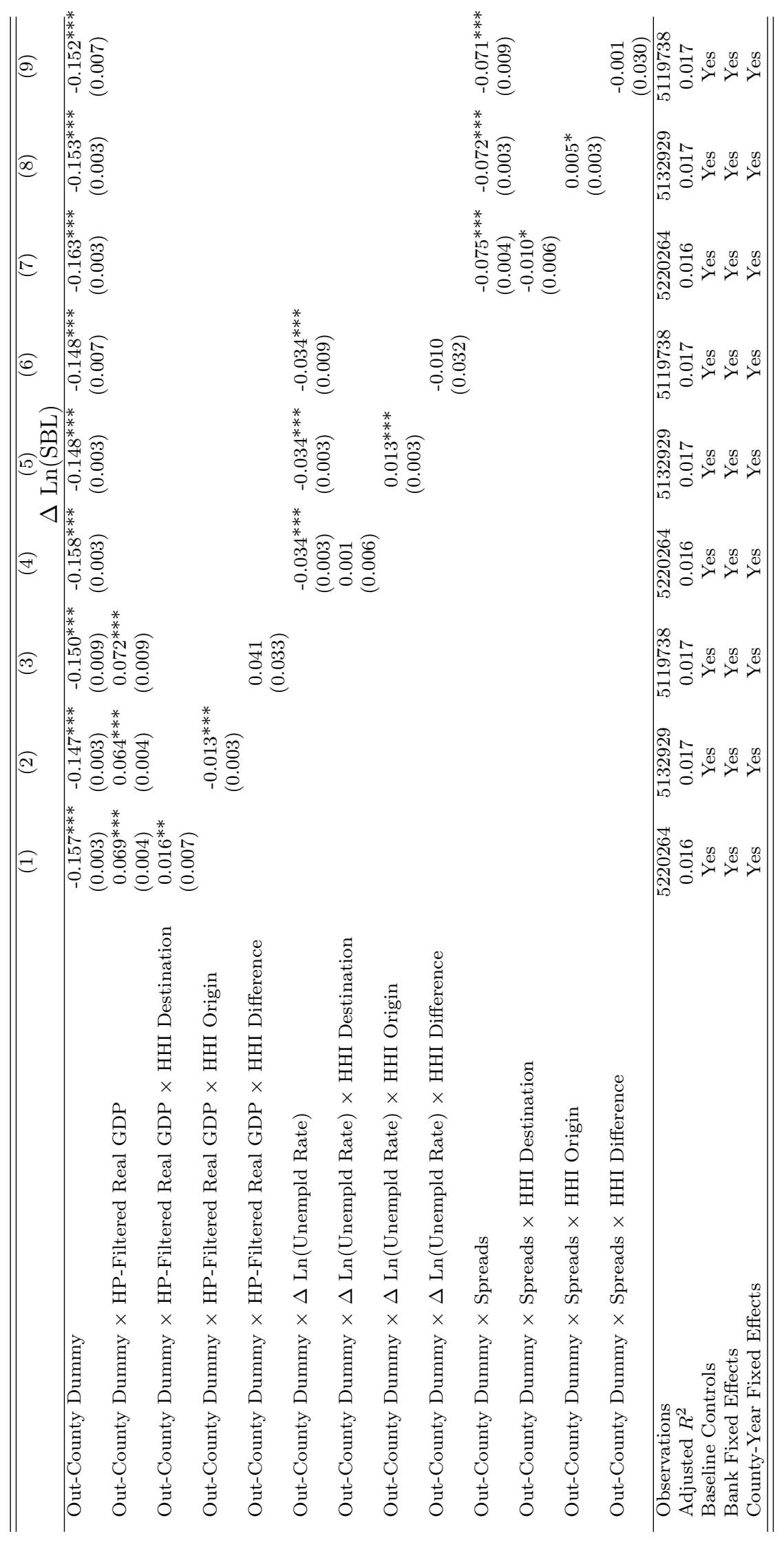

